IGOR MACHADO DA SILVEIRA

\title{
AVALIAÇÃO DA MOBILIDADE URBANA COM ÊNFASE NA CONDIÇÃO DA ACIDENTALIDADE DO USUÁRIO VULNERÁVEL
}

\begin{abstract}
Dissertação apresentada ao Departamento de Transportes (STT/EESC/USP), como parte dos requisitos para a obtenção do título de Mestre em Engenharia Civil, Pós-graduação em Engenharia de Transportes. Área de Concentração: Planejamento e Operação de Sistemas de Transporte.
\end{abstract}

Orientador: Prof. Titular Antônio Clóvis Pinto Ferraz 


\section{AUTORIZO A REPRODUÇÃO E DIVULGAÇÃO TOTAL OU PARCIAL DESTE TRABALHO, POR QUALQUER MEIO CONVENCIONAL OU ELETRÔNICO, PARA FINS DE ESTUDO E PESQUISA, DESDE QUE CITADA A FONTE}

Ficha Catalográfica preparada para Seção de Tratamento da

\begin{tabular}{|c|c|}
\hline \multirow[t]{3}{*}{ M587a } & $\begin{array}{l}\text { Silveira, Igor Machado da } \\
\text { AVALIAÇÃO DA MOBILIDADE URBANA COM } \\
\text { ÊNFASE NA CONDIÇÃO DO USUÁRIO VULNERÁVEL / } \\
\text { Igor Machado da Silveira; orientador Antônio Clovis Pinto } \\
\text { Ferraz. São Carlos, } 2016 .\end{array}$ \\
\hline & $\begin{array}{l}\text { Dissertação (Mestrado) - Programa de Pós-Graduação } \\
\text { em Engenharia de Transportes e Área de Concentração em } \\
\text { Planejamento e Operação de Sistemas de Transporte - Escola } \\
\text { de Engenharia de São Carlos da Universidade de São Paulo }\end{array}$ \\
\hline & $\begin{array}{l}\text { 1. Mobilidade Urbana. 2. Desenvolvimento Urbano. } 3 . \\
\text { Usuário Vulnerável. 4. Usuário Não Vulnerável. } 5 . \\
\text { Transporte Público. 6. Acidentalidade Urbana. } 7 . \\
\text { Segurança Viária. 8. Acessibilidade. I. Título. }\end{array}$ \\
\hline
\end{tabular}

Informação do Serviço de Biblioteca - EESC/USP 
"Nunca perca a fé na humanidade, pois ela é como um oceano.

Só porque existem algumas gotas de água suja nele, não quer dizer que ele esteja sujo por completo."

Mahatma Gandhi 

Candidato: Engenheiro IGOR MACHADO DA SILVEIRA.

Título da dissertação: "Avalioçđo da mobilidade urbana com ênfase na condiç̋o da acidentalidade do usuário vulneróvel".

Data da defesa: 15/04/2016.

Comissāo Julgadora:

Prof. Titular Antonio Clóvls Pinto Ferraz

(Orientador)

[Escola de Engenharia de Sôo Carios/EESC)

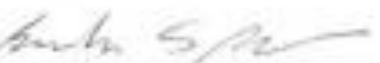

Resultado:

Axwmo

Profa. Dra. Bárbara Stolte Bezerra

(Universidade Estadual Paulista "Júlio de Mesquita Filho"/UNEST - Bauru)

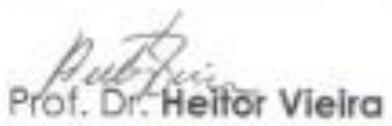

(Universidade Federal do Rio Grande/UFRG)

Coordenador do Programa de Pós-Graduaçåo em Engenharia de Transportes:

Prot. Associado Paulo Cesar Lima Segantine

Presidente da Comissão de Pós-Graduação:

Prof. Associado Paulo Cesar Lima Segantine 



\section{AGRADECIMENTOS}

Ao Prof. Dr. Antônio Clovis Pinto Ferraz (Coca), pela orientação.

Ao Prof. Dr. Heitor Vieira, pela incansável ajuda e inúmeras contribuições para o desenvolvimento do trabalho.

A todos colegas e amigos da pós-graduação, em especial Angélica Meireles de Oliveira, Diego Camargo, Miguel Castillo e Murilo Castanho.

À amiga e revisora Andrise Buchweitz Klug, que também me incentivou Abuscar o mestrado.

A CAPES, pela bolsa de estudos concedida. 



\section{RESUMO}

\section{SILVEIRA, I. M. Avaliação da Mobilidade Urbana com Ênfase na Condição da}

Acidentalidade do Usuário Vulnerável. São Carlos, 2016. Dissertação (Mestrado) - Escola de Engenharia de São Carlos, Universidade de São Paulo.

Atualmente vive-se uma mudança de paradigma no planejamento dos transportes: o ser humano volta a ser o centro da tomada de decisões e o automóvel fica em segundo plano. Para que isso ocorra, são necessárias ferramentas confiáveis as quais avaliem a situação atual das cidades para que sejam traçadas metas no sentido de melhorar a vida da população. A mobilidade urbana sustentável busca a melhoria do transporte baseada no tripé social, ambiental e econômico. Esse trabalho busca avaliar a condição de segurança do usuário vulnerável (sem carenagem protetora) em relação ao usuário não vulnerável (com carenagem), buscando avaliar fatores como o modo escolhido para justificar a segurança do usuário. Apesar da mudança de paradigma, as intervenções urbanas continuam voltadas ao transporte individual, assim o usuário de transporte público de má qualidade migra para outros modos, o que causa o aumento do risco relativo do usuário vulnerável. Um dos fatores que influenciam muito para essa migração é o tempo de viagem, significativamente maior para o usuário do transporte público.

Palavras - chave: Acidentes de Trânsito. Usuários Vulneráveis. Mudança de Paradigma. Planejamento Urbano. Transporte Público. Motocicleta. Tempo de Viagem. 



\begin{abstract}
SILVEIRA, I. M. Urban Mobility Evaluation Focused in Vulnerable User Accidentality

Condition. São Carlos, 2016. Dissertação (Mestrado) - Escola de Engenharia de São Carlos, Universidade de São Paulo.
\end{abstract}

The present time is known by its change in the paradigm of the transport planning. The human being is once again the main point of the decision making and the automotive vehicles are transcending to a second plan. This demands trust tools to evaluate the real situation of the cities so that real goals to improve people's life get drawn. The sustainable urban mobility seeks to improve the transport based on the social, environmental and economic tripod. This essay seeks to evaluate the vulnerable user safety condition (without external protection), against the non vulnerable user (with external protection), such as estimate the choice of the user justifying its safety. Besides the change of the scenario, the urban interventions are still focused in the individual transportation kind, what means that the poor conditions of the transit makes users migrate increasing the relative risk for the vulnerable users. One factor that influences the migration is the time spent on the traveling, which is a lot longer for the user of transit.

Palavras - chave: Trafic crash. Vulnerable User. Paradigma Change. Urban Planing. Transit. Motorcicle. Time Travel. 



\section{SUMÁRIO}

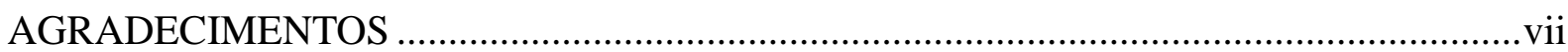

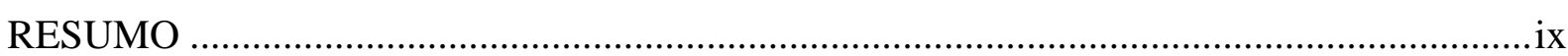

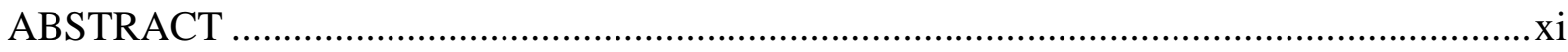

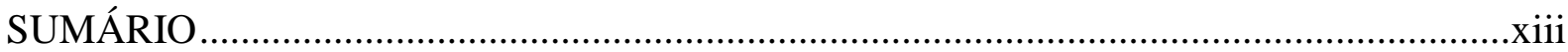

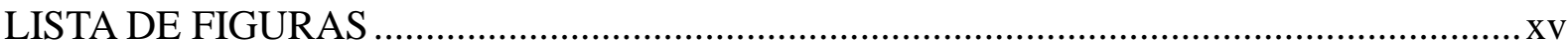

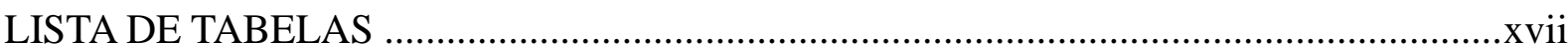

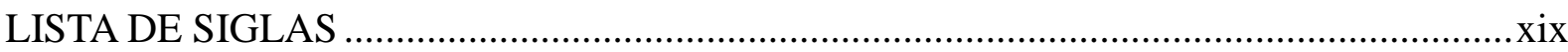

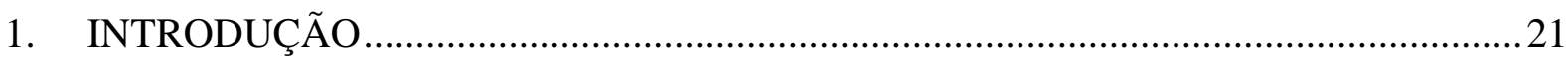

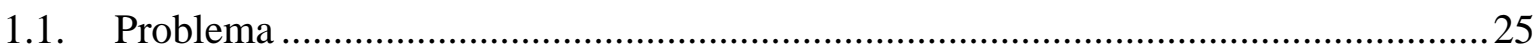

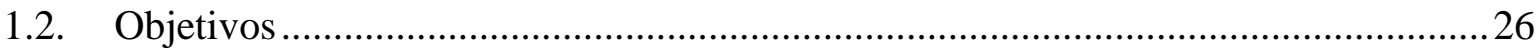

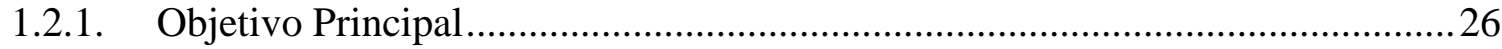

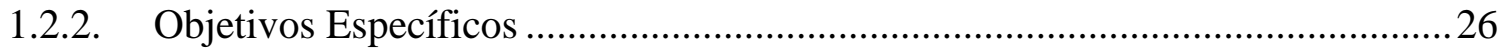

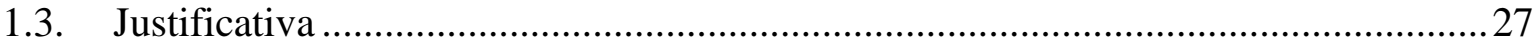

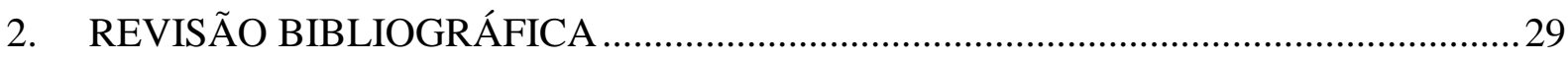

2.1. Mobilidade Urbana Sustentável ............................................................................. 29

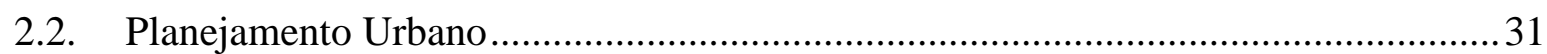

2.3. Os modos de transporte, seus produtos e externalidades ........................................ 35

2.3.1. Consumo de Energia, Emissão de Gases, Custo e Uso do Solo ........................... 35

2.3.2. A interferência da variável tempo na escolha modal ........................................... 37

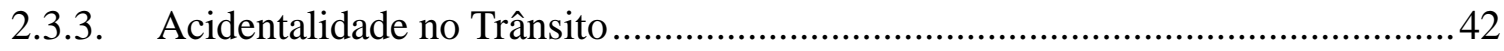

2.3.4. Bancos de dados de acidentes de trânsito ............................................................. 51

2.4. Indicadores de Mobilidade Sustentável .......................................................................52

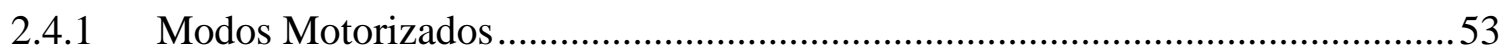

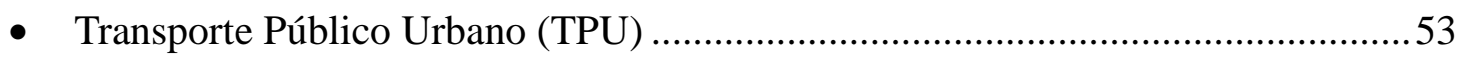

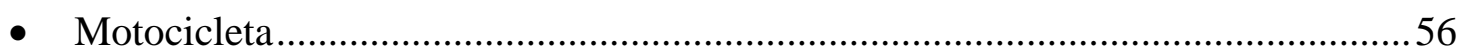

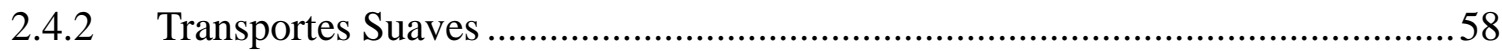

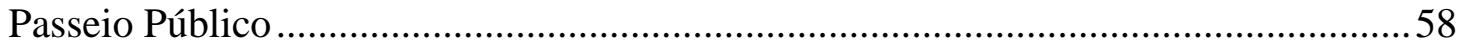

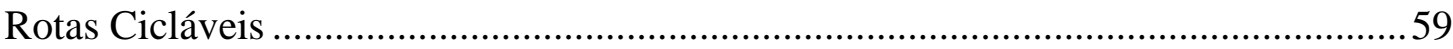

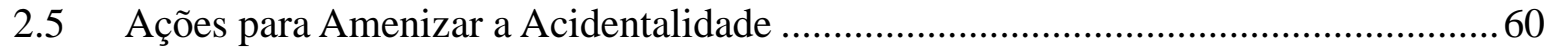

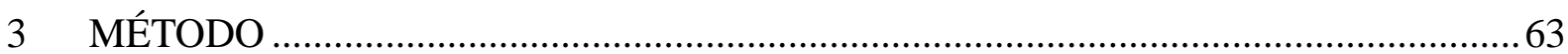

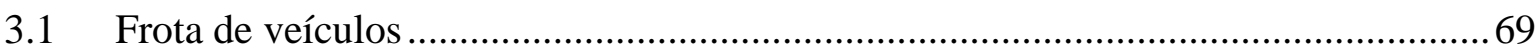

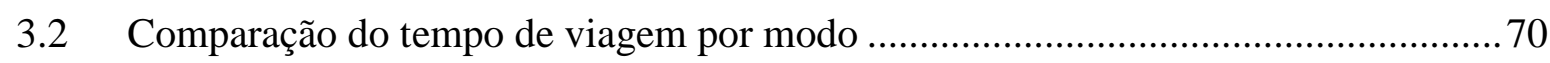

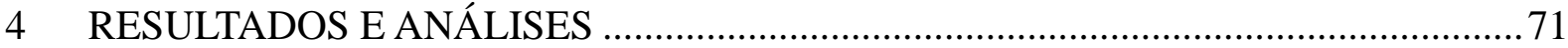

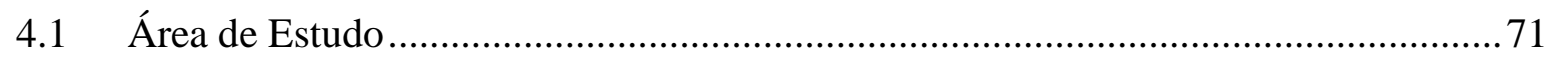

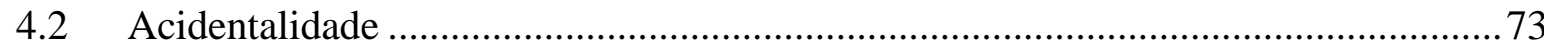




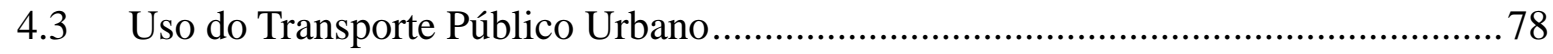

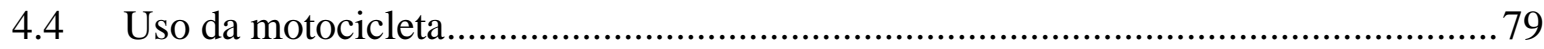

4.5 Comparação do Tempo de Viagem ...................................................................... 81

4.6 Esforço do poder público para diminuir a acidentalidade ...................................... 82

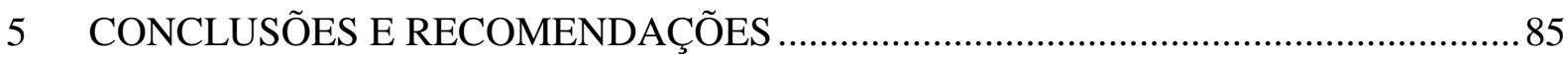

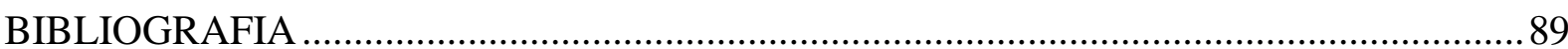




\section{LISTA DE FIGURAS}

Figura 1 - Estimativa da participação do transporte público no total de viagens 22

Figura 2 - Percentual de pessoas que pode se deslocar por cada modo. A pé (a); por bicicleta(b); por transporte coletivo (c); por motocicleta (d) e, por veículo próprio (e) ...........30

Figura 3 - Uso do Solo por diferentes modos 37

Figura 4 - Comparação do índice de mortes por bilhão de quilômetros percorridos no Brasil (2008) e em outros países (2009) 44

Figura 5 - Objetivo da Década de Ações pela Segurança no Trânsito...................................... 45

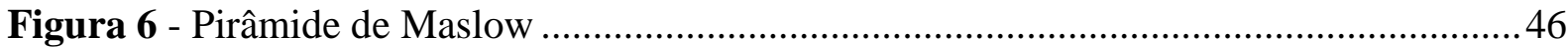

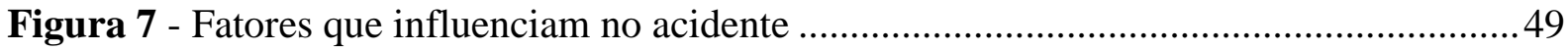

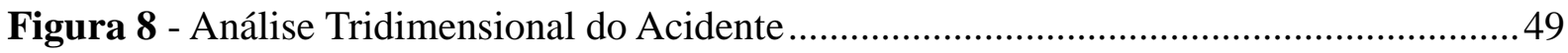

Figura 9 - Pessoas por hora em uma faixa de $3,5 \mathrm{~m}$ de largura.............................................54

Figura 10 - Evolução da frota de motocicletas e automóveis no Brasil ..................................56

Figura 11 - Crescimento anual da frota em relação ao ano anterior .....................................57

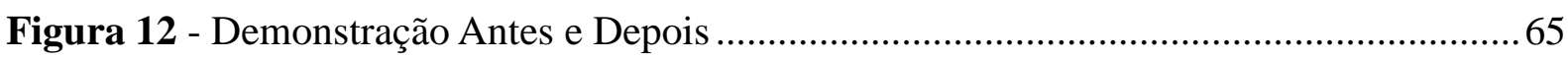

Figura 13 - TABNET DATASUS - Pesquisa e filtros dos dados .......................................... 67

Figura 14 - TABNET DATASUS - Pesquisa e filtros dos dados .......................................... 68

Figura 15 - Evolução da Frota no Município de Caxias do Sul ...............................................69

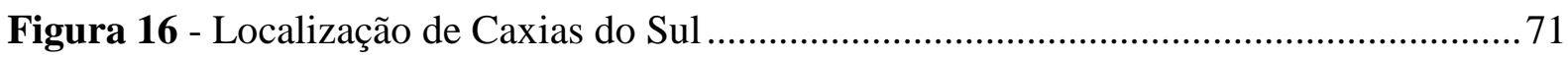

Figura 17 - Delimitação do perímetro urbano e Rodovias que influenciam nos deslocamento

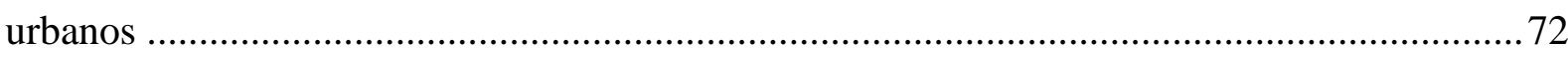

Figura 18 - Óbitos devido acidentes de trânsito na cidade de Caxias do Sul entre os anos de

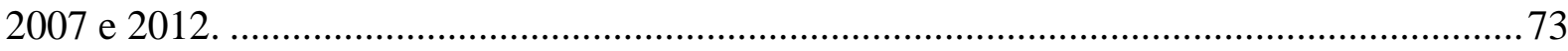

Figura 19 - Índice de óbitos/100.000 veículos em Caxias do Sul .........................................76

Figura 20 - Evolução dos óbitos em Caxias do Sul.................................................................. 77

Figura 21 - Crescimento da Frota de Veículos Automotores em Caxias do Sul......................79

Figura 22 - Crescimento Percentual Anual Acumulado da Frota de Veículos na Cidade de Caxias do Sul 80 



\section{LISTA DE TABELAS}

Tabela 1 - Probabilidade de morte de acordo com a velocidade do impacto.............................35

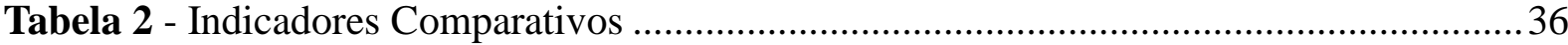

Tabela 3 - Comparação de indicadores para diferentes modos de transporte.......................... 40

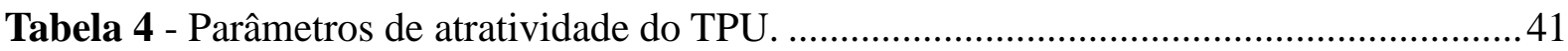

Tabela 5 - Vítimas de acidentes de trânsito por modo, Caxias do Sul RS, 2012 .....................50

Tabela 6 - Comparação do Risco Relativo entre diferentes modos de transporte ....................55

Tabela 7 - Parâmetros mínimos para passeios públicos..............................................................59

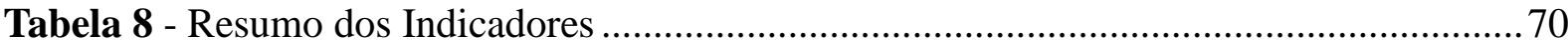

Tabela 9 - Rodovias que cruzam a cidade de Caxias do Sul.................................................... 72

Tabela 10 - Classificação dos óbitos em UV e UNV ………................................................. 74

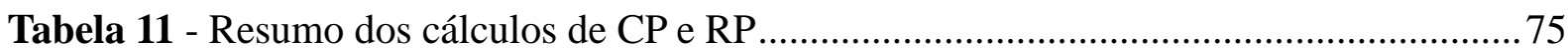

Tabela 12 - Cálculo da Prevalência Pedestres/UNV .............................................................. 76

Tabela 13 - Cálculo da Prevalência Ciclistas/UNV ................................................................ 76

Tabela 14 - Razão de Prevalência Motociclistas/UNV .......................................................... 76

Tabela 15 - Dados do Tranporte Público Urbano em Caxias do Sul ..................................... 78

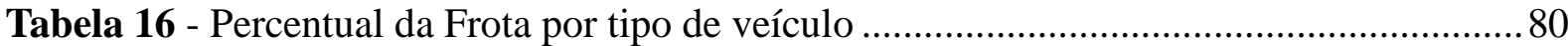

Tabela 17 - Comparação tempo de viagem entre ônibus, carro e motocicleta ........................ 81

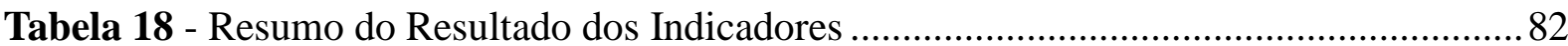





\section{LISTA DE SIGLAS}

ABNT - ASSOCIAÇÃO BRASILEIRAS DE NORMAS TÉCNICAS

BRT - BUS RAPID TRANSIT

CTB - CÓDIGO DE TRÂNSITO BRASILEIRO

DENATRAN - DEPARTAMENTO NACIONAL DE TRÂNSITO

DETRAN - DEPARTAMENTO ESTADUAL DE TRÂNSITO

EUA - ESTADOS UNIDOS DA AMÉRICA

HCM - HIGHWAY CAPACITY MANUAL

HSM - HIGHWAY SAFETY MANUAL

IBGE - INSTITUTO BRASILEIRO DE GEOGRAFIA E ESTATÍSTICA

IPKe - ÍNDICE DE PASSAGEIRO QUILÔMETRO EQUIVALENTE

PIB - PRODUTO INTERNO BRUTO

SMTTM - SECRETARIA MUNICIPAL DE TRÂNSITO, TRANSPORTES E MOBILIDADE

OMS - ORGANIZAÇÃO MUNDIAL DA SAÚDE

TOD - TRANSIT-ORIENTED DEVELOPMENT

TPU - TRANSPORTE PÚBLICO URBANO

UNV - USUÁRIO NÃO VULNERÁVEL

USP - UNIVERSIDADE DE SÃO PAULO

UV - USUÁRIO VULNERÁVEL 


\section{INTRODUÇÃO}

O crescimento da cidade sempre esteve atrelado à capacidade de deslocamento do ser humano e enquanto ele usou apenas sua própria capacidade de locomoção ficou limitado às distâncias viáveis para caminhadas. Ao se tornar sedentário, o homem passou a construir cidades para a dimensão humana, nas quais todos os deslocamentos podiam ser realizados a pé (GEHL, 2012). À medida que o homem começou a utilizar veículos com tração animal, começou também a mudar a forma das cidades. O Império Romano, famoso pelas suas estradas pavimentadas que eram a base do seu comércio e do seu deslocamento de tropas, possuía problemas de trânsito na área urbana. Conflitos entre diferentes modos e congestionamentos deram origem a leis de trânsito e implantação de sinalização, proibindo, por exemplo, a circulação de carroças no centro, em determinados horários do dia.

Até 1600, o transporte era próprio, realizado a pé, montado em animal ou por carruagem, o que era privilégio dos ricos. O primeiro transporte público surgiu nesta data por meio de carruagens de aluguel em Londres e Paris. Em 1826, em Nantes, França, a palavra Omnibus (que significa: para todos, em latim) foi usada pela primeira vez. Esse veículo, mais longo que as carruagens da época, foi inventando na Inglaterra uns anos mais cedo, mas o nome com o qual se popularizou veio da França. Impulsionados pela Revolução Industrial, vários veículos do tipo Omnibus passaram a operar em diversas cidades do mundo (FERRAZ e TORRES, 2004).

O transporte coletivo prosperou e logo surgiram novas tecnologias, como o bonde sobre trilhos puxado por tração animal. Posteriormente, ele evoluiu para o bonde elétrico. Com a invenção do motor a diesel ocorreu a evolução do Omnibus para o Ônibus com tração mecânica. Junto com o ônibus surgiu o automóvel, que, aos poucos, foi ganhando espaço devido ao status, à liberdade e ao conforto que representava. A produção em série popularizou o mesmo, o que resultou em transferência de investimentos direcionados ao transporte coletivo para o automóvel. Nos EUA, a motorização aumentou tanto que, em 1935, o uso do automóvel superou o do transporte coletivo. Essa tendência se repetiu em diversos países desenvolvidos após a segunda guerra e vem acontecendo nos países em desenvolvimento até hoje. No caso do Brasil o gráfico abaixo mostra que, em 2010, o uso do transporte individual se igualou ao uso do transporte coletivo. 


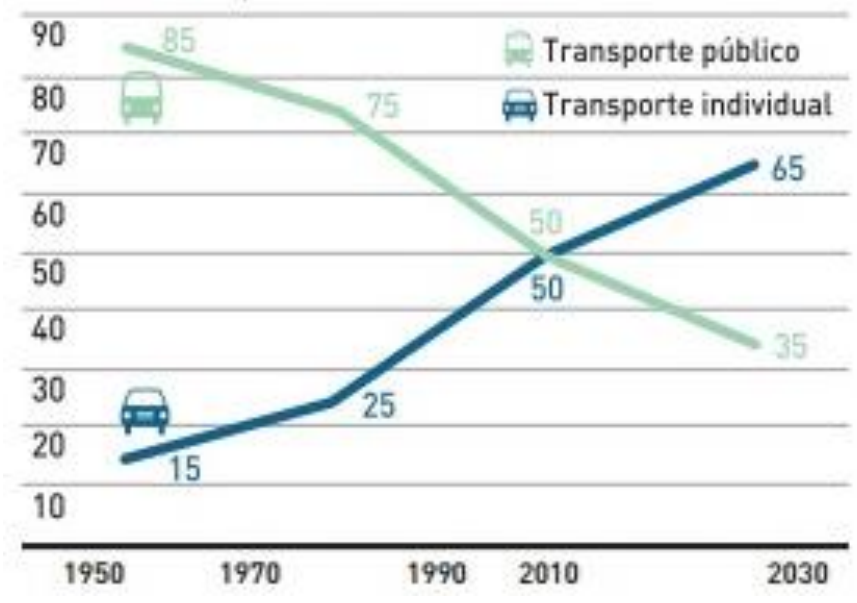

Figura 1 - Estimativa da participação do transporte público no total de viagens. (FONTE: FETRANSPOR)

Os deslocamentos suaves atingiram um novo patamar com os modelos antecessores da bicicleta, surgidos por volta de 1600. Porém, os primeiros modelos da bicicleta parecida com a que conhecemos hoje começaram a circular por volta de 1839 como uma importante alternativa de baixo custo, liberdade de horário e tempo. Porém, por volta de 1930, o seu uso começou a diminuir em decorrência do aumento do uso do automóvel (GTZ, 2009).

O automóvel, desde o seu surgimento, passou a influenciar a qualidade da vida urbana. Ainda no século XIX, foi registrado o primeiro acidente fatal com veículo motorizado, em Londres, nascido de um conflito entre um pedestre (usuário vulnerável) e um automóvel. Outros acidentes seguiram ocorrendo sem que isso afetasse a imagem do novo modo de transporte. $\mathrm{O}$ automóvel, na verdade, foi considerado como um salto para segurança em relação aos veículos de tração animal e humana e, com a sua massificação, passou a ser o balizador do desenho urbano da maioria das cidades até o final do século XX (EVANS, 2004).

A variável tempo é fundamental na vida do ser humano e o aumento da velocidade dos meios de transporte propiciou o crescimento das cidades, já que os deslocamentos maiores podiam ser percorridos com o mesmo consumo de tempo. No entanto, o transporte individual demanda espaço de forma insaciável e investimentos de capital intensivo em infraestrutura. Apesar da baixa produtividade do automóvel, o qual carrega em média 1,3 pessoas por viagem, ele passou a ser o paradigma para o planejamento urbano ao invés do ser humano. Perderam-se os espaços de lazer e as áreas verdes, diminuíram-se as interações entre pessoas e alguns lugares foram marginalizados como, por exemplo, os espaços livres debaixo de viadutos, onde há baixo fluxo de pessoas. Parques, locais de recreação têm dado espaço para o 
automóvel, diminuindo a qualidade de vida, fragmentando espaços públicos e bairros pobres, criando barreiras para os modos tracionados com força humana (ANTP e SPTRANS, 2012; JACOBS, 1961).

Esse modelo de planejamento voltado para o uso do automóvel começou no início do século XX e intensificou-se após a $2^{\mathrm{a}}$ Guerra, perdurando até hoje. Uma das primeiras críticas desse modelo foi a jornalista americana Jane Jacobs que lançou em 1961 o livro "Morte e vida das grandes cidades". Ela vivia o dia a dia da transformação em NY, vendo as áreas de convivência desaparecerem, dando espaço para vias expressas dentro da cidade. $\mathrm{O}$ arquiteto alemão Max Schwitalla fala que, atualmente, as cidades são consideradas os lugares mais importantes do mundo devido à concentração de pessoas. Porém, a maioria dos designers urbanísticos tenta criar lugares aonde os carros tenham seu espaço (ANTP, 2015).

O maior paradoxo disso é que, já nos anos 1930, o sistema rodoviarista mostrava sua insustentabilidade. Robert Moses, engenheiro americano, projetou uma avançada malha de rodovias no estado de Nova Iorque, hipoteticamente, com capacidade para mais de 20 anos. No entanto, bem antes do prazo, em apenas 18 meses, o sistema estava saturado. Em seguida, ampliaram-na novamente e o sistema saturou em um prazo ainda menor. Quanto mais espaço é oferecido ao automóvel, mais automóveis são atraídos em um ciclo irracional e extremamente dispendioso (ANTP, 2012; GTZ, 2009).

Diante do aumento das distâncias viajadas nas cidades, os modos motorizados são fundamentais para proporcionar a mobilidade necessária às pessoas. A falta de planejamento e investimento em transporte coletivo levou as pessoas a utilizá-lo apenas por necessidade, porém, quando conseguem migrar para outros modos, o fazem. A primeira opção de modo de transporte para a maior parte da população é o automóvel. Apesar disso, nos últimos anos, a motocicleta está ganhando mercado por causa do baixo custo de aquisição e manutenção e por proporcionar benefícios equivalentes ao automóvel. Essa tendência proporciona a inclusão social de pessoas de baixa renda, mas, em contrapartida, implica no aumento de acidentes com agravos e mortes (VIEIRA, BASTOS, et al., 2007).

Aos poucos, pensadores e estudiosos perceberam que o uso demasiado do transporte individual motorizado acarretava em diversos problemas de caráter econômico, social e ambiental (GTZ, 2009). As cidades se tornaram segmentadas e desumanizadas, distanciando e 
isolando os cidadãos. Dia a dia se tornava evidente a necessidade de apontar um novo paradigma, não só de mobilidade, mas também de planejamento urbano integrado.

É importante ressaltar que a desumanização do meio urbano é, antes de tudo, uma questão de escala, a qual faz com que os nossos equipamentos urbanos sejam desenhados para o veículo do homem e não para o homem. No caso, o automóvel e outros veículos rodoviários têm orientado o desenvolvimento urbano, incluindo uma série de riscos e penalidades ao deslocamento do pedestre ou de seus modos suaves de deslocamento. Neste ambiente hostil é esperado que estes usuários vulneráveis enfrentem agravos a sua saúde e qualidade de vida, além de um impacto substancial na sua mobilidade (GEHL, 2012).

Academicamente, a troca de paradigma vem se materializando por uma preocupação maior com os agravos ocorridos da interação entre dois grupos de usuários, antagônicos em relação à vulnerabilidade dentro do sistema de trânsito. Alguns trabalhos recentes referem-se aos conflitos entre usuários, segmentados em usuários vulneráveis (UV) e usuários nãovulneráveis (UNV). Os UV são aqueles que não possuem uma carenagem a protegê-los. Entre os UV podem-se incluir, além de pedestres, ciclistas, motociclistas, cadeirantes, skatistas, e outros usuários de veículos sobre rodas, de tração humana. Os UNV são os que possuem uma carenagem protetora, como, por exemplo, automóveis, caminhões e ônibus (OTTE, JÄNSCH e HAASPER, 2012; PRATO, GITELMAN e BEKHOR, 2012; WEI e LOVEGROVE, 2012).

A partir do século XX, o planejamento urbano tomou como referência o automóvel e não mais o ser humano. Passaram-se anos, muitos exemplos mostraram a insustentabilidade do transporte individual e uma nova maneira de planejar a cidade vem sendo discutida. Nos últimos anos, o foco do transporte vem sendo o transporte coletivo e os modos suaves. As iniciativas e mudanças, que começaram nos países desenvolvidos, agora chegam a países em desenvolvimento como o Brasil. Diversos projetos e programas de políticas públicas incentivam o uso de transportes sustentáveis.

Essa mudança de paradigma já estava prevista no CTB desde 1997, onde o art. 29 inciso $2^{\circ}$ diz:

Respeitadas as normas de circulação e conduta estabelecidas neste artigo, em ordem decrescente, os veículos de maior porte serão sempre responsáveis pela segurança 
dos menores, os motorizados pelos não motorizados e, juntos, pela incolumidade dos pedestres (CTB, 1997).

Apesar de a lei já ser favorável ao usuário vulnerável, é necessário que ela seja materializada através de ações concretas, como o uso de ferramentas mais eficazes para acompanhar a efetividade de contramedidas ou o impacto de externalidades no processo de tomada de decisão. No deslocamento, o uso de Transporte Público e Modos Suaves caracteriza uma vida mais racional (uso do solo, equilíbrio econômico e segurança) e saudável. Para a melhoria da mobilidade de forma sustentável, são necessários parâmetros de comparação para traçar objetivos a serem alcançados.

\subsection{Problema}

A complexidade dos problemas a se enfrentar no planejamento urbano no Brasil, a escassez de recursos e a urgência das medidas a serem tomadas tornam necessário o uso de alguma metodologia que permita auxiliar na avaliação de sistemas de mobilidade urbana. A dinâmica do caos urbano começa com o aumento da demanda e a ausência de um sistema de transportes eficiente. Na busca de soluções, a princípio, e se dispuser de recursos, o usuário usa o automóvel ou a motocicleta. O resultado é que quanto mais automóveis mais congestionamentos e mais atropelamentos. A moto, devido a sua vulnerabilidade, tem um efeito mais desastroso, dividindo com os automóveis os agravos provocados aos ciclistas e pedestres, além de expor seus usuários a um risco muito elevado (OLIVEIRA, VIEIRA, et al., 2011).

Uma solução lógica para o problema seria a oferta de um transporte público capaz de proporcionar uma viagem rápida, em relação ao automóvel, confiável e pouco dispendioso. Deste modo, haveria mais eficiência no aproveitamento do espaço urbano e menos congestionamentos e vítimas no trânsito. Essa ideia de retirar os usuários dos modos individuais motorizados oferecendo-lhes uma forma de mobilidade mais segura, por meio de um serviço público, é, na prática, a redução da exposição a um elemento de risco elevado. Assim, cada indivíduo transferido terá uma viagem mais segura e deixará de impor risco aos demais usuários, principalmente aos mais vulneráveis. A transferência dos usuários para o transporte coletivo viabiliza o mesmo, aumentando a probabilidade de que ele possa oferecer um serviço cada vez mais atrativo, com um feedback positivo. 
Um sistema de transporte público viável começa em calçadas com bom índice de caminhabilidade e complementado por rotas cicláveis e acessíveis. Este aspecto fica evidenciado na metodologia TOD (Transit-Oriented Development) que propõe revitalizar áreas urbanas degradadas escolhendo locais adequados para implantação das estações nas quais são prioridades a mobilidade interna, a zona e a microacessibilidade. O tratamento do entorno das estações visa melhorar a habitabilidade com a oferta de calçadas adequadas, rotas cicláveis, e áreas de lazer, e, com isso, atrair mais usuários potenciais para a estação e garantir a viabilidade do mesmo.

\subsection{Objetivos}

\subsubsection{Objetivo Principal}

Um estudo do risco relativo experimentado por Usuários Vulneráveis (UV) em relação aos não vulneráveis (UNV) e sua relação com a matriz de escolha modal.

As condições de risco relativo para descrever a qualidade de desenvolvimento e/ou sustentabilidade dos sistemas de mobilidades são baseadas na prevalência de agravos entre Usuários Vulneráveis (UV) em relação aos ocorridos entre Usuários Não Vulneráveis (UNV).

\subsubsection{Objetivos Específicos}

Para auxiliar no estudo do risco relativo será feita a análise de indicadores que expliquem o resultado encontrado na situação de segurança. Serão analisados indicadores que colaboram para a mobilidade sustentável, como:

- Grau de utilização do TPU em relação ao transporte individual e a sua influência na acidentalidade;

- Grau de utilização da Motocicleta em relação a matriz geral de transportes urbanos e a sua influência na acidentalidade;

- Comparação do tempo de deslocamento entre diferentes modos no meio urbano. 


\subsection{Justificativa}

Os problemas de mobilidade urbana atuais são o resultado do planejamento voltado ao automóvel no último século. As externalidades causadas por este modelo afetam a população de maneira que o poder público necessita agir para diminuí-las.

Esse trabalho propõe avaliar a evolução da condição de segurança do usuário vulnerável no sistema de transportes em relação ao desenvolvimento urbano. Essa forma de avaliação pode auxiliar na tomada de decisão dos órgãos gestores visando melhorar a segurança do elo mais fraco do sistema de mobilidade, na mesma linha de pensamento do planejamento urbano sustentável. 


\section{REVISÃO BIBLIOGRÁFICA}

\subsection{Mobilidade Urbana Sustentável}

A palavra mobilidade vem do Latim, Mobilis, e significa o que pode ser movido, deslocado. A capacidade de mobilidade está ligada a todas as atividades humanas, e envolve deslocamentos para trabalho, estudo, lazer, consumo, quando se tratando do deslocamento de pessoas e suas interações. Para os bens de consumo, a mobilidade está ligada aos deslocamentos de matéria prima e distribuição dos produtos. A mobilidade inclui a infraestrutura necessária para o transporte e os impactos causados por sua interação (EUROFORUM, 2007).

O princípio da mobilidade é o de que quanto mais viagens diárias melhor, pois isso reflete no acesso das pessoas a cidade. O Ministério das Cidades (2004) através da Política Nacional de Mobilidade Urbana Sustentável define:

A mobilidade urbana é um atributo das cidades e se refere à facilidade de deslocamento de pessoas e bens no espaço urbano. Tais deslocamentos são feitos através de veículos, vias e toda a infraestrutura (vias, calçadas, etc.)... É o resultado da interação entre os deslocamentos de pessoas e bens com a cidade.

A mobilidade envolve qualquer modo de transporte. Sendo assim, todos são importantes e devem receber a devida atenção. Alguns fatores podem induzir, restringir e, até mesmo, condicionar a mobilidade. Esses fatores individuais são, por exemplo, faixa etária, classe social, deficiência física e/ou mental. Diante das capacidades individuais, que às vezes geram restrições de uso, segue na Figura 2, resumo de um estudo que tentou identificar a proporção da população que pode usar cada modo (MINISTÉRIO DA CIDADES, 2006; MACHADO, 2010). 


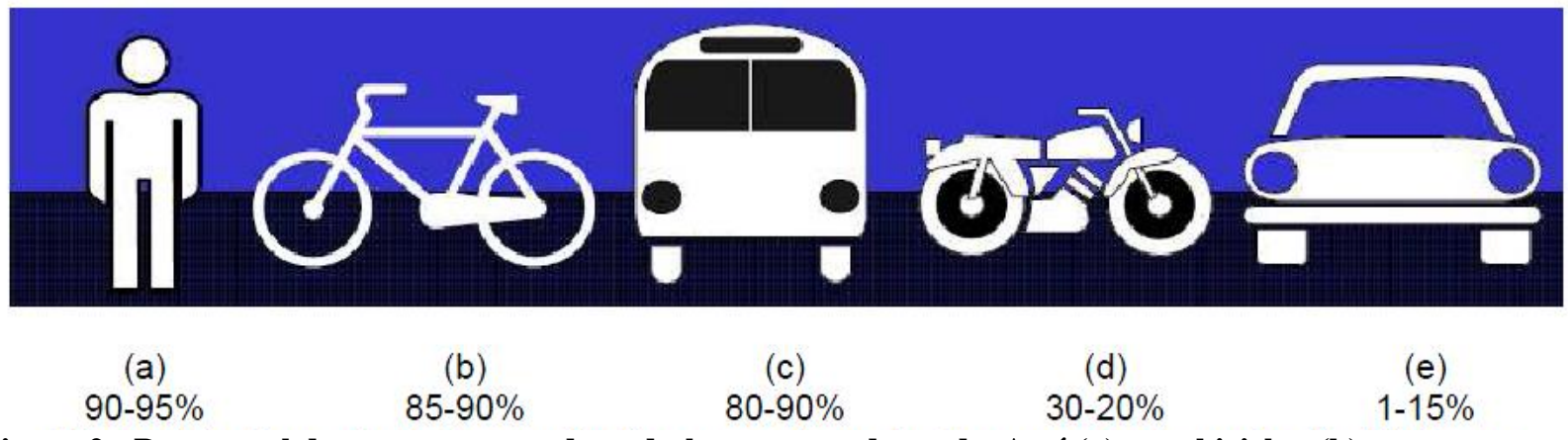

Figura 2 - Percentual de pessoas que pode se deslocar por cada modo. A pé (a); por bicicleta(b); por transporte coletivo (c); por motocicleta (d) e, por veículo próprio (e). (Fonte: Machado, 2010)

Os dados apresentados na Figura 2 parecem estar um tanto quanto subestimados para os dias atuais. Apesar disso, é importante perceber que os modos suaves e coletivos abrangem um percentual da população muito maior que os motorizados individuais, seja por limitações físicas ou mentais como por limitações financeiras.

Para alcançar a mobilidade desejada e proporcionar à população direitos previstos na Constituição Federal, os governos investem milhões em intervenções urbanas, porém, na maior parte das vezes, os benefícios alcançados são menores do que as externalidades geradas. O modelo de planejamento atual, baseado nos veículos individuais, alcança seu objetivo parcialmente, pois leva as pessoas aos seus destinos, porém não da forma que gostariam. Os principais problemas urbanos encontrados atualmente são: congestionamentos, conflitos entre diferentes modos de transportes, redução na segurança para usuários vulneráveis, eliminação de parte de áreas verdes, que visam ampliar espaços para circulação e estacionamentos de veículos, aumento no número de acidentes de trânsito e aumento nos níveis de poluição do ar e sonora (ASSUNÇÃO, 2012).

Considerando o panorama urbano como um todo, o conceito de sustentabilidade surge com o intuito de mudar o paradigma do desenvolvimento urbano, amenizando as externalidades de um planejamento que não utiliza a escala humana. Diversos autores definem o desenvolvimento sustentável como a capacidade em atender as necessidades da geração atual, sem comprometer as necessidades das gerações futuras (PLUME, 2003; EUROFORUM,2007; GTZ, 2009; CAMPOS, 2011). O desenvolvimento sustentável se apoia no tripé social, ambiental e econômico. Buscando equilibrar esses três parâmetros, a mobilidade sustentável visa promover o deslocamento de forma a integrar a sociedade, 
utilizando de forma racional as matérias primas e de maneira a serem economicamente viáveis e seguras (TRANSPLUS, 2002).

\subsection{Planejamento Urbano}

O planejamento em transportes visa proporcionar mobilidade à população de forma satisfatória, eficiente e saudável. Ao longo do tempo, os conceitos de planejamento ideal mudaram, mas o objetivo fundamental não. Para atingir os objetivos da mobilidade é necessário lutar contra as externalidades ligadas ao deslocamento, sejam elas decorrentes de um erro de escala ou da má aplicação dos recursos disponíveis.

Mello (1981) fala que até 1950, as soluções adotadas em transporte eram praticamente sem planejamento com medidas empíricas tentando satisfazer os desejos da população por deslocamento. Atualmente, os profissionais responsáveis pelo planejamento e gerenciamento do transporte urbano, em cidades de pequeno e médio porte, ainda relutam em usar métodos científicos, baseados em mobilidade sustentável, apesar de certas funções terem sido delegadas ao município pela legislação vigente (BRASIL, 2012). A falta de know-how em mobilidade faz com que "amadores" busquem meios de solucionar os problemas em transportes, mas sem um método científico como base.

É de extrema importância a coleta de dados para estimar as externalidades provocadas no trânsito e, assim, poder discutir soluções. Se a sociedade tem um problema, temos que avaliar o tamanho dele e criar ações para amenizá-lo. Os dados são vitais para qualquer projeto de engenharia, estes podem ser tabulados e analisados, assim teremos justificativas técnicas para abordar problemas recorrentes. No Brasil, alguns dados já são coletados por Postos Médicos Legais, Delegacias de Trânsito e Órgãos Municipais, Estaduais e Federais de Trânsito. Muitas vezes, esse processo de coleta para por aí; não são feitas estatísticas sobre os dados e, o pior, há uma imensa dificuldade em ter acesso a esses dados por parte dos pesquisadores. Embora tenha havido uma substancial evolução no processo de coleta e análise de dados dos acidentes de trânsito, vê-se ainda uma dificuldade na obtenção destes dados (TRINDADE, 1988; VIEIRA, 1999; BASTOS, 2011)

Se tratando de segurança viária, por exemplo, para uma tomada de decisão com base técnica, 
necessita-se do registro dos acidentes para constituição de um banco de dados que permita o processamento e a análise das informações de acidentes de trânsito em determinada região. A quantificação dos acidentes envolve diversos órgãos do governo e são dados que devem ser coletados por pessoas treinadas devido à quantidade de informação. Essas informações são quantificadas em relação ao número de acidentes, mortos e feridos, além de criar índices associados a dados de população, frota de veículos, volume de tráfego, extensão de via, quilômetro rodado. Os índices permitem avaliar a dimensão da acidentalidade em determinado espaço geográfico comparando a outras causas de mortalidade e também a outros espaços geográficos (BASTOS, 2011; FERRAZ, RAIA JUNIOR, et al., 2012).

Para que a melhoria na mobilidade urbana aconteça, precisamos de ferramentas de auxílio para o planejamento, assim é possível prever medidas e cenários futuros, elaborar políticas e direcionar investimentos. Os indicadores também são usados para avaliar situações, ou seja, quando padronizados tornam-se medidas de desempenho. Atualmente, existem alguns índices de mobilidade sustentável que são baseados em diversos indicadores, por muitas vezes a obtenção dos mesmos ser demorada e até mesmo inviável, além de possuírem dificuldade em ser calibrados e alimentados. Pensando nas dificuldades encontradas no setor público e baseando-se na teoria da Navalha de Ockham ${ }^{1}$, busca-se um índice de mobilidade sustentável com menos fatores, apenas os necessários, mas que consiga demostrar a situação atual da mobilidade urbana sustentável.

Apesar dessa cultura empírica persistir e o planejamento voltado para o transporte individual estar enraizado na sociedade, essa conscientização por parte dos governos e da população começa a aparecer. Mesmo que singela, essa troca de paradigma já está sendo vista no Brasil. O Ministério das Cidades iniciou um projeto de incentivo à mobilidade urbana sustentável através da exigência de planos de mobilidade urbana em cidades com mais de 20.000 mil habitantes. Esse plano tem como objetivo priorizar o uso de transporte coletivo e modos não motorizados valorizando assim o ser humano em primeiro lugar. Além disso, os municípios que não elaborarem esse plano no prazo previsto ficam impossibilitados de receber investimentos federais no setor (BRASIL, 2012).

A ideia do plano de mobilidade é mais ampla do que apenas um estudo e planejamento em transportes. O plano de mobilidade tem o intuito de integrar outros planos de diretrizes das cidades, como planos diretores e código de posturas. Essa integração tem o objetivo de que o 
trânsito seja pensado a nível local inclusive, ou seja, que as cidades possuam múltiplos centros, sem necessitar o movimento pendular, bairro/centro e centro/bairro nos períodos de pico. Bairros autossuficientes auxiliam no aumento do uso de modos não motorizados, tornando os locais mais habitáveis e melhorando a qualidade de vida (BRASIL, 2012; GEHL, 2012).

Pensando nesse novo conceito, o Transit-Oriented Development (TOD) se encaixa perfeitamente nessa mudança de paradigma, pois ele é um modelo de planejamento que se baseia em um Desenvolvimento Orientado ao Transporte Público, no qual o intuito é direcionar investimentos do transporte público para tratar o entorno das estações, principalmente em relação a microacessibilidade, potencializando a atração de usuários da região. Estudos de Arrington (2012) mostram que aplicando o conceito de TOD, estações individuais de transporte público sobre trilhos tiveram aumento do número de viagens de $20 \%$ a $40 \%$ e considerando o aumento a nível regional esse foi de $5 \%$. Tal conceito pode ser estendido para o transporte público de ônibus considerando estações com maior movimento, como é o caso de terminais de integração ou estações de BRT. O aumento do uso do TPU é uma consequência dos benefícios da implementação do TOD, que atrai o usuário pela facilidade de acesso ao transporte público.

Outro ponto interessante é que o TOD favorece o preenchimento dos vazios urbanos, tornando o entorno da estação um local com uma habitabilidade mais atraente, aumentando a qualidade de vida. Essa revitalização do entorno das estações gera benefícios como o aumento da circulação de pessoas no local, o tornando mais humano. Acompanhado disto, os pequenos comércios prosperam atraindo mais pessoas. Essa preocupação com o entorno das estações exige um investimento tão baixo se comparado à investimentos em saúde ou em vias para veículos que, independentemente do grau de desenvolvimento e capacidade financeira da cidade, é possível realizar essas melhorias (GEHL, 2012)

Já foram citados diversos benefícios da aplicação do TOD, mas o tratamento da microacessibilidade no entorno de estações aumenta a segurança do UV, pois a abrangência de tratamento ocorre num raio de 400 a 800 metros das paradas do transporte público, facilitando acessos e proporcionando maior habitabilidade. O TOD introduz no planejamento e desenvolvimento urbano os mesmos conceitos que embasam ao Novo Urbanismo, Crescimento Inteligente e Movimento de Comunidades Habitáveis, correntes progressistas 
que buscam a reumanização das cidades. Seguem algumas diretrizes nas quais esses modelos de planejamento se baseiam:

1. Densidade de desenvolvimento entre média e alta;

2. Mix de usos do solo, horizontal ou vertical;

3. Design e paisagismo das ruas compacto e orientado ao pedestre;

4. Projeto de edificações e orientação à rua que permita trânsito e acesso fácil aos pedestres;

5. Uma rede de ruas conectadas sem cul-de-sacs;

6. Um sistema de parques e áreas abertas.

É visível como essa nova maneira de planejar cumpre com seu objetivo de tornar as cidades mais humanas, priorizando a segurança do UV e garantindo a sua mobilidade pela viabilização e qualificação do TPU (ARRINGTON, 2012).

Além de planejar o espaço físico, atualizações tecnológicas que tornem o sistema mais eficiente fazem parte do planejamento e geram resultados positivos na melhoria do sistema de transporte. Um exemplo deste tipo de ferramenta é o ITS (Intelligent Transport Systems) que vem para ajudar a diminuir as externalidades do transporte utilizando a estrutura física disponível. O ITS possibilita que a infraestrutura seja mais eficiente, inteligente, instrumentalizada e interligada, proporciona a capacidade de prever a demanda e melhor comportá-la à estrutura atual. O uso mais racional do espaço urbano, com auxílio do ITS, proporciona redução de congestionamentos, que, por sua vez, reduz as emissões de poluentes, o consumo de energia e melhora a segurança (ANTP, 2012).

A mudança de paradigma já vem acontecendo de forma singela pelo país, mas podemos citar a cidade de São Paulo como um bom exemplo: no último ano vem executando vários projetos de incentivo ao TPU e aos modos não motorizados. Foram criados mais de $700 \mathrm{~km}$ de faixas exclusivas para ônibus e a estimativa é chegar a $400 \mathrm{~km}$ de ciclovias até 2016. As mudanças não param por aí, houve a redução de velocidade em algumas vias da cidade para tentar fazer o pedestre ser notado, pois a Companhia de Engenharia de Tráfego (CET) afirma que 50\% dos óbitos em São Paulo são decorrentes de acidentes de trânsito em 2014. Para se entender melhor a relação velocidades e risco de morte segue a Tabela 1 mostrando três tipos de acidentes considerando diferentes velocidades de impacto. 
Tabela 1 - Probabilidade de morte de acordo com a velocidade do impacto. Fonte: (FERRAZ, RAIA JUNIOR, et al., 2012)

\begin{tabular}{cccc}
\hline $\begin{array}{c}\text { Velocidade de } \\
\text { Impacto }(\mathbf{k m} / \mathbf{h})\end{array}$ & $\begin{array}{c}\text { Atropelamento de } \\
\text { pedestre, ciclista ou } \\
\text { motociclista }\end{array}$ & $\begin{array}{c}\text { Ocupante de carro } \\
\text { no caso de impacto } \\
\text { lateral }\end{array}$ & $\begin{array}{c}\text { Ocupante de carro } \\
\text { no caso de impacto } \\
\text { frontal }\end{array}$ \\
\hline $\mathbf{2 0}$ & $0 \%$ & $0 \%$ & $0 \%$ \\
$\mathbf{3 0}$ & $8 \%$ & $0 \%$ & $0 \%$ \\
$\mathbf{4 0}$ & $30 \%$ & $0 \%$ & $0 \%$ \\
$\mathbf{8 0}$ & $93 \%$ & $28 \%$ & $3 \%$ \\
$\mathbf{1 0 0}$ & $100 \%$ & $89 \%$ & $32 \%$ \\
$\mathbf{1 2 0}$ & $100 \%$ & $100 \%$ & $90 \%$ \\
\hline
\end{tabular}

Com a Tabela 1, é possível verificar que o UV tem seu risco de agravo aumentando proporcional às altas velocidades, e em áreas mais urbanizadas é fundamental manter as velocidades baixas para propiciar maior segurança aos UVs. Porém, existem questionamentos a respeito. Em geral, esse tema é bastante complexo e, muitas vezes, o poder público sofre críticas sem fundamento, ficando entre dois lobbies: o da segurança viária e o da mobilidade motorizada.

\subsection{Os modos de transporte, seus produtos e externalidades}

\subsubsection{Consumo de Energia, Emissão de Gases, Custo e Uso do Solo}

Cada modo de transporte atrai o usuário de maneira diferente, seja pela praticidade, conforto, economia, manutenção da saúde, rapidez, além de outros motivos. Apesar das vantagens individuais, o uso demasiado de alguns modos pode gerar efeitos negativos à sociedade, às externalidades. Diante das externalidades, os diferentes modos são classificados como mais ou menos sustentáveis. Algumas das características que podemos analisar são: o consumo de energia, a poluição gerada, o custo e o espaço público ocupado pelo transporte. Abaixo vemos uma comparação do Ministério das Cidades em relação às características de cada modo urbano de transporte. 
Tabela 2 - Indicadores Comparativos. (FONTE: Ministério das Cidades, 2007)

\begin{tabular}{ccccc}
\hline \multirow{2}{*}{ MODO } & \multicolumn{4}{c}{ ÍNDICES POR PASS-KM } \\
\cline { 2 - 5 } Ônibus & ENERGIA $^{1}$ & POLUIÇÃO $^{2}$ & CUSTO TOTAL $^{3}$ & ÁREA DE VIA $^{\text {Moto }}$ \\
Muto & 1,0 & 1,0 & 1,0 & 1,0 \\
Bucicleta & 4,5 & 14,0 & 3,9 & 4,2 \\
Bicing & 0,0 & 0,0 & 8,0 & 6,4 \\
\end{tabular}

${ }^{1}$ Base calculada em gramas equivalentes de petróleo (diesel e gasolina)

${ }^{2}$ Monóxido de carbono (CO), Hidrocarbonetos (HC), Óxidos de Nitrogênio (NOx) e Material Particulado (MP).

${ }^{3}$ Custos (totais e variáveis)

Como demonstram os números, os modos motorizados individuais estão com os piores indicadores, ou seja, gastam mais energia, emitem mais poluição e o custo do deslocamento é maior. Por isso, a diminuição do uso destes modos refletiria em maior sustentabilidade nos transportes e, consequentemente, em uma melhor qualidade de vida. A bicicleta se mostrou o melhor indicador em três das variáveis analisadas, em contraponto, a bicicleta está limitada à uma distância menor de viagem do que os outros modos, assim, para um aproveitamento massivo da mesma, a integração com o transporte coletivo é fundamental para a sua disseminação.

Para se ter uma ideia da diferença do impacto ambiental causado por transporte público versus transporte individual, os estudos mostram que o transporte individual é responsável por $75 \%$ da energia consumida em deslocamentos urbanos contra $25 \%$ consumido pelo transporte coletivo. No que diz respeito ao total de deslocamentos, o transporte coletivo é responsável por $60 \%$ deles. Com esses dados, é possível ver a irracionalidade do sistema em que se vive, no qual são consumidos mais recursos do que o necessário, por mera comodidade, e o pensamento coletivo fica esquecido (MINISTÉRIO DAS CIDADES, 2007).

A Tabela 2 mostra alguns indicadores descritivos dos modos, e quanto este pode ser mais entendido por meio da Figura 3. 

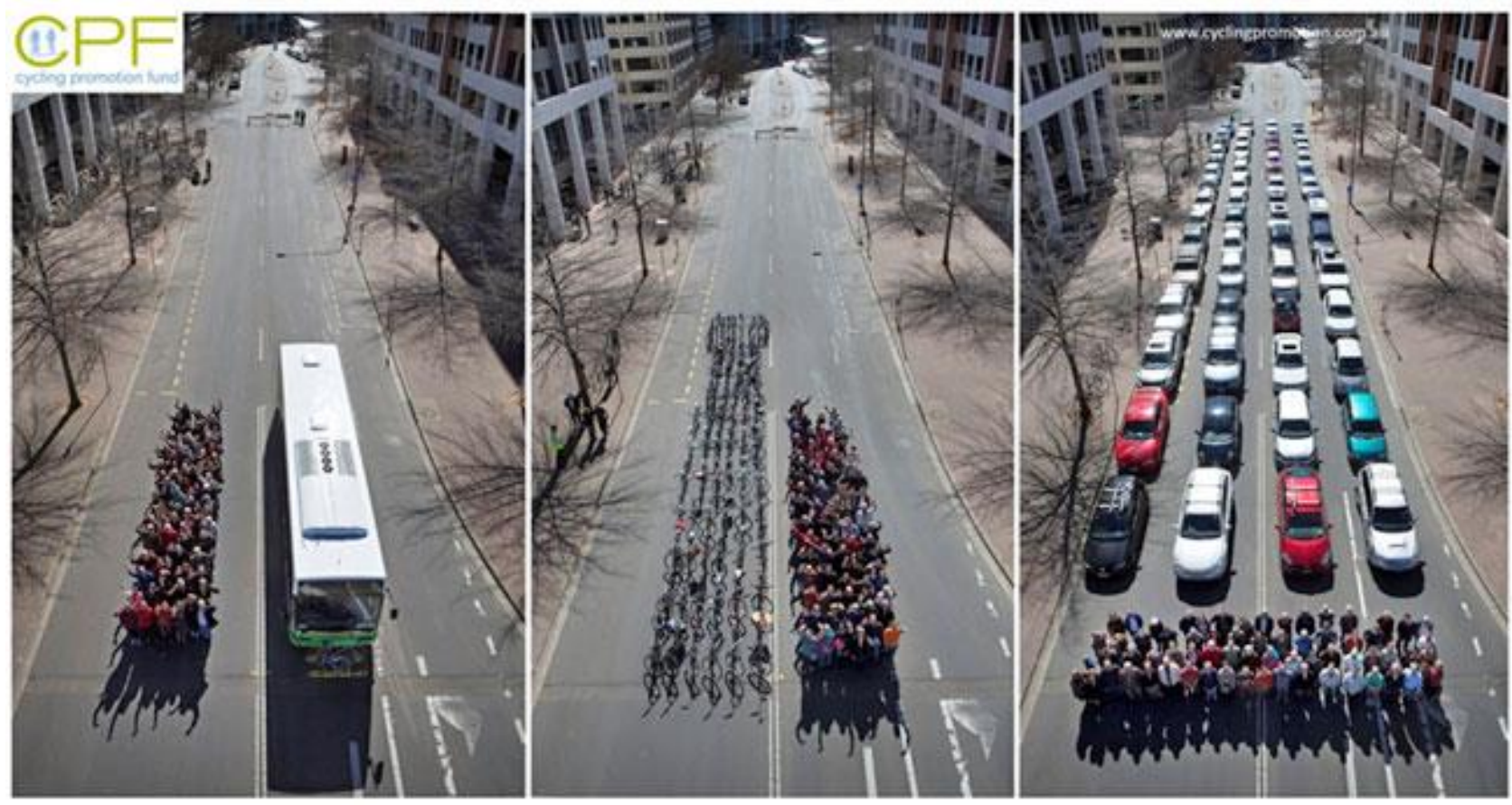

Figura 3 - Uso do Solo por diferentes modos. (FONTE: CPF - cycling promotion fund)

Por meio da Figura 3 é mais fácil perceber que o uso do transporte público e dos modos suaves promove um aproveitamento mais racional do espaço público urbano, e este pode ser disponibilizado ao uso estético, recreacional e social, tornando a cidade mais humana e atrativa.

Todos os indicadores mostrados ajudam a enfatizar a importância da mudança de paradigma, pois o transporte coletivo e os modos não motorizados são os que geram menos externalidades à sociedade. A falta de consciência coletiva gerou a priorização do transporte individual, e ainda não há um pensamento voltado para os benefícios sociais havendo uma distorção na percepção do valor e da qualidade de vida. Hauer (1992) insinua que vale mais a pena morrer do que ficar preso no trânsito, já que o valor agregado do tempo considerado nos estudos de transportes é bem superior ao valor da vida. Isto porque, dentro da tradição do modelo do automóvel, existem dois lobbies antagônicos: segurança e mobilidade. Na verdade, este tema é bastante polêmico e tem grande peso na escolha do modo de viajar de um usuário, e será tratado em mais detalhe a seguir.

\subsubsection{A interferência da variável tempo na escolha modal}

Na atualidade - pós moderna - a variável tempo possui um peso fundamental diante a escolha 
do modo de deslocamento por parte do usuário. Hoje tudo precisa ser mais eficiente, e a expectativa do homem atual é dispor de equipamentos modernos, eficientes e, principalmente, rápidos. Perder tempo não é aceitável, e tirando as questões filosóficas do aproveitar o tempo, todos querem economizá-lo, seja para chegar antes em casa ou para ter mais tempo de estudar ou trabalhar. Os demais atributos de um modo de transporte só são bastante decisivos após a consideração do tempo, pois tempo é, antes de tudo, conveniência além do seu sentido material. É o chegar e não chegar na hora certa em um emprego, em um encontro, mesmo de lazer, e isto se torna decisivo no dia a dia. Se o tempo se torna indiferente, com ambas as opções em vias congestionadas, os atrativos individualistas se tornam decisivos, tornando prioritária a busca de uma solução baseada em um transporte público primeiramente rápido (MINISTÉRIO DAS CIDADES, 2008).

Em estudos de transportes, é assumido que o tempo de viagem é um período de inutilidade. Assim, as pessoas tentam minimizar o tempo da viagem e o custo dela, dentro das restrições de cada usuário (RICHARDSON, 2003). Em termos trabalhistas, o deslocamento é considerado como tempo de trabalho em caso de agravo à saúde; acidente de percurso é acidente de trabalho. Hoje, algumas linhas de pesquisa apontam para o uso do tempo em deslocamento para outras atividades, porém no cotidiano do cidadão urbano com intervalo de trabalho fixo, a redução do tempo de viagem e a confiabilidade do sistema são fatores fundamentais para que o modo seja utilizado. De qualquer forma, o custo do tempo perdido na viagem é calculado com base na renda média do usuário.

Hoje, a redução do tempo gasto com transporte é considerada aumento na eficiência do processo, seja no deslocamento de pessoas ou cargas. O gasto de tempo representa custo, o custo do tempo de viagem é composto pelo tempo se deslocando, mas também pelo tempo de espera, seja em terminais ou em congestionamentos (VTPI, 2013). O tempo perdido dentro de hospitais em tratamentos dispendiosos ou a eternidade das pensões a familiares de vítimas, bem como a desestruturação familiar devido ao óbito são subvalorados, quando não desconsiderados nos estudos de prioridade.

Na busca pela mobilidade urbana sustentável e, com base nos indicadores de externalidades geradas por cada modo, viu-se que o uso integrado de modos suaves e TPU é a maneira que causa mais benefícios à sociedade pensando no tripé Social, Ambiental e Econômico. Muitas vezes, para os usuários, é inviável o uso desses modos devido ao tempo de viagem. Esse 
elevado tempo de deslocamento contribui muito para a migração do usuário do transporte público para o privado, o que torna o sistema insustentável.

A economia no tempo de viagem é frequentemente a principal justificativa para melhorias na infraestrutura dos transportes. Baseados no modelo de planejamento voltado ao automóvel, observa-se um gasto elevado na ampliação do sistema viário, construindo obras de arte e aparelhos de trânsito que possibilitem a diminuição do tempo de viagem. Para o TPU não é diferente, o tempo de viagem caracteriza um fator determinante para a escolha do modo que o usuário irá usar (FERRAZ e TORRES, 2004; VTPI, 2013)

O cuidado com o tempo de viagem do TPU é mais importante do que modos privados, pois o intuito é incentivá-lo, promovendo os benefícios que ele proporciona, tais como, segurança, economia, menos poluição e consumo de energia. A imprevisibilidade do tempo de viagem é visto pelo usuário como um custo adicional e bastante significativo. Devido a essa incerteza, o usuário antecipa a viagem como margem de segurança. No caso de ônibus, a incerteza é muito maior, caso não tenham um sistema de informação ao usuário em tempo real. Para maior atratividade do TPU, é necessária a utilização de equipamentos que proporcionem uma maior previsibilidade ao sistema. O ITS utiliza a tecnologia para gerar benefícios, integrando sinais de localização por satélite com softwares de previsão de chegada dos veículos em pontos de embarque/desembarque (ANTP, 2012).

Deve ser ressaltada a importância de garantir que o ônibus seja priorizado em relação aos automóveis, ou, em termos práticos, não compita com eles em um sistema viário convencional. A adoção de corredores exclusivos (segregação espacial) ou o controle de via através de ITS (segregação temporal) deve ser adotado para garantir tempo de viagem e previsibilidade.

A vulnerabilidade da rede de transportes pode ser percebida por meio de incidentes, tais como pequenos acidentes ou tempestades, que resultam no aumento do tempo de viagem e congestionamentos pesados. A previsibilidade tem alto valor na viagem dos usuários. Estudos apontam que a previsibilidade é mais importante do que resolver congestionamentos, quando de baixa intensidade. Essa imprevisibilidade e o aumento do tempo de viagem são o que faz com que o usuário opte por outros modos e não o TPU (CHEN, SKABARDONIS e VARAIYA, 2003). 
Em Manuel e Hernandéz (2014) são analisadas quatro alternativas de transporte (ônibus, automóvel a etanol, automóvel agasolina e motocicleta). Os modos foram comparados por meio do seu custo de deslocamento, tempo de viagem e emissão de poluentes, representados pelo $\mathrm{CO}_{2}$. Em geral, a emissão de $\mathrm{CO} 2$ não influencia muito na decisão da escolha modal, e sim, o custo e o tempo de deslocamento são determinantes para a escolha. A Tabela 3 permite comparar os indicadores de cada modo.

Tabela 3 - Comparação de indicadores para diferentes modos de transporte. (Fonte: MANUEL e HERNANDÉZ, 2014)

\begin{tabular}{l|c|c|c}
\hline Modo & Custo $(\mathbf{R} \$)$ & Tempo $(\mathbf{m i n})$ & Emissão CO2 $(\mathbf{k g} / \mathbf{l})$ \\
\hline Carro Gasolina & 11,78 & 29,0 & 1,9963 \\
\hline Carro Etanol & 10,56 & 29,0 & 1,1780 \\
\hline Motocicleta & 4,90 & 20,3 & 2,2690 \\
\hline Ônibus & 5,95 & 88,4 & 2,5668 \\
\hline
\end{tabular}

Manuel e Hernandéz (2014) aplicam um método de pesos para cada variável, definidos por meio de pesquisa com usuários. Segundo a pesquisa, o tempo foi considerado o fator mais importante na escolha do modo de deslocamento. A motocicleta foi o modo que apresentou maior prioridade no processo de escolha modal, isso porque é o modo que possui o menor custo e tempo de viagem. Esse estudo mostra a importância do tempo no deslocamento diário das pessoas (MANUEL e HERNÁNDEZ, 2014)

Outros fatores que mostram a importância do tempo de deslocamento são encontrados em novas tecnologias. A popularização do GPS, aliada à disponibilidade de ferramentas de Geoprocessamento de forma livre e gratuita, permite ao cidadão uma maior participação na produção da informação geográfica, assim como o compartilhamento das informações georeferenciadas e sua disponibilização na internet. Esse processo de geração de dados, por pessoas não qualificadas (usuários comuns), é conhecido como Volunteered Geographic Information (VGI), assim denominado por Goodchild (2007).

Ganhar tempo é tão importante que aplicativos de smartphones, como Waze, se popularizam rapidamente. Este aplicativo de distribuição gratuita oferece as funcionalidades de um roteirizador, disponibilizando informações sobre rotas e incidentes, atualizados pelos próprios 
usuários do sistema em tempo real. Isso permite a outros usuários, que estão usando o aplicativo, conhecer e, se for o caso, tomar rotas alternativas e mais rápidas que evitem o provável congestionamento. Assim como os benefícios alcançados com os smatphones, alguns problemas preocupantes surgiram com eles. Essa necessidade por não perder tempo faz com que muitos condutores realizem ligações e até mandem mensagens de texto durante o deslocamento. Essas atitudes tiram o foco do condutor do trânsito, fazendo com que o mesmo divida a atenção entre as duas tarefas, em alguns casos, totalmente incompatíveis, como digitar/visualizar o texto digitado e perceber o trânsito simultaneamente.

Diversos fatores influenciam para o tempo de viagem do TPU, ainda mais quando falamos do transporte por ônibus. Esses fatores podem ser de infraestrutura, como tipo do pavimento, distância entre paradas, existência ou não de faixas exclusivas, plataformas para embarque em nível e itinerários mais retilíneos; na operação o mais indicado são veículos low entry com portas largas para agilizar o embarque/desembarque e a cobrança deve ser realizada fora do veículo (FERRAZ e TORRES, 2004; ITDP, 2008). Alguns parâmetros para que o transporte coletivo seja mais atrativo foram sugeridos por Ferraz e Torres (2004) e estão dispostos a seguir:

Tabela 4 - Parâmetros de atratividade do TPU. (FONTE: FERRAS E TORRES, 2004).

\begin{tabular}{lllll}
\hline Fator & Parâmetro para avaliação & Bom & Regular & Ruim \\
Tempo de & Relação entre o tempo de viagem & $<1,5$ & 1,5 a 2,5 & $>2,5$ \\
Viagem & por ônibus e por carro & & & \\
\hline
\end{tabular}

Pela Tabela 4, é possível verificar que o tempo satisfatório nos deslocamentos de ônibus não pode exceder em $50 \%$ o tempo no deslocamento de automóvel. Vale lembrar que a frequência no atendimento e a confiabilidade do sistema têm que andar juntas para que o tempo de viagem seja satisfatório ao usuário.

A política de incentivo ao uso de transportes individuais, por meio de financiamentos facilitados e pela infraestrutura que os governos disponibilizam, vem criando nas pessoas um sonho por possuir um automóvel. Diante da péssima qualidade do TPU e do tempo de deslocamento ser percebido diferente dependendo o tipo de viagem, as pessoas preferem ficar 10 minutos paradas no congestionamento dentro de seus veículos do que dentro de um ônibus lotado. O congestionamento é o principal motivo de reclamação no trânsito e ele caracteriza a 
perda de tempo parado; o combustível vai e o carro e suas emissões ficam. Hoje, para ganhar tempo, vemos muitas pessoas migrando para a motocicleta que consegue furar $o$ congestionamento e acaba gerando outros problemas que serão abordados mais adiante nesse trabalho (VIEIRA, BASTOS, et al., 2007; VTPI, 2013)

Além disso, o congestionamento é decorrência da falta de infraestrutura devido à demanda de viagens. Porém, essa demanda é decorrência do investimento em vias, o qual favorece o transporte individual que ocupa muito mais espaço por passageiro.km do que outros modos. $\mathrm{O}$ congestionamento é uma externalidade que causa diversos transtornos, inclusive financeiros. O custo dos congestionamentos é estimado entre 1 e $3 \%$ do PIB dos países por ano, isso é decorrência do tempo parado, improdutivo. Além do tempo improdutivo, os congestionamentos aumentam o consumo de energia e intensificam a poluição atmosférica (ANTP, 2012).

O estudo e redução das externalidades até agora abordados é fundamental para que a vida em sociedade melhore. Mas a externalidade mais importante a ser abordada é a gerada pelo acidente de trânsito. A acidentalidade é um problema de saúde pública e seus impactos são enormes à sociedade, devido aos anos potenciais perdidos nos acidentes de trânsito por envolverem, geralmente, pessoas em idade produtiva. O CTB e o Ministério das Cidades dão ênfase na vida que é o elo mais fraco e mais importante nessa complexa cadeia.

\subsubsection{Acidentalidade no Trânsito}

Além das externalidades já citadas, a segurança dos usuários também é fator que impacta na escolha do modo de deslocamento, porém, como o acidente é uma ocorrência de baixa probabilidade, o usuário considera outros fatores antes da segurança. A percepção a respeito do nível de segurança não é algo de domínio do ser humano normal; poucas pessoas deixam de ir ao cinema porque ver televisão em casa pode ser muitas vezes mais seguro. Cabe, assim, ao poder público intervir para garantir a segurança do usuário. Historicamente, o aumento do número de automóveis tem sido acompanhado por um aumento do número de conflitos e de agravos entre usuários vulneráveis. Atualmente a má qualidade do transporte público e a busca pela igualdade social estimulam as pessoas a optarem pelo uso da motocicleta, que apresenta algumas vantagens equivalentes às do automóvel com o benefício de não ficar parada em congestionamentos. O custo de aquisição e de combustível ainda oferece uma 
vantagem financeira sobre o uso do transporte coletivo: tem-se mais flexibilidade, independência e menor custo. Esse tipo de migração aumenta o número de agravos e óbitos, a ponto de se tornar problema de saúde pública, e essa tendência vem acontecendo tanto em países desenvolvidos como países em desenvolvimento (VIEIRA, BASTOS, et al., 2007; FERRAZ, RAIA JUNIOR, et al., 2012; GTZ, 2009).

Para se ter uma ideia global do problema, segundo dados da OMS (Organização Mundial de Saúde), morrem cerca de 1,3 milhão de pessoas anualmente em decorrência de acidentes de trânsito, sendo que a maioria das mortes ocorre em países em desenvolvimento. Com o aumento da urbanização e o uso de transporte urbano, estima-se a piora dessa situação nas próximas décadas. Se não forem tomadas medidas contra a acidentalidade, em 2020 esse número pode chegar a 1,9 milhão de óbitos (EMBARQ, 2015; FERRAZ, RAIA JUNIOR, et al., 2012).

A necessidade de políticas públicas de combate à acidentalidade no trânsito é fundamental para mudar o panorama atual. Em 2008, os acidentes de trânsito foram a $10^{\text {a }}$ causa de óbitos no mundo, cerca de $2,1 \%$ do total. Uma previsão para 2030 é que passe a ser a $5^{\mathrm{a}}$, correspondendo assim a 3,6\% dos óbitos. Quando se fala nos dados mundiais, muitas vezes parece algo distante de nós, mas avaliando o cenário nacional vemos que, em 2010, morreram 42.225 pessoas em razão dos acidentes de trânsito (EMBARQ, 2015; FERRAZ, RAIA JUNIOR, et al., 2012). Para se ter uma ideia da situação brasileira, Bastos (2012) compara a mortalidade em vários, países, utilizando um parâmetro adequado de avaliação de segurança no trânsito, no qual considera a exposição ao risco. Segue Figura 4 comparativa, na qual se pode verificar que a acidentalidade no Brasil é de 7 a 12 vezes maior que nos países desenvolvidos analisados. 


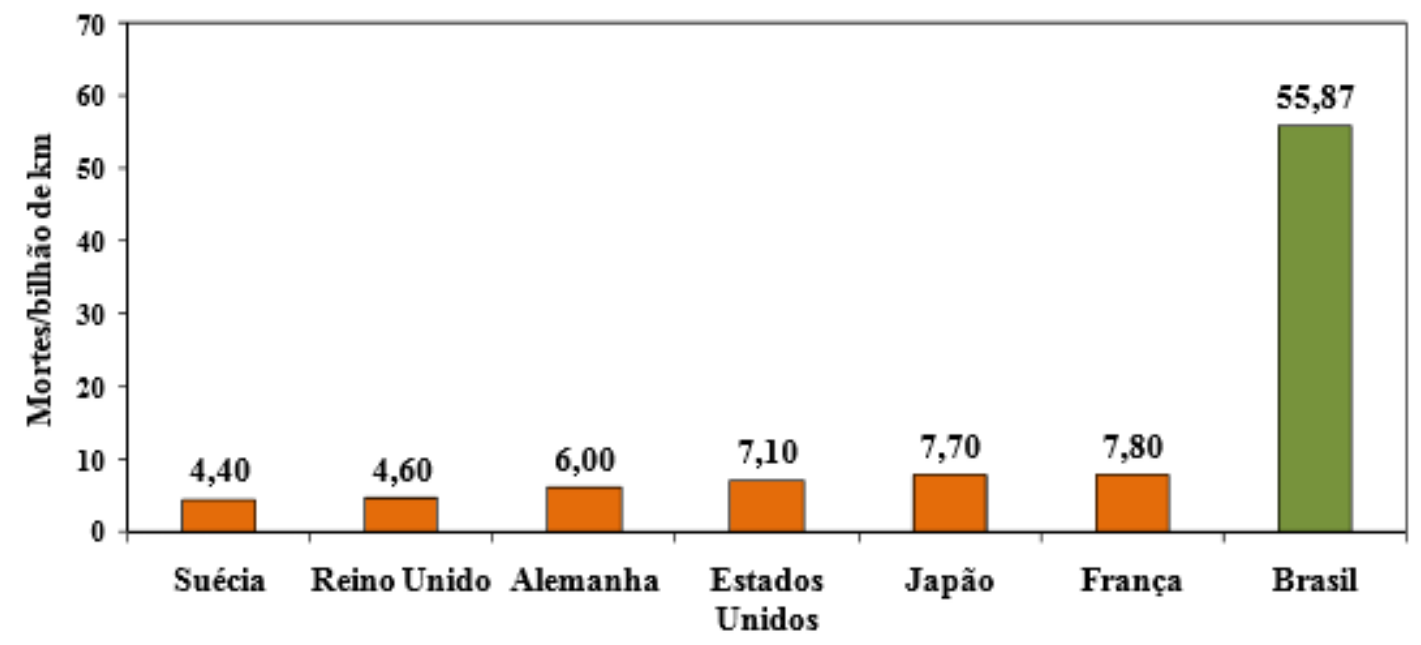

Figura 4 - Comparação do índice de mortes por bilhão de quilômetros percorridos no Brasil (2008) e em outros países (2009). (Fonte: Bastos, 2012)

Apesar da redução gradual do risco, ainda é crítica a situação brasileira atual, ela se repete em diversos países em desenvolvimento, nos quais a motorização aumentou bastante nas últimas décadas, sem a devida preocupação pela segurança. Por isso, a ONU (Organização das Nações Unidas) instituiu a Década de Ações pela Segurança no Trânsito, no período de 2011 a 2020, cuja meta é diminuir o número de mortes em acidentes de trânsito até 2020 em 50\%. Baseado na Resolução da ONU, o Brasil criou o Plano Nacional de Redução de Acidentes e Segurança Viária para a Década 2011 - 2020, o mesmo foi elaborado por um comitê de instituições com expertise no tema, do qual participam diversas organizações ligadas à segurança viária. As diretrizes gerais do plano englobam criação de observatórios regionais para coleta de dados de maneira integrada entre municípios, estados e federação, promoção da segurança principalmente dos Usuários vulneráveis e Usuários do Transporte coletivo, e promoção da acessibilidade universal em todos os programas. Na Figura 5, é demonstrada a importância da Década de Ações pela Segurança no Trânsito, destacando a diferença entre continuar com a situação atual ou agir para que ela mude (EMBARQ, 2015; FERRAZ, RAIA JUNIOR, et al., 2012; ANTP, CEDATT, IE, 2011; MINISTÉRIO DAS CIDADES, 2010). 


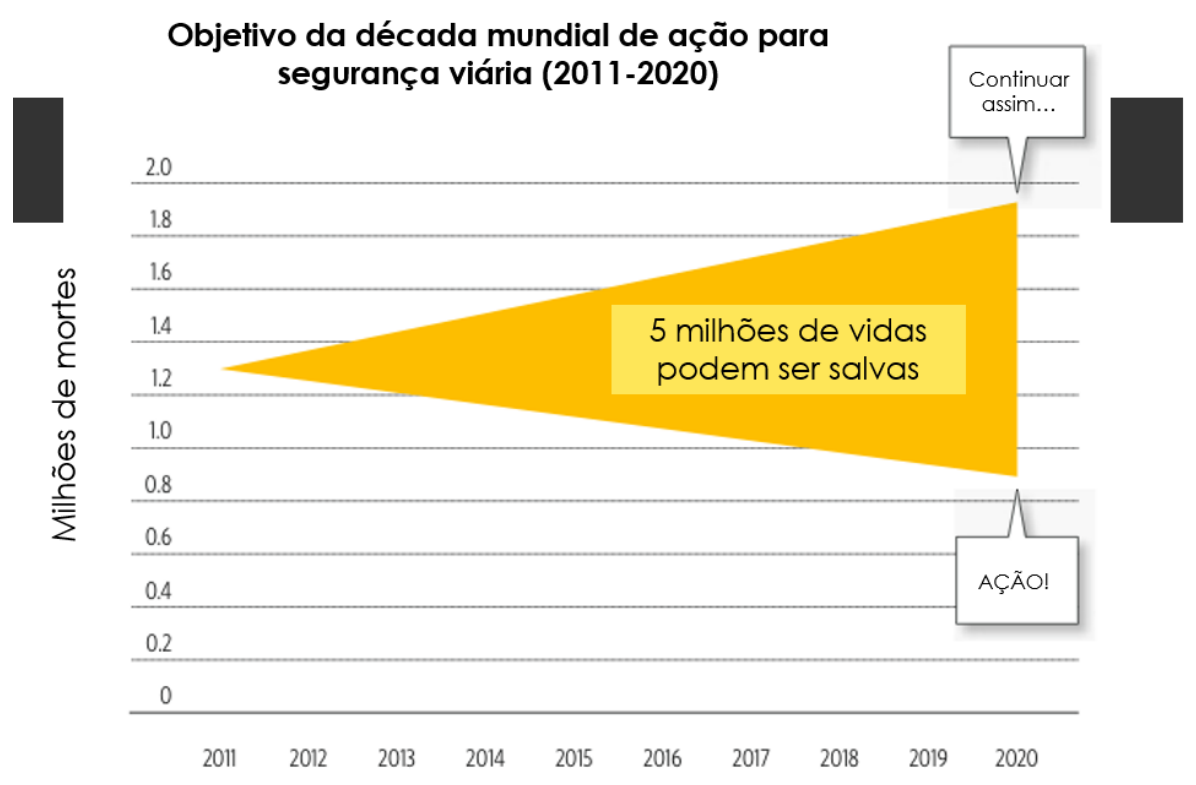

Figura 5 - Objetivo da Década de Ações pela Segurança no Trânsito (Fonte: Observatório Nacional de Segurança Viária)

Vale ressaltar que as diretrizes básicas do Plano Nacional de Redução de Acidentes e Segurança Viária para a Década 2011 - 2020 são, basicamente, o que este trabalho aborda, ou seja, a mudança de paradigma dando ao usuário vulnerável a importância que merece e incentivando o uso do transporte público, mais racional, eficiente e seguro.

A avaliação da segurança e criação de políticas de combate aos acidentes depende da existência de informações confiáveis e da pronta disponibilização desta aos pesquisadores. A importância da coleta e tabulação de análise dos dados de acidentes é inimaginável, pois permite fazer comparações da acidentalidade entre diferentes locais ou no mesmo local, mas em diferentes épocas. Um exemplo da importância dessas cadeias é a comparação do Observatório, mostrada na Figura 6, que demonstra a situação brasileira comparada a outros países.

Para se ter uma ideia da diferença entre a acidentalidade, em países desenvolvidos e em desenvolvimento, é necessário analisar historicamente a evolução da motorização em cada local. A explosão no processo de motorização nos EUA, por exemplo, se deu por volta de 1950 e 1960 (EVANS, 1991) e na década seguinte houve um grande aumento do número de vítimas do trânsito. Esse fenômeno foi combatido de maneira sistêmica, pois o governo investiu em pesquisas e garantiu a sua aplicação prática para combater esse aumento que 
acontecia (VIEIRA, 1999). No Brasil, como em outros países em desenvolvimento, a explosão da motorização foi tardia e a segurança não foi levada muito a sério, o que resultou num crescimento desenfreado da acidentalidade. Algumas ações começaram a ser vistas com o intuito de diminuir a gravidade dos acidentes, como a obrigatoriedade do uso do cinto de segurança e do capacete. Uma medida recente, que deve mostrar resultados nos próximos anos, é a obrigatoriedade dos acessórios de segurança, como freios ABS e Air Bag nos veículos produzidos a partir de 2014. O uso de freios ABS é uma medida ativa, pois atua para evitar que o acidente ocorra. Já o Air Bag é uma medida passiva, que atua após a ocorrência do acidente, para amenizar a sua gravidade.

É vista nos países em desenvolvimento, uma falta de preocupação com a acidentalidade no trânsito. Isso se atribui a problemas mais graves enfrentados além da escassez de recursos, o que se assemelha com a teoria das necessidades humanas de Maslow (FERRAZ, 2012). Apesar de a situação ser crítica e de estarmos lentamente implementando políticas de redução da acidentalidade, o problema nasceu desde a massificação do automóvel (VIEIRA, 1999). O Brasil reduziu os índices de miséria na última década e parece que subimos na pirâmide de Maslow, a qual diz que as necessidades básicas são supridas e a sociedade passa para uma nova fase em que novas prioridades surgem, uma delas é a segurança.

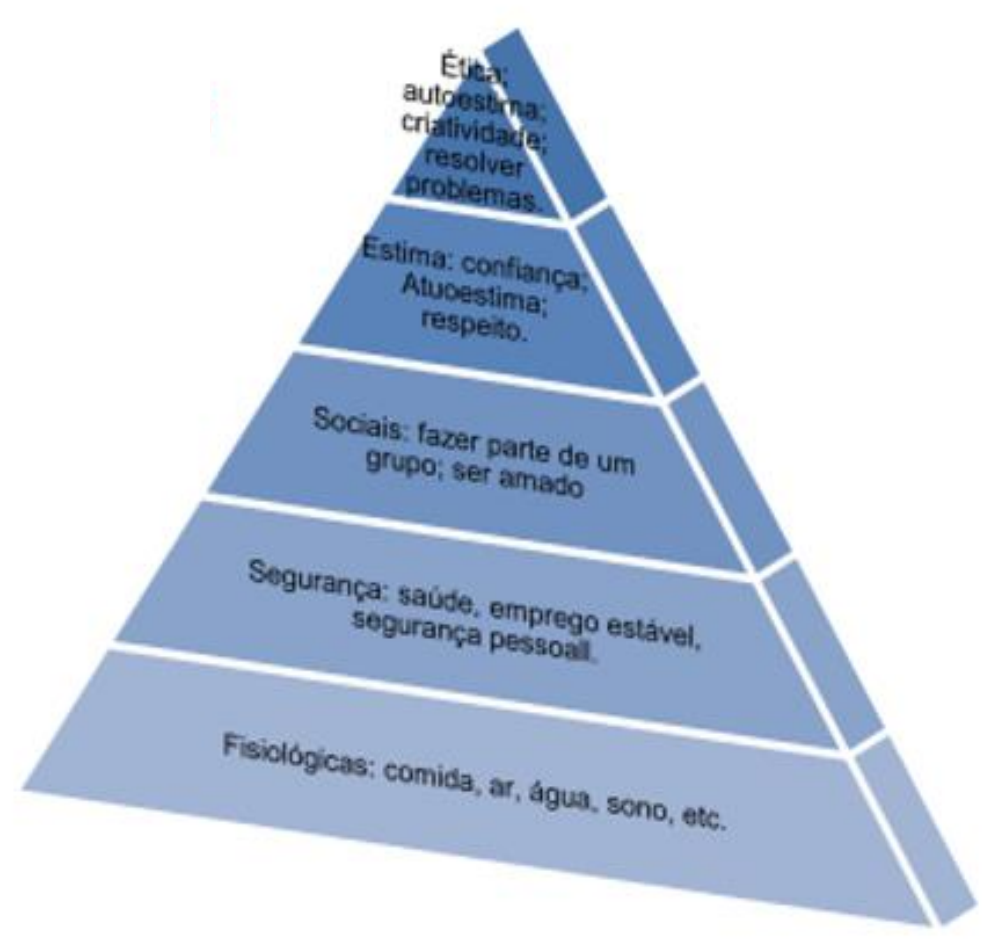

Figura 6 - Pirâmide de Maslow (fonte: Bastos, 2014) 
Mesmo com a evolução de dispositivos de segurança no País, um sistema de transportes sustentável não pode admitir que o elo mais importante da cadeia seja esquecido. O CTB, desde que entrou em vigor, já prioriza a segurança do pedestre, dizendo que os maiores devem cuidar dos menores e os motorizados dos não motorizados. Essa preocupação ganha ênfase nas diretrizes para os planos de mobilidade urbana, solicitados pelo Ministério das Cidades. Isso é a materialização da mudança de paradigma nos transportes urbanos. Esta mudança está inserida na busca por uma mobilidade urbana mais sustentável, já tratada neste trabalho, visando uma melhor qualidade de vida para a população e para as gerações futuras. Para se tratar algo, o primeiro passo é conhecer o problema, por isso as diretrizes do plano de ação contra a acidentalidade propõem a criação de observatórios regionais para a coleta de dados, e, assim, proporcionar a tabulação dos mesmos e auxiliar na tomada de decisões e criação de políticas de redução de acidentes (MINISTÉRIO DAS CIDADES, 2010; CTB,1997).

Hoje, estão disponíveis alguns bancos de dados nacionais, os quais serão tratados mais adiante. Mesmo com os dados oficiais, uma busca em profundidade junto aos Postos Médicos Legais (PML), baseada nos laudos de necropsias, é capaz de identificar relações entre prováveis fatores desencadeadores dos acidentes que não são possíveis de identificar com o dado já tabulado. Os laudos contêm diversas informações sobre o instante da ocorrência, como se deu o fato e o tipo do evento, o que enriquece a análise e pode eliminar efeitos confounder. Assim, considera-se que um tipo de abordagem multidisciplinar permite um melhor entendimento da provável causa ao efeito do processo desencadeado por um acidente de trânsito (FERREIRA, OLIVEIRA, et al., 2011).

A coleta e a tabulação dos dados são fundamentais para que se possa criar contramedidas eficazes no combate da acidentalidade. Para uma análise mais detalhada, os dados necessitam ser desagregados e com o máximo de informação possível, pois assim o efeito confounding pode ser controlado de uma forma mais abrangente, uma vez que as decisões devem ser tomadas, e seus resultados devem ser avaliados no menor espaço de tempo possível. Além disto, a disposição da massa de dados sob uma forma mais desagregada permite que se criem mais possibilidades de controle, oportunizando maior robustez aos estudos comparativos espaciais - entre dois locais - ou temporais - antes e depois (VIEIRA, 1999; BASTOS, 2008). 
A importância de se utilizarem referências de controle pode ser demonstrada através de um exemplo simples: a implementação de uma medida de segurança ativa em relação às colisões traseiras (CT), por exemplo, como a colocação de placas de advertência sobre os riscos do desrespeito à distância de segurança e fiscalização ostensiva. Supondo que a contramedida foi adequada, isto deverá se refletir na proporção destas colisões em relação aos demais acidentes. Por outro lado, o mesmo não deverá acontecer em outros segmentos não tratados, pelo menos não da mesma forma e intensidade. A utilização de segmentos de rodovia, que não foram tratados e mesmo de outros tratados, pode fornecer evidências da relação entre a medida e a intervenção, mesmo sob a presença de confounders (VIEIRA, 1999).

Além do aspecto da relação de causa e efeito, esta tipologia deve ser utilizada, principalmente pela sua capacidade de diferenciar os acidentes também em relação aos seus custos. Os diferentes tipos de acidentes geram números médios diferentes de acidentes, mortos, feridos, veículos envolvidos e, portanto, acarretam custos também diferenciados. Isso melhora muito as condições da avaliação, pois as variáveis (tipos de acidentes) são mais relacionáveis às medidas avaliadas. Com isto, os seus benefícios podem ser mais precisamente determinados (VIEIRA, 1999).

Como o acidente é um evento raro e imprevisível, a frequência do acidente varia de acordo com o local. Analisando períodos muito pequenos, não é possível verificar a tendência da curva devido a essa variação. Quando um período de alta frequência é observado, é provável que seja seguido por um período de baixa frequência, assim essa variação é difícil de explicar. O HSM (2010) sugere análises a curto prazo, ano a ano, e a longo prazo analisando períodos maiores para tentar entender a tendência da curva de acidentes.

A obtenção dos dados e identificação da causa dos acidentes é decorrência de um conjunto de fatores que levam ao seu acontecimento. Esses fatores de influência têm basicamente três origens, humano, engenharia ou ambiente. Um estudo apresentado no HSM (2010) mostra que, na maior parte das vezes, o fator humano está presente nos eventos que geram acidentes de trânsito (ver Figura 7). 


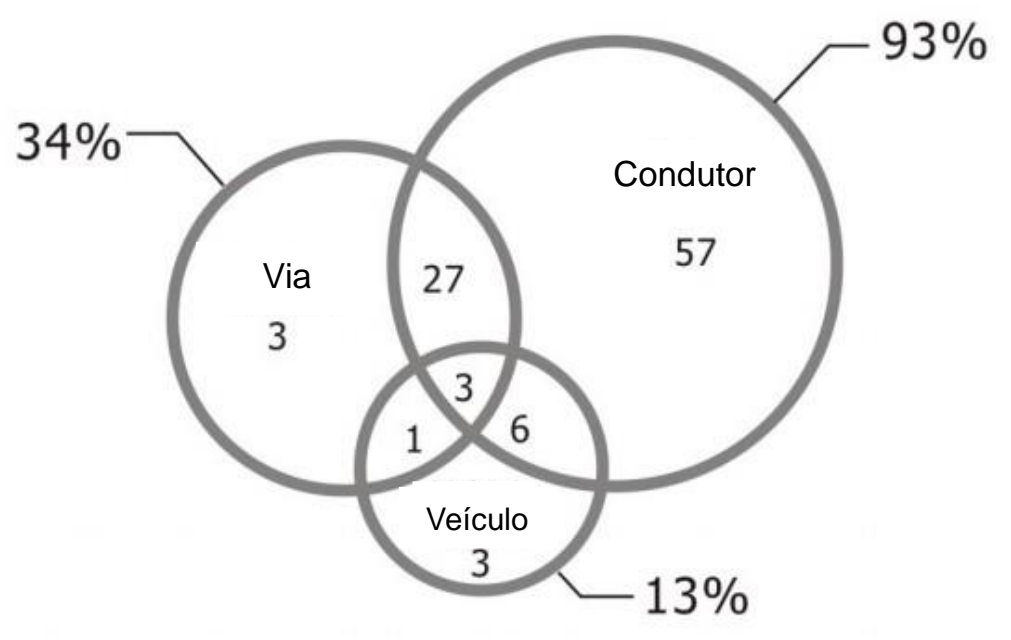

Figura 7 - Fatores que influenciam no acidente. (Fonte: HSM, 2010)

Sendo o fator humano o que mais colabora com a ocorrência do acidente, tirar a pessoa da condução e colocá-la no transporte coletivo sem dúvida melhoraria os indicadores de acidentalidade. Isso porque o transporte coletivo apresenta menores riscos, além de ser um veículo mais robusto e mais visível, é conduzido por um motorista profissional.

A análise do acidente é complexa e, como já foi falado, envolve diversos fatores e áreas de atuação, mas, geralmente, os problemas de tráfego são apresentados como problemas em uma dimensão, ou seja, distribuição de acidentes, feridos ou mortos ao longo do tempo ou por tipo de veículo ou faixa etária, por exemplo. Sendo a segurança no trânsito um problema que envolve diversos fatores e áreas de atuação, uma análise tridimensional pode ajudar a visualizar o problema de uma maneira mais ampla.

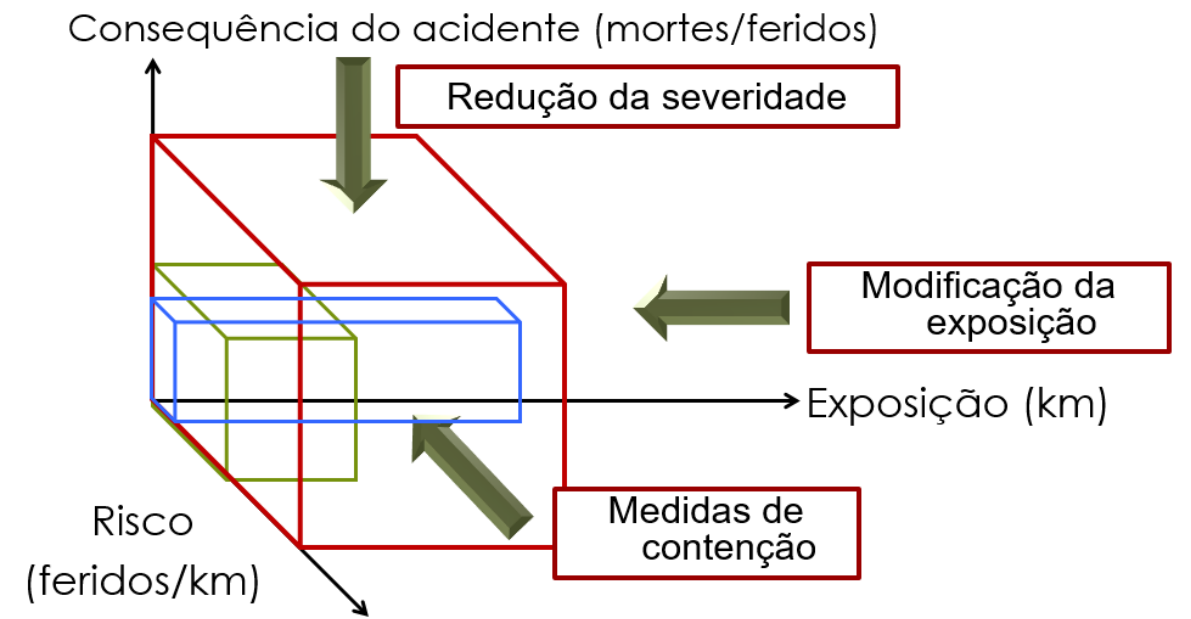

Figura 8 - Análise Tridimensional do Acidente (fonte: Nilsson, 2004) 
A Figura 8 mostra um modelo tridimensional de acidentes, o qual avalia o Risco, a Exposição e as Consequências dos Acidentes segundo três eixos de mensuração, que orientam a melhor forma de intervir na acidentalidade. Seguem algumas ações que podem ser realizadas para a diminuição de cada eixo:

- Redução da Severidade: melhorar o atendimento pós acidente, melhoria nos equipamentos de segurança.

- Modificação da exposição: colocar a pessoa em modos mais seguros

- Medidas de Contenção: modificações físicas na via e campanhas educativas.

Este trabalho trata da diminuição da exposição, tentando levar o usuário de um modo menos seguro para um mais seguro, por considerar que nesta forma de pensar melhora-se o padrão de segurança e, simultaneamente, colabora-se para a redução do congestionamento e da poluição ambiental. Hoje se sabe que os modos individuais são os responsáveis pela maior parte dos óbitos, devido a sua desproporcionalidade de massa quando ocorre um acidente com modos suaves ou com motocicleta. A Tabela 5 mostra a distribuição de vítimas por modo na cidade de Caxias do Sul, no ano de 2012.

Tabela 5 - Vítimas de acidentes de trânsito por modo, Caxias do Sul RS, 2012 (Fonte: DATASUS)

\begin{tabular}{|l|c|c|}
\hline Tipo de Acidente & Óbitos & Proporção \\
\hline Pedestres traumatizados em acidentes de Trânsito & 20 & $30 \%$ \\
\hline Ciclistas traumatizados em acidentes de Trânsito & 1 & $1 \%$ \\
\hline Motociclistas traumatizados em acidentes de Trânsito & 26 & $39 \%$ \\
\hline Ocupantes de Automóveis traumatizados em acidentes de Trânsito & 18 & $27 \%$ \\
\hline Ocupantes de Ônibus traumatizados em acidentes de Trânsito & 2 & $3 \%$ \\
\hline Ocup. de Veículos Pesados traumatizados em acidentes de Trânsito & 0 & $0 \%$ \\
\hline \multicolumn{1}{|c|}{ TOTAL } & 67 & $100 \%$ \\
\hline
\end{tabular}

Ao analisar a Tabela 5, percebe-se que o maior número de óbitos se concentra no grupo dos UVs, ou seja, $70 \%$ do total de óbitos ocorrem entre pedestres, ciclistas e motociclistas. Se os dados estivessem disponíveis de maneira mais desagregada seria possível avaliar qual o maior responsável pela morte de pedestres, mas, obviamente, pelos números, são a motocicleta e o automóvel.

Entre as quatro externalidades analisadas pelo Ministério das Cidades, na maioria das vezes, apenas o custo da viagem é considerado pelos usuários, no momento de escolher o tipo de transporte. A segurança, como já citado, tem pequeno impacto na escolha modal, porém, como a probabilidade de ocorrência do acidente é baixa, o usuário não leva tão a sério um 
modo ser mais ou menos seguro que o outro. Já o tempo é o fator mais importante nessa escolha, mas é importante saber que as escolhas modais dos usuários podem gerar outras externalidades e, consequentemente, influenciar na escolha futura.

O incentivo para utilizar modos de transporte mais seguros depende do governo e, historicamente, percebe-se que, quanto mais cresce o uso de automóveis e motocicletas, mais aumenta o número de agravos, seguidos ou não de mortes e sequelas. Isso acontece porque os modos motorizados possuem massa e velocidade muito superiores aos do pedestre que, em caso de acidente, sempre é o mais prejudicado. A mídia também não colabora com o uso de modos não motorizados, primeiro porque seus patrocinadores são empresas que lucram muito com a venda dos veículos e, complementando, ainda mostram a triste realidade dos pedestres e ciclistas que precisam utilizar rotas conflitantes com automóveis e acabam sendo massacrados, enquanto o ocupante do automóvel apresenta-se como vítima com menor frequência, indicando uma provável maior segurança para seu usuário (GTZ, 2009; GEHL, 2012).

\subsubsection{Bancos de dados de acidentes de trânsito}

O registro dos acidentes de trânsito, com o máximo de informação possível, é fundamental para a constituição de banco de dados, permitindo o processamento de forma sistêmica para uma análise dessa informação posteriormente. Um banco de dados atualizado e confiável é essencial para que as ferramentas de auxílio no processo de tomada de decisão sejam efetivas e possibilitem uma rápida análise. Para um país, dados confiáveis são importantes para fundamentar os líderes políticos de que os malefícios causados por acidentes de trânsito são uma questão prioritária. Esses dados também podem ser usados para informar a população, por meio da comunicação e divulgação dos mesmos, conscientizando-a sobre a legislação e mudanças de comportamento que podem melhorar sua segurança (FERRAZ, RAIA JUNIOR, et al., 2012; ROMÃO e DE CAMPOS, 2011).

Hoje, existem três bancos de dados de âmbito nacional, sendo eles o Renaest (Denatran), Datasus (Ministério da Saúde) e o DPVAT. Romão e De Campos et al. (2011) apontam algumas características de cada um destes bancos de dados. O estudo conclui que o DPVAT apresenta os maiores números absolutos de óbitos no trânsito, mas o registro é feito com base 
no ano do recebimento da indenização. Já o Datasus se mostra mais confiável na forma de coletar e tratar os dados, pois a fonte é um documento obrigatório à certidão de óbito. No caso do RENAEST, ele é o banco de dados mais utilizado pelos órgãos públicos, porém apresenta os menores números, devido à questão da subnotificação.

Oliveira (2012) compara os laudos do Posto Médico Local (PML) com o banco de dados Datasus e conclui que, no caso do município do Rio Grande - RS, as proporções entre os acidentes e outros dados de natureza macro, não mostram diferenças significativas se comparados aos obtidos em busca direta nos arquivos do PML. O banco DATASUS, no caso local, parece refletir de forma mais ou menos acurada o quadro geral da busca profunda. Nesta última, podem ser obtidas informações sobre o momento da ocorrência, o local e a forma de participação dos veículos e dos seus ocupantes, essenciais para a determinação do risco relativo.

Oliveira (2012) também ressalta a importância da pesquisa com dados desagregados, obtidos nos boletins de ocorrências, anexados apenas aos laudos de necropsia, os quais permitem a complementação da coleta de dados por meio da interpretação das circunstâncias da ocorrência, informando veículos envolvidos, local da ocorrência do acidente, gênero e idade das vítimas e dos autores. Então, estes boletins possibilitam coletar mais informação, de modo desagregado, para a realização das análises.

\subsection{Indicadores de Mobilidade Sustentável}

Como já citado anteriormente, a aglomeração desordenada de pessoas, nos centros urbanos, gera diversos problemas em diferentes áreas do conhecimento. No entanto, é necessário estabelecer um indicador para que se possa, de alguma forma, estabelecer um patamar de avaliação, ou seja, o quão ajustado está o cenário ao homem, e poder usar isto como uma baliza para acompanhar e avaliar as ações de desenvolvimento urbano e mobilidade.

Em países desenvolvidos, o uso de indicadores está bastante disseminado, sendo estes bastante utilizados tanto na área acadêmica como na política e administrativa. No Brasil, vemos o crescimento dos estudos acadêmicos, no sentido de analisar a nossa situação atual, padronizando indicadores e podendo realizar diversas análises, bem como prever cenários 
futuros (BASTOS, 2011).

A mobilidade urbana sustentável ideal é um tanto quanto utópica, quando pensada considerando as limitações atuais da tecnologia, entretanto, o estágio atual parece, em alguns aspectos, utópico em relação a um passado não muito remoto. No escopo deste trabalho, busca-se um indicador que represente a má adaptação do meio urbano aos modos suaves de deslocamento e que, simultaneamente, seja capaz de incluir uma externalidade do mau serviço prestado pelo transporte público e pelo automóvel, impacto do crescente uso de motocicletas. Entre os usuários vulneráveis são incluídos pedestres, ciclistas e motociclistas, constituindo um mix que torna difícil padronizar uma base de risco, em distância viajada, por exemplo.

Os determinantes da ocorrência de acidentes entre pedestres ou ciclistas, com veículos motorizados, são o número e o tipo de conflitos que requerem uma análise complexa. Considerando este aspecto, a utilização de uma razão vulneráveis/não vulneráveis apresenta variáveis de um mesmo período e sujeitas aos mesmos impactos econômicos e climáticos.

\subsubsection{Modos Motorizados}

\section{- Transporte Público Urbano (TPU)}

O TPU teve origem na palavra Omnibus, em latim. Essa frase mostra a importância do transporte coletivo bem como a sua responsabilidade. O TPU é responsável por atender uma das necessidades básicas da população, prevista na constituição, porém, apenas o fato de existir não significa que esteja desempenhando seu papel de forma satisfatória. É preciso atender algumas características para que o transporte seja atrativo aos usuários, o que nem sempre acontece. Muitas vezes, o TPU de péssima qualidade faz com que os usuários optem por outros modos de deslocamento para melhorar sua mobilidade (FERRAZ e TORRES, 2004).

Esta migração entre modos acontecia, na maioria das vezes, para o automóvel, símbolo de status e conforto. Atualmente, uma parcela dessa migração ocorre para a motocicleta, por ser uma alternativa de baixo custo e que proporciona a mobilidade equivalente à do automóvel, porém com um conforto e uma segurança substancialmente menor. Apesar do benefício 
individual obtido com os modos individuais, seu uso intenso provoca congestionamentos, impactando negativamente na qualidade do transporte coletivo, quando este compartilha a infraestrutura com os automóveis. Com uma média de 1,3 passageiros transportados por veículo, o automóvel usa o solo de forma irracional pelo baixo volume de pessoas deslocadas por área de via ocupada. A Figura 9 mostra um comparativo do uso do solo entre os diferentes modos:

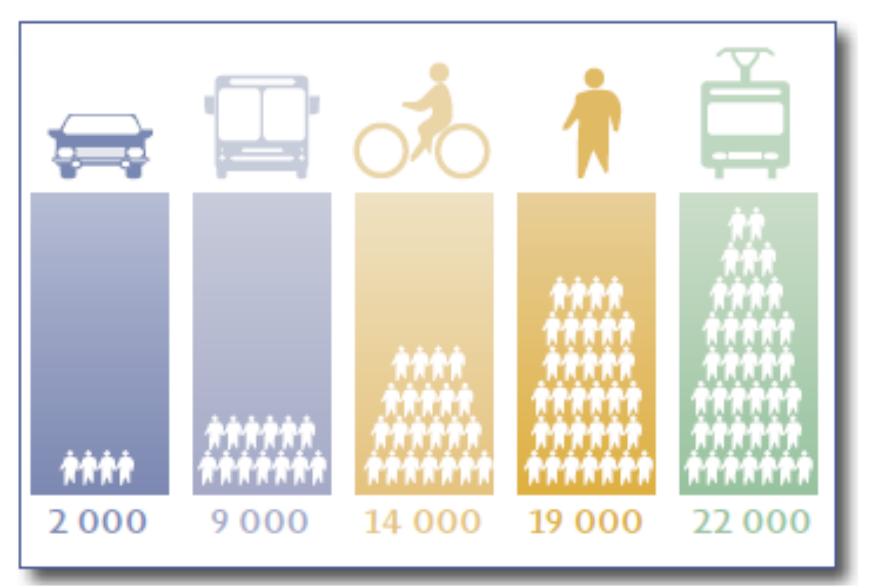

Figura 9- Pessoas por hora em uma faixa de 3,5 m de largura (fonte: GTZ, 2012)

Apesar de o TPU apresentar uma enorme gama de vantagens sociais, econômicas e ambientais, em relação aos transportes individuais motorizados, os benefícios individuais têm peso maior na escolha do modo pelo usuário. Assim, alguns parâmetros devem ser cuidados para que o TPU seja mais atrativo do que os demais modos e consiga manter seus usuários, além de tentar atrair novos. A condição sine qua non para que isso ocorra é o tempo de viagem e a frequência.

No âmbito dos benefícios, o TPU é acessível a pessoas de todas as classes sociais, o que proporciona acesso aos equipamentos públicos sem restrição. O TPU também é sinônimo de uso mais racional do espaço público, pois transporta muito mais pessoas usando menos espaço que o automóvel, por exemplo (Figura 9). Na área ambiental, a emissão de poluentes é muito menor por passageiro transportado (Tabela 2). Além dos benefícios citados, o uso de TPU representa uma proteção ao usuário em relação à chance de sofrer alguma lesão em caso de acidente. Além das exigências para um condutor profissional serem maiores, características do modo, tais como, a massa e o volume veicular elevados, no caso de acidentes, geralmente, não experimentam grandes desacelerações e oferecem uma "armadura" considerável. A visualização de um veículo de grande porte é mais fácil, tanto por parte de condutores como por pedestres e, se circularem em canaleta exclusiva, se tornam mais previsíveis em relação à 
sua trajetória e, portanto, oferecem menos riscos. A Tabela 6 mostra a diferença de risco relativo entre os modos de transporte urbano:

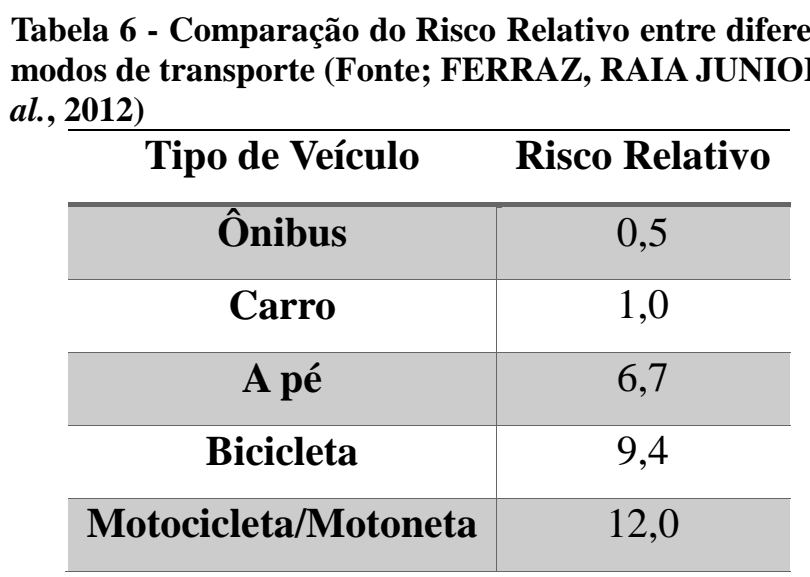

Diante das vantagens apresentadas, o percentual das viagens urbanas realizadas no TPU é, por si só, um indicador de mobilidade urbana sustentável devido a essa gama de benefícios, e o seu percentual de uso na matriz de transportes urbana pode ser usado para analisar as condições do Usuário Vulnerável diante do novo paradigma do transporte e levar os usuários dos modos individuais para o TPU já aumentaria a segurança como um todo (FERRAZ et al., 2004; MINISTÉRIO DAS CIDADES, 2008). O transporte público atrativo estimula o hábito de caminhar, complementando o pedestre ou o ciclista em relação a suas possibilidades de deslocamento, ampliando seu raio de ação por modo suave de deslocamento. Quanto mais pedestres, menos carros e quanto menos carros, menos conflitos com os UVs e menos vítimas entre os mesmos.

Para a valorização do usuário vulnerável, não é apenas necessário uma rede de transportes física para o deslocamento, mas também um planejamento urbano que pense nisso, proporcionando acessos e integração ao transporte público, permitindo ao usuário ampla e total mobilidade (GTZ, 2009). Para que o uso do TPU seja viável e atrativo este deve estar perto do usuário, por isso, a análise da equidade do sistema é fundamental para saber se essa opção atende toda população. As políticas TOD direcionam o investimento para o entorno de linhas e estações do TPU, tratando a microacessibilidade desta área e aproximando o usuário do transporte público, tornando a sua vida mais fácil e produtiva.

A melhoria do entorno, baseado na metodologia TOD, está relacionada com a valorização e segurança do usuário vulnerável, que é o elo mais fraco na cadeia de transportes, 
desenvolvendo o seu habitat. O sistema de desenvolvimento de entorno, bem como a priorização do sistema de ônibus, tem atraído estudos da WRI Ross Center for Sustainable Cities, realizados em Ahmedad, India e Guadalajara, México, que mostram claramente que o transporte público pode melhorar a segurança, reduzindo lesões e mortes em até $50 \%$. Assim, além de toda gama de benefícios do TPU, ele está diretamente relacionado à segurança dos usuários de outros modos de transporte (EMBARQ, 2015).

\section{- Motocicleta}

A falta de planejamento nas áreas urbanas, muitas vezes, gera a fragmentação do uso do solo. Somando isso ao TPU de péssima qualidade, e com custos operacionais altíssimos, pressionam a tarifa para cima, levando as pessoas insatisfeitas a buscar alternativas para se incluírem socialmente. A motocicleta representa essa inclusão social, devido ao seu baixo custo de aquisição e manutenção. Na última década, o crescimento de motocicletas no território nacional disparou, bem como em outros países. O seu uso massivo, apesar de gerar esses benefícios citados, gera prejuízos à sociedade devido ao aumento acentuado dos acidentes com envolvimento de motocicletas (VIEIRA, BASTOS, et al., 2007). A Figura 10 demonstra o crescimento da frota de veículos de duas rodas no Brasil, ao longo de 10 anos em comparação a automóveis, caminhonetes e utilitários.

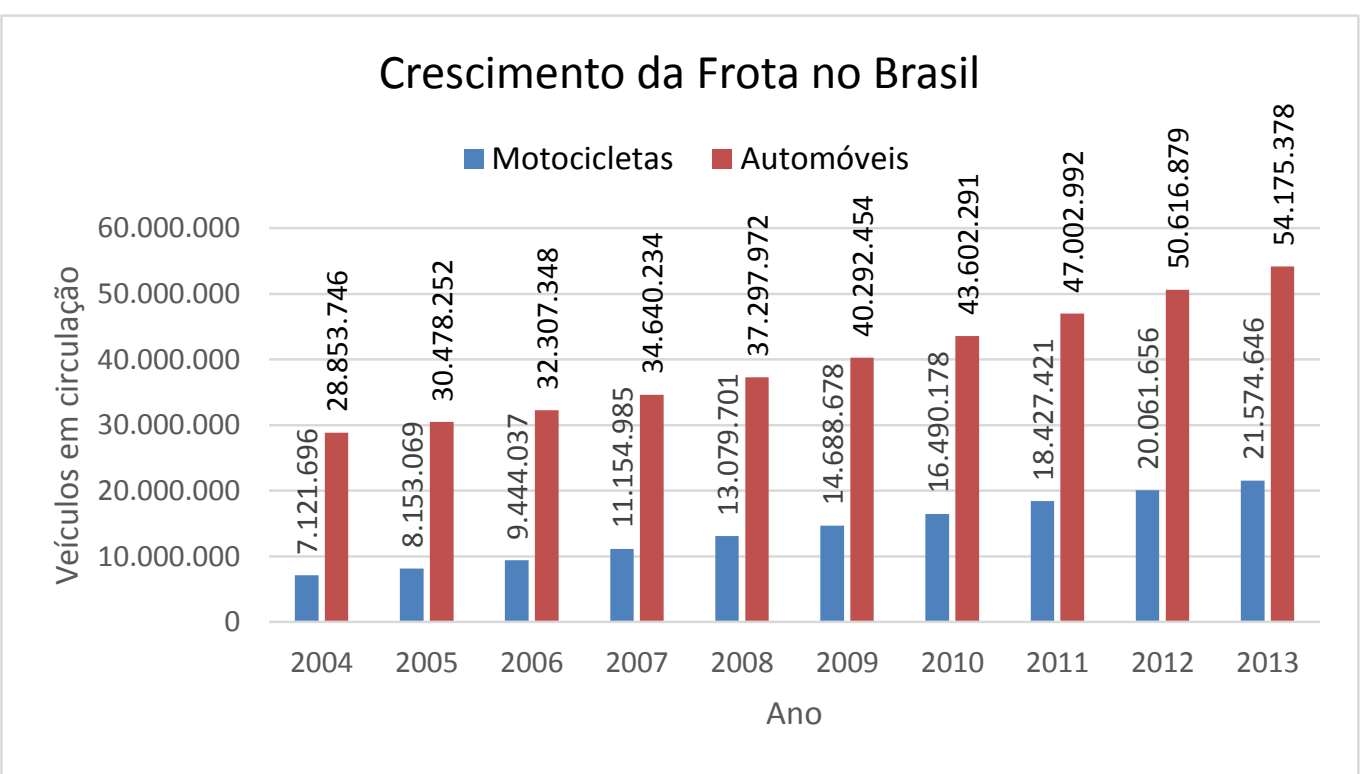

Figura 10 - Evolução da frota de motocicletas e automóveis no Brasil (fonte: DENATRAN) 
Observa-se que em 2013 o número de motocicletas é três vezes maior que em 2004, já o número de automóveis, no mesmo período, dobra de tamanho. Essa comparação mostra a tendência do uso da motocicleta devido a suas vantagens econômicas e de mobilidade. $\mathrm{Na}$ Figura 11 pode-se observar o aumento percentual da frota, no mesmo período do gráfico anterior, na qual vemos que o crescimento da motocicleta é sempre maior que do automóvel.

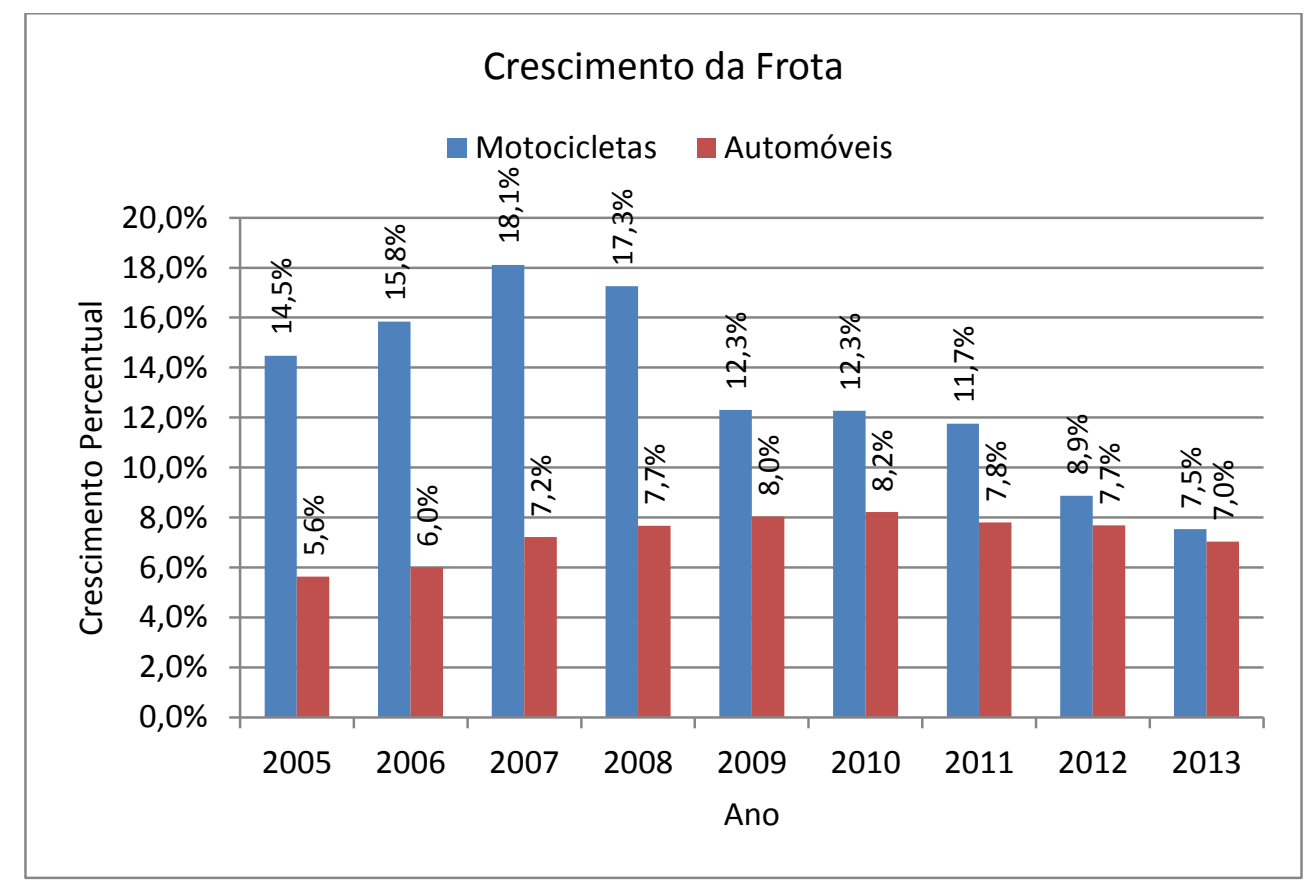

Figura 11 - Crescimento anual da frota em relação ao ano anterior (fonte: DENATRAN)

O aumento no número de motocicletas pode ser usado, na atual conjuntura, para estimar o aumento da exposição ao risco, pois a exposição está relacionada com o uso, e o índice mais apropriado seria avaliar o aumento da quilometragem total percorrida pela frota em questão (BASTOS, 2011). No entanto, ocorreu um aumento da circulação de motocicletas, o que é um fato preocupante, diante do ponto de vista do transporte sustentável, devido ao alto envolvimento deste modo com os acidentes. Isso se dá devido à baixa conspicuidade do conjunto moto/motociclista, bem como pela atitude típica do condutor de motocicletas, que tende a respeitar menos as leis de trânsito. Apesar da adequação do método proposto por Bastos (2011) para calcular o grau de exposição, no Brasil ainda faltam bancos de dados para realizar essa análise em microrregiões. Um dos problemas, ressaltados por Bastos (2011), é que os dados precisam estar mais desagregados por tipo de combustível usado. Assim, usou- 
se o dado do crescimento da frota para representar a tendência do aumento do uso do modo, mas não do aumento proporcional do uso.

\subsubsection{Transportes Suaves}

A busca incessante por soluções imediatistas fez com que o transporte suave fosse, muitas vezes, esquecido pelos gestores públicos. No entanto, a valorização do usuário de transporte suave vem para mudar o paradigma do século XX. A linha de planejamento proposta, atualmente, elimina algumas limitações de distância, oriundas da energia muscular utilizada para mover a bicicleta, por exemplo. Uma rede viável é uma rede integrada com o transporte público, com o sistema de calçadas e que permita servir a todas linhas de desejo possíveis por meio desta integração. Grande parte das viagens do dia a dia, principalmente em cidades de porte médio, envolvem distâncias cicláveis e mesmo caminháveis; a mobilidade suave é uma alternativa sustentável para a maior parte dos problemas nestas cidades, nas quais $60 \%$ dos deslocamentos urbanos são com distâncias de 3 km ou menos (GTZ, 2009).

A boa condição de passeios públicos e a presença de rotas cicláveis propiciam um melhor deslocamento de pessoas com deficiência física, as quais são as mais prejudicadas diante desses equipamentos públicos mal executados, em uma escala inadequada mesmo para pessoas sem qualquer tipo de limitação física. As rotas cicláveis não dão suporte apenas para bicicletas, mas também para patins, skates, cadeiras de rodas entre outros modos suaves (MINISTÉRIO DAS CIDADES, 2007).

\section{Passeio Público}

Todos somos pedestres: essa frase resume a importância dos passeios, pois sempre é necessário o deslocamento a pé. O passeio público representa o desenvolvimento de um local. O pedestre, no entanto, precisa de condições para ter um deslocamento eficaz e seguro. Calçadas com largura e pavimento adequado são o mínimo que o usuário deve dispor para um deslocamento satisfatório. O ex-prefeito Enrique Peñalosa, considerado por muitos como um grande pensador urbano, insinuou, ao ser questionado sobre a qualidade urbana de Porto Alegre - RS, que ruas largas e calçadas estreitas eram típicas de países emergentes. Além da largura adequada, a calçada não pode ter buracos, degraus, nem ser de material irregular. A 
Tabela 7 mostra os parâmetros mínimos para os passeios na Cidade de Caxias do Sul - RS, definidos no plano diretor municipal.

Tabela 7 - Parâmetros mínimos para passeios públicos (fonte: Plano Diretor na cidade de Caxias do Sul)

\begin{tabular}{cccc} 
& Largura mínima & $\begin{array}{c}\text { Inclinação longitudinal } \\
\text { máxima }\end{array}$ & $\begin{array}{c}\text { Inclinação transversal } \\
\text { máxima }\end{array}$ \\
\hline Passeio mínimo & $2 \mathrm{~m}$ & $18,00 \%$ & $3,00 \%$ \\
\hline
\end{tabular}

\section{Rotas Cicláveis}

O uso da bicicleta pode ser uma alternativa suave ao uso de TPU, bem como pode ser usado integrado ao TPU. O uso deste modo acarreta em diversos benefícios sociais e individuais.

\section{Individuais:}

- Melhoria na mobilidade;

- Melhoria na saúde;

- Economia financeira.

\section{Sociais:}

- Menor emissão de poluentes;

- Uso mais racional do espaço público;

- Melhoria da igualdade social;

- Boa combinação c/ TPU;

- Melhoria da segurança das vias;

- Economia local mais forte.

Para que os benefícios sejam alcançados, o sistema deve ser coerente e atrativo aos usuários. Podemos citar os cinco principais parâmetros para uma infraestrutura atrativa para ciclistas:

- Coerência nas rotas (liguem locais usuais pelos usuários);

- Rota direta (o nome já diz, sem muitas delongas);

- Segurança (item abordado no item segurança);

- Atratividade (infraestrutura conveniente ao ciclista);

- Conforto (piso confortável, asfalto ou concreto) 
(GTZ, 2009).

A bicicleta, por ser um modo de baixíssimo custo, é associada à falta de recursos e vista com relutância nos países emergentes, sobretudo quando há uma ascensão econômica do indivíduo, já que esse veículo é normalmente discriminado pelas autoridades que não se dispõem a pagar o custo 50 a 90 vezes mais baixo por um quilômetro de via que, além de promover a qualidade ambiental, proporciona mobilidade e contribui para a integração social e a saúde. Em países altamente desenvolvidos em mobilidade suave, busca-se incluir, neste modo, os chamados colarinhos brancos, investindo em cofres seguros para guarda de suas valiosíssimas bicicletas e disponibilização de vestiários para higienização pós-pedalada. Em relação à segurança, é claro que a bicicleta possui uma desvantagem em caso de acidente com modos não vulneráveis, por isso, sempre que possível, deve ser segregada. Outro aspecto peculiar ocorreu durante o aumento do número de automóveis na Europa, nas décadas de 1950 e 1960, que elevou o número de óbitos de ciclistas devido às desvantagens experimentadas pelo uso da bicicleta em espaço compartilhado com os usuários motorizados (GTZ, 2009).

\subsection{Ações para Amenizar a Acidentalidade}

Há três fatores os quais constituem os sistemas de trânsito: ser humano, veículo e via. Quando a interação entre esses fatores não ocorre de maneira satisfatória pode ocorrer um acidente. A segurança no transporte envolve diversas áreas e para a redução da acidentalidade deve-se atuar em seis delas: Engenharia, Educação, Esforço Legal, Engajamento, Ambiente e Avaliação. Para este trabalho, serão analisadas apenas três áreas: Engenharia, Educação e Esforço Legal, que estão resumidas a seguir (FERRAZ, RAIA JUNIOR, et al., 2012)

Engenharia: atua na melhoria da segurança no trânsito. Nessa área, estão incluídas melhorias na engenharia viária e de tráfego, englobando projetos, sinalização, análise de pontos críticos, dispositivos de fiscalização, manutenção das vias, medidas de redução e controle da velocidade e melhoria de iluminação. O melhoramento das tecnologias veiculares também é responsável pela diminuição de acidentes e da gravidade dos mesmos. Equipamentos como Air Bag e sistema de freios ABS são exemplos de tecnologias que colaboram para o aumento da segurança no trânsito. O uso de medidas de Traffic calming, medidas para induzir 
motoristas a andarem mais devagar de forma integrada a outros modos e dando prioridade sempre ao pedestre, também criam áreas em que há um acréscimo na segurança.

Educação: atua na conscientização da população para respeitar as leis e a sinalização de trânsito e na capacitação das pessoas de forma adequada, prevendo reciclagens periódicas. A educação deve começar desde cedo, no colégio, para que todo cidadão, condutor ou não, tenha conhecimento das leis de trânsito. Essa área engloba também campanhas educativas na mídia.

Esforço Legal: atua no cumprimento da legislação, fiscalizando o trânsito e punindo irregularidades. A documentação dos acidentes também é responsabilidade dessa área que é fundamental para que sejam analisados dados para a melhoria da segurança e da mobilidade. 


\section{MÉTODO}

Uma das partes essências desta pesquisa foi apresentada na seção anterior, a qual constituiu em uma revisão bibliográfica, indispensável para o entendimento da evolução histórica dos deslocamentos humanos, e também da evolução do conceito de planejamento urbano e, por fim, a proposta de avaliação, objetivo deste trabalho. Diante do novo paradigma, voltado ao ser humano, o planejamento urbano precisa de ferramentas que avaliem o sistema com esse ponto de vista. Com a pesquisa também se pode avaliar diferentes modos e suas características e, assim, selecionar grupos a serem analisados para a avaliação da condição do UV diante à mobilidade urbana.

Sendo o ser humano o foco para a sustentabilidade do sistema, procurou-se privilegiá-lo, agrupando dentro do estudo os usuários de acordo com a escala necessária ao seu deslocamento. Essas inadequações de escala envolvem dimensões físicas e massa, mas, também, envolvem diferenças de velocidade e, principalmente, vulnerabilidade, já que no escopo deste trabalho a prevalência de agravos, entre usuários vulneráveis em relação aos não vulneráveis, é usado, como um indicador da adequação do homem ao meio urbano. Esta escolha buscou um procedimento seguro, já consagrado em estudos de acidentologia, tanto em comparações espaciais como temporais, e que permitisse focar, preferencialmente, a segurança do UV. A Razão de Prevalências (RP) entre UVs e UNVs permite calcular o risco de uma situação quando o fator de exposição não está presente. Assim, pode-se definir a RP como uma medida de Risco Relativo (RR) que indica o quanto é provável que um indivíduo, que está exposto ao fator estudado, venha a sofrer determinada situação (MEDRONHO, 2007; ELVIK, 1996; ZAMBON, et al. 2006; GEHL, 2012).

Em se tratando de segurança nos transportes, pode-se determinar a possibilidade do usuário de um determinado modo sofrer agravo em relação a um usuário não exposto (ELVIK, 1993; KIM et al, 2003). Vale lembrar que a RP, também conhecida como Razão de Odds, é uma ferramenta muito eficaz para análises comparativas de risco entre dois grupos, que não precisam pertencer ao mesmo conjunto, como estudos de antes e depois ou mesmo de comparação entre diferentes locais (MIETTINEN, 1985).

Esta comparação entre o grupo de Caso e Controle por meio da RP é uma estimativa da relação de segurança entre os usuários. Apesar de o fator de exposição não ser considerado 
neste cálculo, ainda assim é possível realizar a comparação entre os grupos, uma vez que se analisam internamente apenas as razões entre expostos e não expostos, pois se busca o risco relativo entre os usuários. É provável que o efeito confounding de uma provável mudança quantitativa no fluxo se dissipe entre as variáveis escolhidas para determinar a prevalência, ou seja, um maior desenvolvimento econômico produz um aumento no número de viagens de carro, de ônibus e, provavelmente, de viagens a pé e de bicicleta, com consequências no número de conflitos e acidentes. Sob uma condição de aumento de fluxo, se as demais condições forem mantidas, é provável que haja um aumento de ocorrências tanto em UVs como em UNVs. No entanto, se for observada uma variação nas razões ao longo do processo, esta indicará uma provável variação nos padrões de segurança relativo.

Cabe aqui esclarecer alguns aspectos da técnica usada para avaliação do risco relativo ou Cálculo de Prevalência (CP). O CP é utilizado para comparar o número de agravos fatais do grupo exposto em relação ao grupo não exposto, ou seja, se estamos calculando a prevalência de óbitos no grupo pedestres, fazemos a razão entre os óbitos pedestres por óbitos não pedestres (ciclistas, motociclistas, usuários de automóveis ou ônibus). Normalmente, é do interesse da segurança viária, chegar a uma tomada de decisão rápida a respeito de medidas e contramedidas de segurança de trânsito, a expressão abaixo é normalmente utilizada para isso.

Cálculo da Prevalência $(\mathrm{CP})=\frac{\text { Usuário Exposto }(U E)}{\text { Usuário Não Exposto }(U N E)}$

Ao se adaptar para o caso da avaliação da condição do UV em relação ao UNV, a equação utilizada torna-se:

Cálculo da Prevalência $(\mathrm{RP})=\frac{\text { Usuário Vulnerável }(U V)}{\text { Usuário Não Vulner }(U N V)}$

Na Equação 4.1, normalmente, o termo UE corresponde ao somatório de acidentes que podem ser influenciados por uma determinada medida, já os UNE correspondem aos somáticos dos que não são influenciados. Esse procedimento permite trabalhar com dados de número de acidentes como probabilidades, além disso, também é possível realizar o somatório dos acidentes por quilômetro viajado (índices). Dependendo do problema que se está tratando, nesse caso UV e UNV, o fator de exposição não fica tão óbvio assim. A forma de tratamento a qual se tem uma razão e não uma proporção, da maneira colocada, na Equação 4.2, caso 
(numerador), não caso (denominador), é definida na literatura como odds de prevalência ou Cálculo de Prevalência conforme utilizado acima. Uma meta-análise, realizada com 26 estudos, mostra a regularidade com que esse procedimento é usado e seu potencial de análise (ELVIK, 1996). Isso se deve ao fato de facilitar a tomada de decisão de curto prazo. Normalmente, quando são realizados estudos, antes e depois, são verificados os dados de 1 ano e meio, antes e depois de alguma intervenção, porém, pode-se avaliar anualmente a evolução local ou a comparação entre dois locais, ou até intervalos menores, se o número de ocorrências for elevado. No entanto, quanto mais anos forem analisados, mais ocorrências devem aparecer, tornando mais eficaz a análise da tendência dos acidentes tendo em vista o comportamento de oscilação da acidentalidade (HSM, 2010).

O segundo artifício matemático é o cálculo da RP, a qual é o cerne da comparação entre dois grupos a avaliar, podendo ser tanto em uma análise temporal como em uma espacial. Neste trabalho, essa ferramenta será utilizada para acompanhar a evolução, ano a ano, entre os grupos de UVs em relação ao UNVs. A RP se resume, de modo geral, como a razão entre dois $\mathrm{CP}$, um representando o Caso e outro o Controle, como mostra a Equação 4.3. A composição do Caso e Controle varia conforme o que se visa analisar, pois, por meio desta ferramenta, é possível comparar as ocorrências em períodos ou áreas diferentes. Quando se compara diferentes períodos no tempo, podemos entender o uso da ferramenta Caso e Controle pela Figura 12. Além de um ponto fixo definido no tempo, por uma intervenção, pode-se analisar a evolução ano a ano devido a diversas melhorias feitas nesse período.

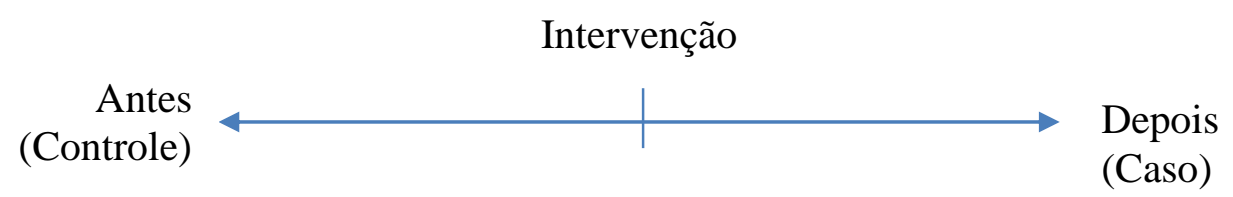

Figura 12 - Demonstração Antes e Depois

$R P=\frac{C P_{\text {Caso }}}{C P_{\text {Controle }}}$

Sendo:

$R P$ - Razão de Prevalência do grupo estudado;

$C P_{\text {Caso }}$ - Cálculo de Prevalência do grupo determinado como Caso;

$C P_{\text {Controle }}$ - Cálculo de Prevalência do grupo determinado como Controle; 
O resultado decorrente da RP mostrará a tendência de comportamento do grupo analisado, o qual será utilizado para interpretar o cenário de estudo e qualificá-lo de acordo com a situação.

- Quando o resultado da RP for abaixo de 1 (um), indicará que o grupo representado pelo Caso experimentou um risco relativo menor que o Controle;

- Quando o resultado da RP foi igual a 1 (um), então não há diferença significativa nos dados analisados, indicando um aumento ou diminuição do risco experimentado entre o grupo de usuários do Caso e Controle;

- Quando o resultado da RP superior a 1 (um), indicará que o grupo representado pelo Caso experimentou um risco relativo maior que o Controle;

Para o uso da ferramenta é necessário dispor de dados confiáveis e de fácil acesso. Este trabalho buscou diversos bancos de dados locais e nacionais. Constatou-se uma dificuldade na obtenção desse tipo de informação, na qual os órgãos parecem ter medo de disponibilizar os dados, mesmo para fins de pesquisa, muitas vezes exigindo um excesso de burocracia. Foi utilizado o banco de dados do Ministério da Saúde, o Datasus, o qual se mostrou uma ferramenta de fácil aplicação, a qual fornece acesso rápido aos dados necessários ao cálculo nesse procedimento e nele estão registrados todas as internações e óbitos ocorridos nos centros de saúde brasileira de forma desagregada.

Sendo o banco de dados provido de ferramentas de pesquisa, podem-se filtrar os dados para se ter uma ideia global sobre a mortalidade no trânsito, no espaço e no tempo. Na pesquisa, é possível escolher a opção do local de ocorrência, tipo de veículo envolvido, período de acordo com a necessidade de dados que se pretende avaliar. Os dados do Ministério da Saúde podem ser acessados na página do Datasus, em que estão disponíveis as informações de Saúde (TABNET). Analisando os óbitos provocados por causas externas, podem-se escolher os parâmetros desejados conforme layout das Figuras 12 e 13. 


\begin{tabular}{l}
\hline O DATASUS \\
\hline Informaçōes de Saúde \\
\hline [TABNET] \\
Indicadores de Saúde \\
Assistência à Saúde \\
Epidemiológicas e \\
Morbidade \\
Rede Assistencial \\
Estatísticas Vitais \\
Demográficas e \\
Socioeconômicas \\
Inquéritos e Pesquisas \\
Saúde Suplementar \\
Estatísticas de acesso ao \\
TABNET \\
\hline Informações de Saúde (BI) \\
\hline Informações Financeiras \\
\hline Sistemas e Aplicativos \\
\hline Políticas \\
\hline Publicações \\
\hline Serviços
\end{tabular}

$\underline{\text { Início }}$ : Informações de Saúde (TABNET) : Estatisticas Vitais

Escolha uma opção:

Nascidos vivos - 1994 a 2011

Nascidos vivos

Mortalidade - 1996 a 2011, pela CID-10

Mortalidade geral

Óbitos infantis

Óbitos de mulheres em idade fértil e óbitos maternos

$\odot$ Óbitos por causas externas

Óbitos fetais

Correçăo e Redistribuiçăo de Óbitos

Mortalidade - 1979 a 1995, pela CID-9

Mortalidade geral

Óbitos infantis

Óbitos por causas externas

Óbitos fetais

Outras tabulaçōes de mortalidade

Completitude dos principais campos - SIM

Completitude de campos relacionados aos dados da mãe em óbitos Fetais e Menores de 1 ano

Completitude do campo Circunstância do óbito por Causas Externas Causas mal definidas

Câncer (sítio do Inca)

Atlas de Mortalidade por Câncer

Figura 13 - TABNET DATASUS - Pesquisa e filtros dos dados 


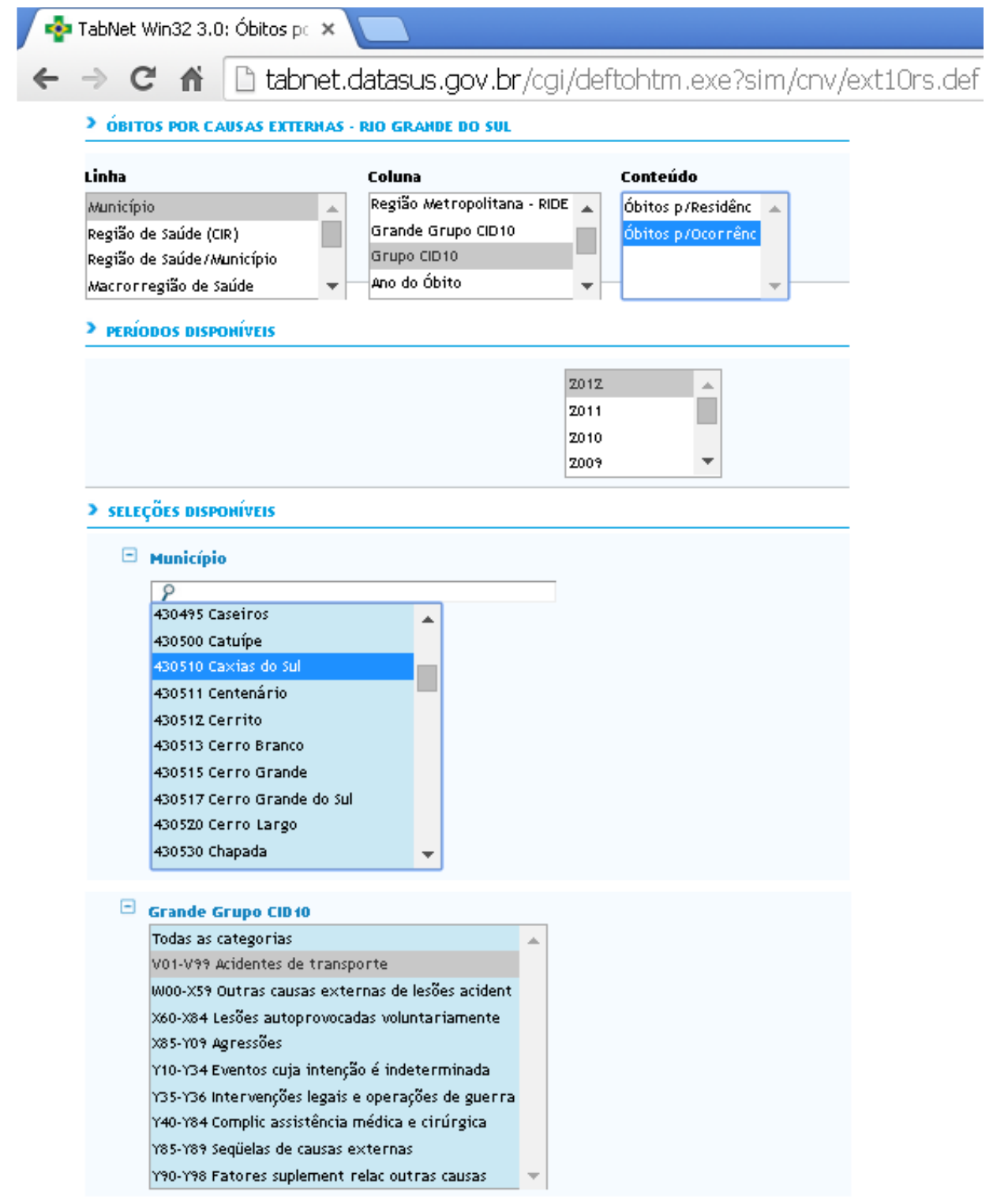

Figura 14 - TABNET DATASUS - Pesquisa e filtros dos dados

Este trabalho analisa os dados de óbitos provocados por acidentes de transporte na cidade em questão, separados por tipo de usuários que vieram a falecer nos anos determinados. O estudo de acidentes de trânsito deve abranger um período de, no mínimo, um ano, porém uma análise ano a ano é o ideal para pesquisar o efeito da evolução da segurança viária diante da mudança de paradigma. Diante do período que o Ministério da Saúde leva para tabular os dados e disponibilizá-los, optou-se por analisar a evolução da acidentalidade nos últimos 6 anos de dados disponíveis, ou seja, 2006 a 2012.

Atualmente, diversos índices são utilizados para demonstrar a evolução de acidentes ao longo do tempo. Um dos mais utilizados é o número de óbitos por 100.000 veículos registrados, esse 
índice faz uma pequena relação com a exposição, pois acredita-se que quanto mais veículos registrados mais veículos circularão. Diante disso, este índice foi escolhido para comparar a evolução da acidentalidade com o método da razão de prevalências apresentado acima.

\subsection{Frota de veículos}

Buscando avaliar a variação da exposição no trânsito, verificou-se a variação da frota de veículos para se ter uma ideia do aumento da exposição para cada modo. Tendo em vista que o transporte público é o mais seguro e sustentável, o aumento nesse uso deveria gerar uma melhoria na segurança e a variação no uso foi coletada na prefeitura local. Para o uso da motocicleta é possível analisar no site do DENATRAN, o qual possui um banco de dados acessível a todo cidadão, no qual expõe a frota de veículos ano a ano, classificada por tipo. Seguem dados conforme visualizados no site do DENATRAN.

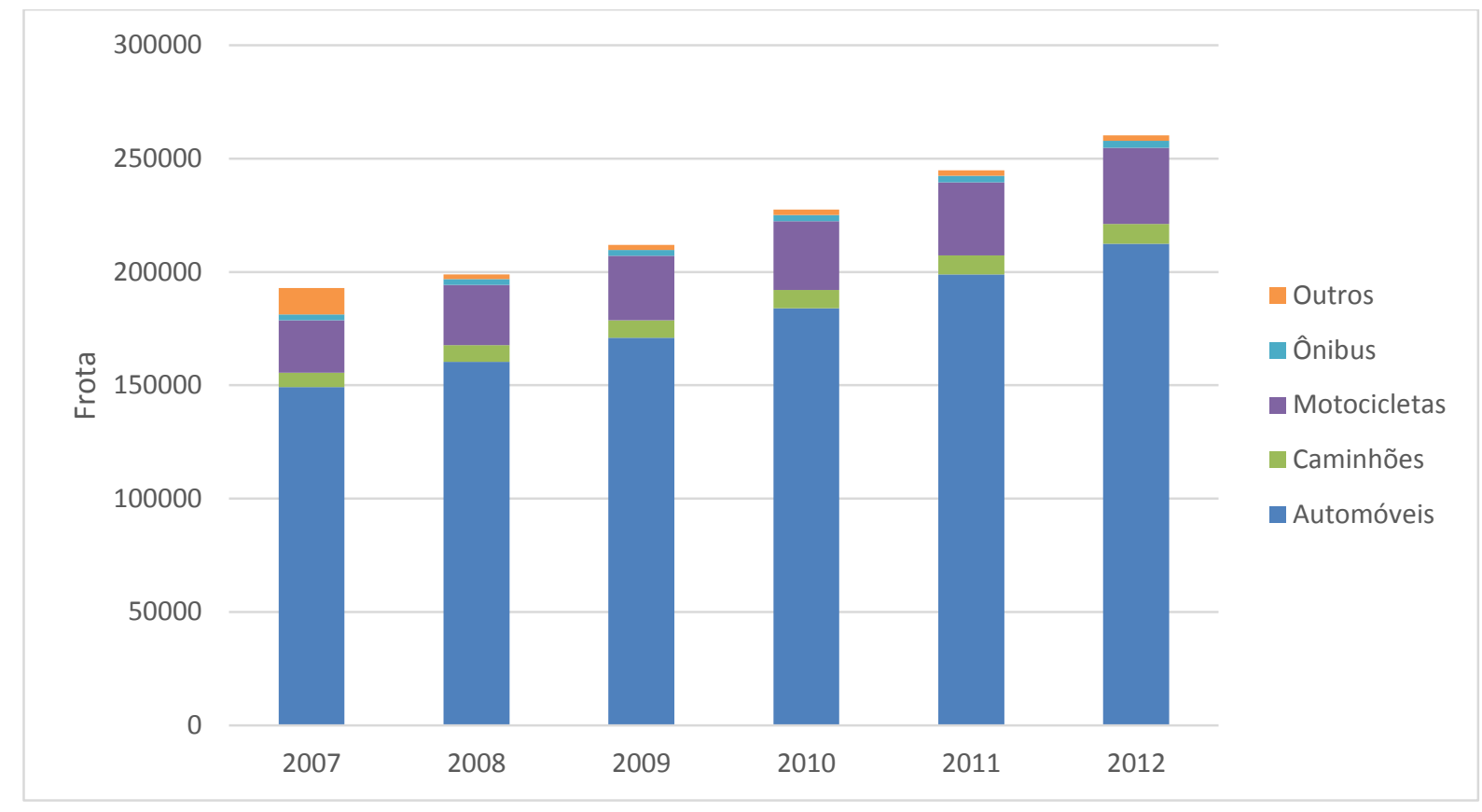

Figura 15 - Evolução da Frota no Município de Caxias do Sul

A Figura 14 mostra o crescimento da frota de veículos no município de Caxias do Sul, no período de 2007 a 2012. O DENATRAN possui uma classificação por tipo de veículo, porém, para a análise deste trabalho, alguns dados foram agrupados e outros desconsiderados. Os que foram agrupados: 1) Automóveis, Utilitários, Caminhonetes e Camionetas, 2) Motocicletas, Motonetas e Ciclomotores; e os que foram excluídos: outros, tratores e reboques, por não influenciar no trânsito urbano. 


\subsection{Comparação do tempo de viagem por modo}

Sendo o tempo de viagem uma variável que impacta muito na escolha modal, buscou-se analisar a diferença entre os modos para realizar o mesmo itinerário na cidade. Para a obtenção do tempo de volta do transporte coletivo foi utilizado o tempo da planilha horária do TPU, já o tempo para veículos particulares, motocicleta e automóvel, foi levantado in loco.

Buscando melhorar a condição do UV, diante o novo paradigma da mobilidade sustentável, segue o resumo dos indicadores a serem analisados:

Tabela 8 - Resumo dos Indicadores

\begin{tabular}{|c|c|c|c|}
\hline & Grupo & Indicador & Descrição \\
\hline I & Segurança & 1 & Razão de Prevalências dos UN em relação aos UNV \\
\hline \multirow[t]{2}{*}{ II } & Motorizados & 2 & Uso do TPU \\
\hline & & 3 & Uso da Motocicleta \\
\hline \multirow[t]{3}{*}{ II } & Comparação & 4 & Tempo de Viagem Carro x Moto x Ônibus \\
\hline & Tempo & & \\
\hline & Viagem & & \\
\hline
\end{tabular}

As análises realizadas, na próxima seção, são balizadas de acordo com as teorias que embasam o Novo Urbanismo, Crescimento Inteligente e Movimento de Comunidades Habitáveis, todas elas aplicadas a partir do método TOD, ver Seção 4. 


\section{RESULTADOS E ANÁLISES}

Nesta seção são apresentados os resultados e análises obtidas a partir da metodologia proposta. Inicialmente será descrita a área de estudo usada para ilustrar e tornar prática a abordagem.

\section{1 Área de Estudo}

O estudo de caso foi realizado na cidade de Caxias do Sul, no estado do Rio Grande do Sul, Brasil. A cidade está localizada na região da serra gaúcha e possui população de 465.304 habitantes, estimativa do IBGE. Caxias do Sul é o segundo polo metal mecânico do estado, além de estar entre os maiores produtores de vinhos do estado. O TPU é realizado pela empresa Viação Santa Teresa de Caxias do Sul, a qual venceu licitação de concessão em 1999. Atualmente existem 80 linhas de ônibus nas quais circulam 344 veículos de tamanhos variados, Midibus, Padron e Especiais (articulados). Mensalmente, o transporte público transporta cerca de 4.000.000 de usuários. Sendo considerada uma cidade rica, Caxias do Sul possui alto índice de motorização particular, sendo que possui 1,80 pessoas por veículos.

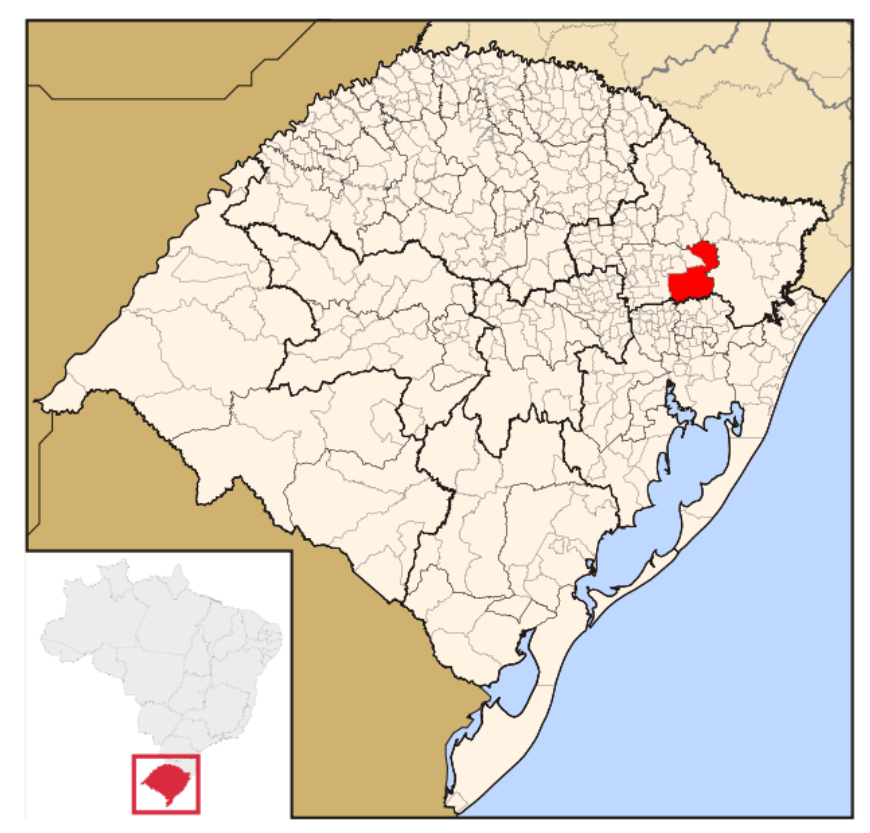

Figura 16 - Localização de Caxias do Sul

O município de Caxias do Sul possui uma extensa área rural. Seu perímetro urbano é cortado por uma rodovia Federal e duas rodovias Estaduais, essas encontram-se inseridas no dia a dia 
da maioria dos cidadãos caxienses. Segue Tabela 9 mostrando relação entre os segmentos urbanos e rurais de cada rodovia e após o mapa demonstrativo.

Tabela 9 - Rodovias que cruzam a cidade de Caxias do Sul

\begin{tabular}{llll}
\hline Rodovia & $\begin{array}{l}\text { Trecho Urbano } \\
(\mathbf{k m})\end{array}$ & Trecho Rural $(\mathbf{k m})$ & Total $(\mathbf{k m})$ \\
\hline BR 116 & 38,6 & 19,1 & \\
\hline RS 453 & 42,1 & 27,8 & 57,7 \\
RS 122 & 5,3 & 10,1 & 69,9 \\
\hline
\end{tabular}

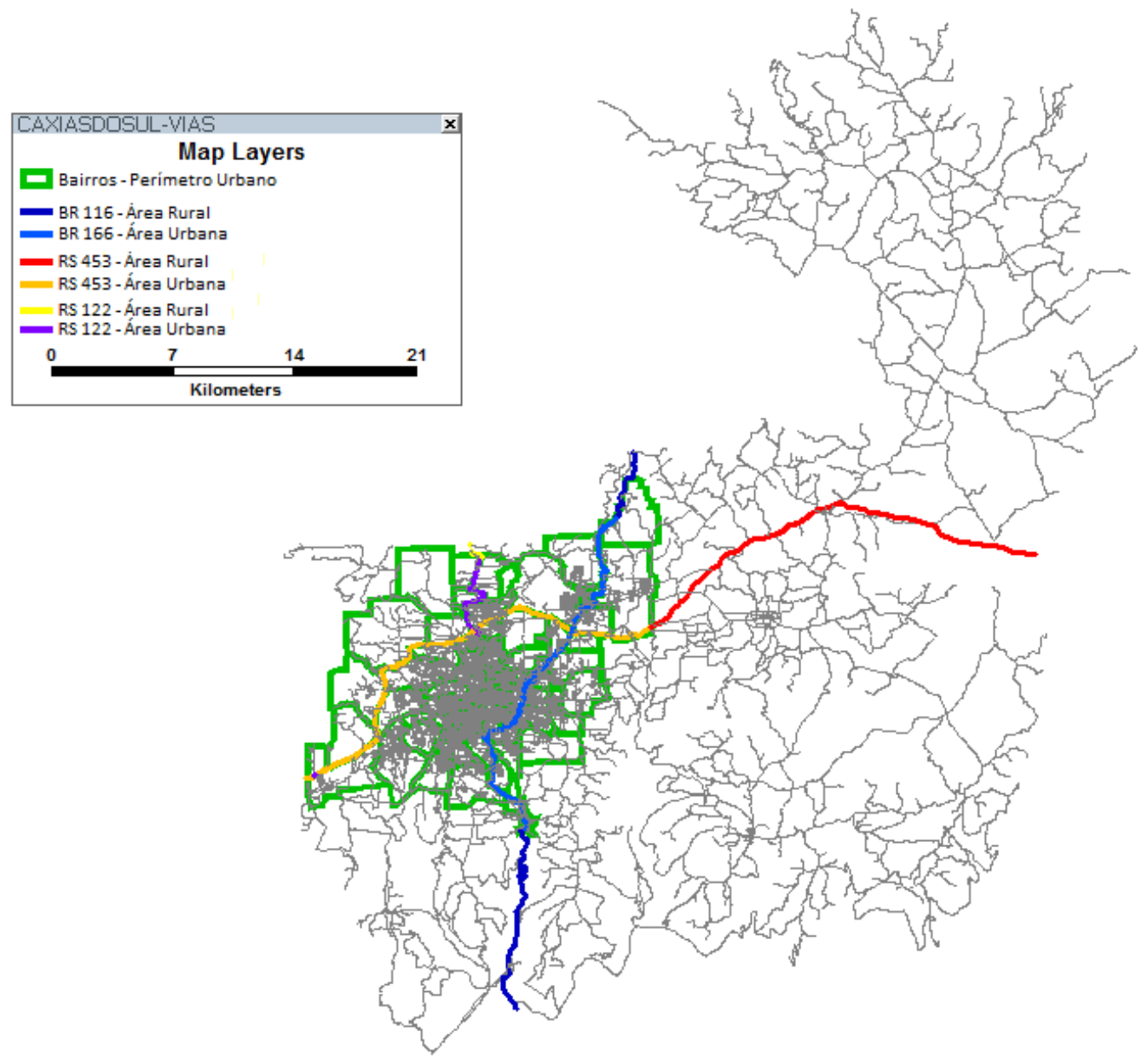

Figura 17 - Delimitação do perímetro urbano e Rodovias que influenciam nos deslocamento urbanos

O mapa demonstra todas as vias do município analisado, tanto no perímetro urbano como na área rural. A área contornada pela cor verde é a delimitação do perímetro urbano e as rodovias estão grifadas com cores diferenciadas para demostrar o segmento urbano ou rural em que estão inseridas, conforme legenda. 


\subsection{Acidentalidade}

Utilizando o banco de dados do ministério da saúde, o Datasus, foram pesquisados os óbitos referentes ao transporte no município ao longo de 6 anos. Seguem os dados:

, ÓBITOS POR CaUSAS EXTERNAS - RIO GRANDE DO SUL

\begin{tabular}{|c|c|c|c|c|c|c|c|}
\hline Grupo CID10 & 2007 & 2008 & 2009 & 2010 & 2011 & 2012 & Total \\
\hline TOTAL & 65 & 88 & 88 & 86 & 96 & 70 & 493 \\
\hline Acidentes & 65 & 88 & 88 & 86 & 96 & 70 & 493 \\
\hline Acidentes de transporte & 65 & 88 & 88 & 86 & 96 & 70 & 493 \\
\hline ... Pedestre traumatizado em um acidente de transp & 20 & 28 & 19 & 17 & 29 & 20 & 133 \\
\hline ... Ciclista traumatizado em um acidente de transp & - & 2 & 2 & 1 & 3 & 1 & 9 \\
\hline ... Motociclista traumat em um acidente de transpo & 9 & 14 & 25 & 30 & 28 & 26 & 132 \\
\hline ... Ocupante automóvel traumat acidente transporte & 31 & 38 & 35 & 31 & 28 & 18 & 181 \\
\hline ... Ocupante caminhonete traumat acidente transpor & - & - & 1 & 2 & 2 & - & 5 \\
\hline$\ldots$ Ocupante veíc transp pesado traumat acid trans & 3 & 1 & 3 & 3 & 2 & 2 & 14 \\
\hline ... Ocupante ônibus traumat acidente de transporte & - & - & - & - & - & 1 & 1 \\
\hline ... Outros acidentes de transporte terrestre & 2 & 4 & 3 & 2 & 4 & 2 & 17 \\
\hline ... Outros acidentes de transporte e os näo especi & - & 1 & - & - & - & - & 1 \\
\hline
\end{tabular}

Fonte: MS/SVS/CGIAE - Sistema de Informaçëes sobre Mortalidade - SIM

Consulte o site da Secretaria Estadual de Saúde para mais informaçöes.

Nota:

Em 2011, houve uma mudança no conteúdo da Declarą̧ăo de Óbito, com maior detalhamento das informaçöes coletadas. Para este ano, foram utilizados simultaneamente os dois formulários. Para mais detalhes sobre as mudanças ocorridas e os

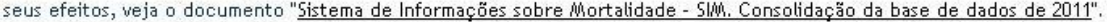

Figura 18 - Óbitos devido acidentes de trânsito na cidade de Caxias do Sul entre os anos de 2007 e 2012. Fonte: DATASUS 
Com os dados do Governo Federal, pode-se analisar os óbitos por tipo de usuário. Como os dados estão divididos por tipo de usuário é fácil classificá-los nos grupos a serem analisados, UV e UNV. Para analisar a evolução dos óbitos, os mesmo foram agrupados nas classes definidas ano a ano. Com os dados, é possível verificar a evolução histórica dos dois grupos de usuários. Segue tabela com dados agrupados e cálculo das Prevalências:

Tabela 10 - Classificação dos óbitos em UV e UNV

\begin{tabular}{|c|c|c|c|c|c|c|c|c|c|c|c|c|}
\hline MODO & 2007 & UV e UNV & 2008 & UV e UNV & 2009 & UV e UNV & 2010 & UV e UNV & 2011 & UV e UNV & 2012 & UV e UNV \\
\hline Pedestre & 20 & & 28 & & 19 & & 17 & & 29 & & 20 & \\
\hline Ciclista & 0 & 29 & 2 & 44 & 2 & 46 & 1 & 48 & 3 & 60 & 1 & 47 \\
\hline Motocicleta & 9 & & 14 & & 25 & & 30 & & 28 & & 26 & \\
\hline Automóvel & 31 & & 38 & & 35 & & 31 & & 28 & & 18 & \\
\hline Caminhonete & 0 & & 0 & & 1 & & 2 & & 2 & & 0 & \\
\hline Veículo Pesado & 3 & 34 & 1 & 39 & 3 & 39 & 3 & 36 & 2 & 32 & 2 & 21 \\
\hline Ônibus & 0 & & 0 & & 0 & & 0 & & 0 & & 1 & \\
\hline Outros & 2 & - & 5 & - & 3 & - & 2 & - & 4 & - & 2 & - \\
\hline TOTAL & 65 & & 88 & & 88 & & 86 & & 96 & & 70 & \\
\hline
\end{tabular}

\section{CÁLCULO DE PREVALÊNCIAS}

2007

Óbitos de UV $=29$

Óbitos de UNV $=34$

Cálculo da Prevalência:

$C P_{2007}=\frac{U V}{U N V}=\frac{29}{34}=0,85$
2008

Óbitos de UV $=44$

Óbitos de UNV $=39$

Cálculo da Prevalência:

$C P_{2008}=\frac{U V}{U N V}=\frac{44}{39}=1,13$
2009

Óbitos de UV $=46$

Óbitos de UNV $=39$

Cálculo da Prevalência:

$$
C P_{2009}=\frac{U V}{U N V}=\frac{46}{39}=1,18
$$


2010

Óbitos de UV $=48$

Óbitos de UNV $=36$

Cálculo da Prevalência:

$$
\begin{aligned}
C P_{2010}=\frac{U V}{U N V} & =\frac{48}{36} \\
& =1,33
\end{aligned}
$$

2011

Óbitos de UV $=60$

Óbitos de UNV $=32$

Cálculo da Prevalência:
2012

Óbitos de UV $=47$

Óbitos de UNV $=21$

Cálculo da Prevalência:

$$
\begin{aligned}
C P_{2012}=\frac{U V}{U N V} & =\frac{47}{21} \\
& =2,24
\end{aligned}
$$

\section{RAZÃO DE PREVALÊNCIAS}

$$
\begin{aligned}
& R P_{2008 / 2007}=\frac{P_{2008}}{P_{2007}}=\frac{1,13}{0,85}=1,32 \\
& R P_{2011 / 2010}=\frac{P_{2011}}{P_{2010}}=\frac{1,87}{1,33}=1,41 \\
& R P_{2009 / 2008}=\frac{P_{2009}}{P_{2008}}=\frac{1,18}{1,13}=1,04 \\
& R P_{2012 / 2011}=\frac{P_{2012}}{P_{2011}}=\frac{2,24}{1,87}=1,19 \\
& R P_{2010 / 2009}=\frac{P_{2010}}{P_{2009}}=\frac{1,33}{1,18}=1,13
\end{aligned}
$$

Tabela 11 - Resumo dos cálculos de CP e RP

\begin{tabular}{ccc}
\hline Ano & CP & RP \\
\hline $\mathbf{2 0 0 7}$ & 0,85 & 1,32 \\
$\mathbf{2 0 0 8}$ & 1,13 & \\
$\mathbf{2 0 0 9}$ & 1,18 & 1,05 \\
$\mathbf{2 0 1 0}$ & 1,33 & 1,13 \\
$\mathbf{2 0 1 1}$ & 1,88 & 1,41 \\
$\mathbf{2 0 1 2}$ & 2,24 & 1,19 \\
\hline
\end{tabular}

Para uma análise mais desagregada dos dados, fez-se o CP dos UV de forma separada, comparando assim isoladamente a variação do risco relativo dos pedestres, ciclistas e motociclistas diante o UNV utilizando método da RP. Nas Tabelas 12, 13 e 14 é possível observar os resultados obtidos. 
Tabela 12 - Cálculo da Prevalência Pedestres/UNV

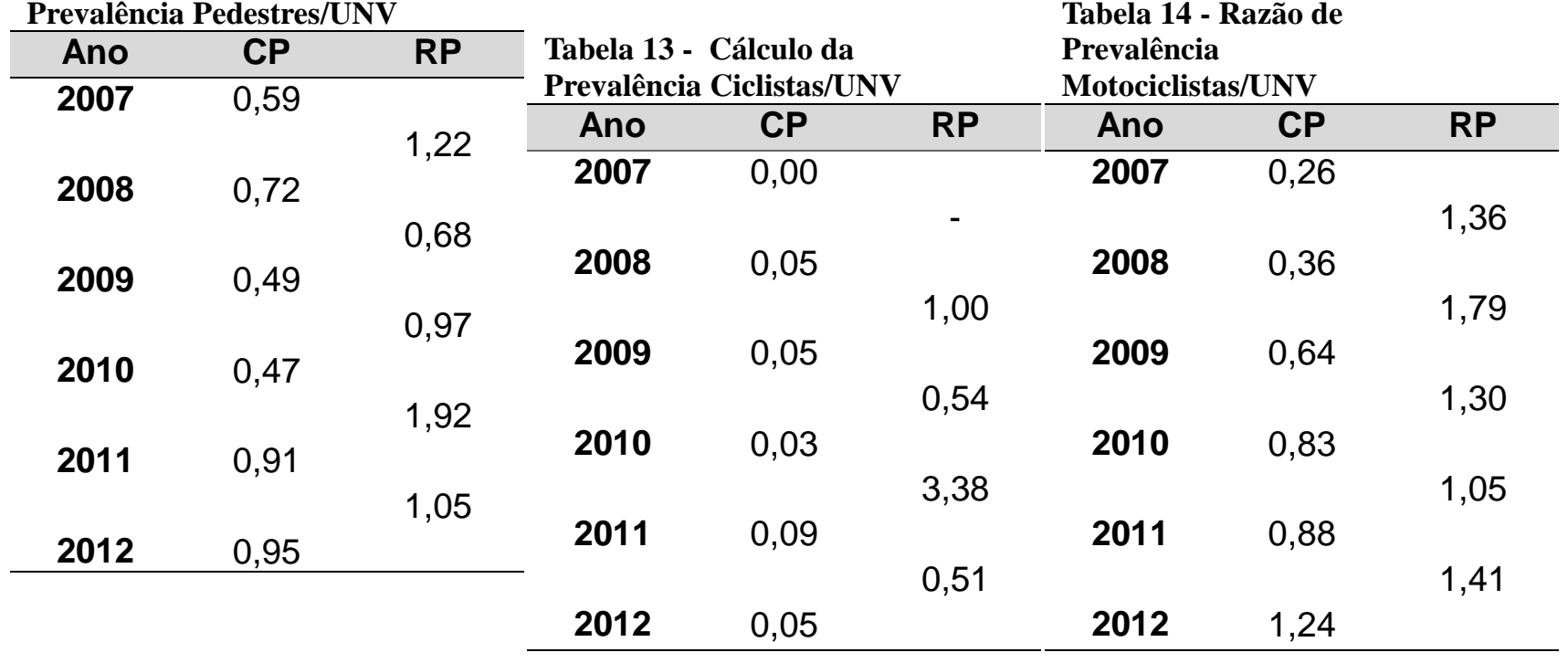

Para uma avaliação comparativa, buscou-se a criação de índices de óbitos por 100.000 veículos. Este é um dos índices mais utilizados em análises de risco no trânsito, quando não se têm dados de fluxo, conforme mostra a Figura 19.

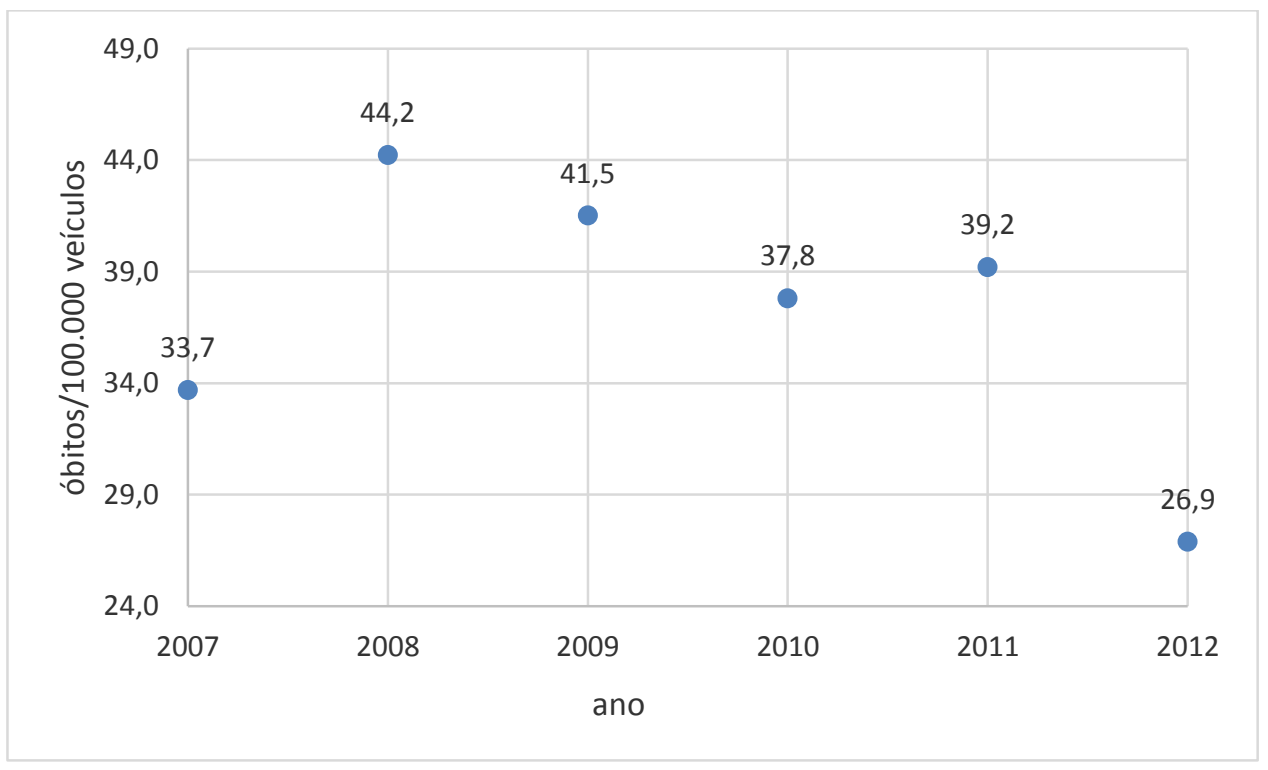

Figura 19 - Índice de óbitos/100.000 veículos em Caxias do Sul

A facilitação, por parte do governo, nos últimos anos, por financiamento de veículos elevou muito o crescimento da frota de veículos individuais, principalmente devido à má qualidade do transporte público que, em alguns casos, obriga a busca desse tipo de solução. Analisando a evolução do índice de óbitos por 100.000 veículos, constata-se uma tendência decrescente, provavelmente, indicando uma melhora no âmbito da acidentalidade viária. Apesar de nos anos de 2007 e 2008 o aumento ter sido grande, para os anos seguintes houve uma tendência 
de diminuição no índice.

A Tabela 11 mostra que o grupo UV é mais afetado do que o grupo UNV, ao longo do período de análise. Na série de RPs, calculadas ano a ano, estes apresentam sempre valores maiores que 1, demonstrando um aumento do risco relativo experimentado pelo grupo mais vulnerável. O quadro de Caxias do Sul não é diferente de outras cidades no Brasil e no mundo. Países como EUA e Holanda estão enfrentando o fenômeno do crescimento da venda e do uso de motos, principalmente de pequeno porte, com impacto importante na acidentalidade. Este fenômeno deve ser analisado com atenção, por parte do poder concedente e dos operadores de transporte público, pois mostra a importância do tempo de viagem para o usuário. Em locais onde ocorre o mototaxismo, muitas vezes o usuário paga mais, enfrenta os riscos inerentes e o desconforto de uma garupa de motocicleta, motivado apenas pelo ganho de tempo.

Para se ter uma ideia do impacto de cada modo no CP, segue a Figura 20 com uma análise desagregada da evolução dos acidentes, ao longo dos anos analisados.

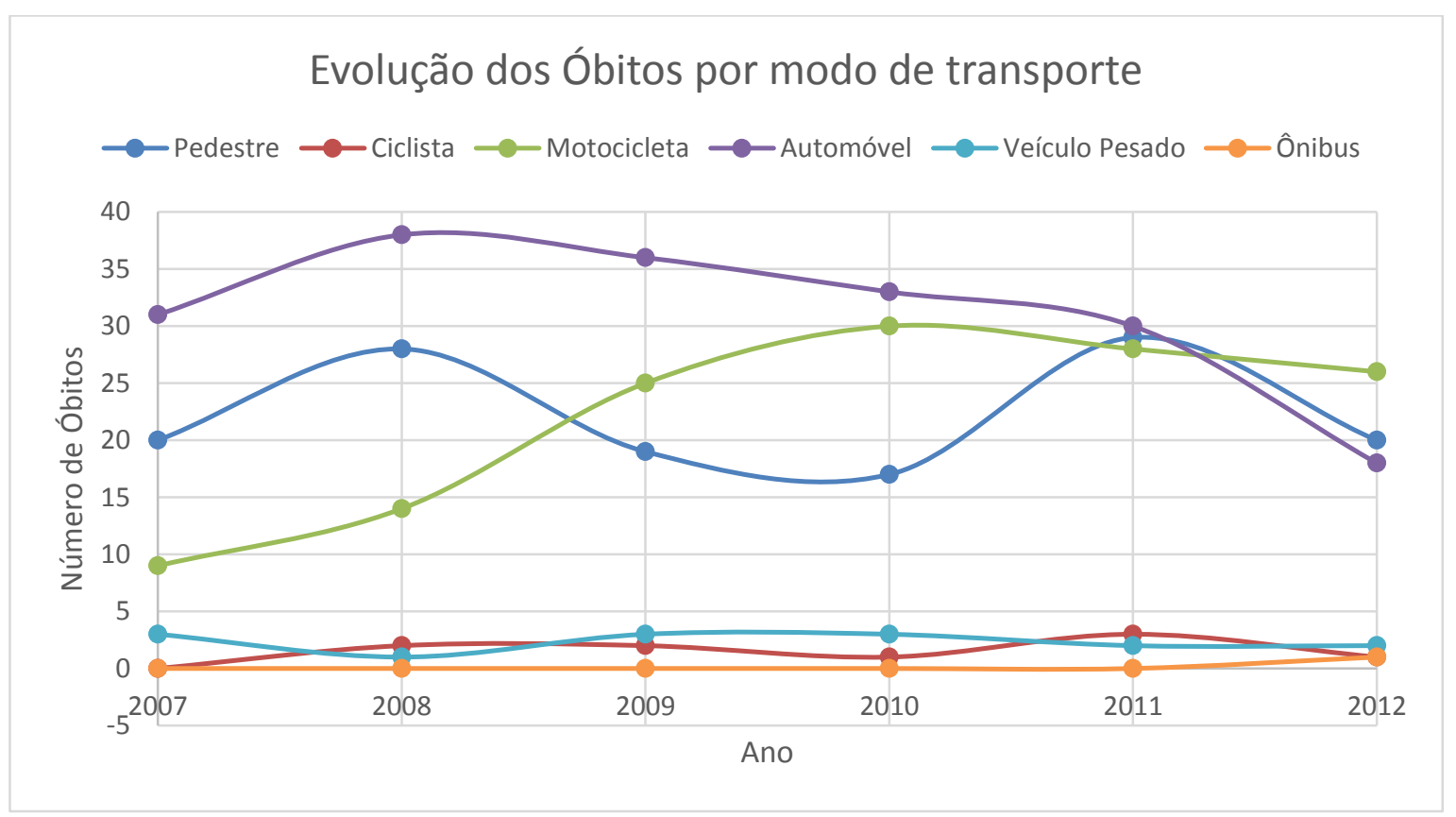

Figura 20 - Evolução dos óbitos em Caxias do Sul

Nota-se que os óbitos dos usuários de bicicletas e veículos pesados se mantêm sem variações significativas, no caso da bicicleta os resultados devem ser vistos com uma reserva, dada a pouca utilização do veículo atualmente. Para o usuário de automóvel, houve uma redução substancial do número de óbitos, indo de 38, em 2008, para 18 óbitos, em 2012. Para o caso 
do pedestre, esse índice apresenta uma oscilação típica de índices relacionados com acidentes de trânsito, observando-se uma tendência de regressão a média, obtendo uma média de 22 mortes durante o período analisado. O ônibus se mostrou ser muito seguro, pois apenas um óbito foi registrado no período. Para finalizar o grupo, a motocicleta apresentou um risco relativo crescente, tendo este aumentado de 9 óbitos, em 2007, para 30, em 2010, seguido de uma pequena queda.

A Tabela 11 mostrou o crescimento do RR do UV, e nas Tabelas 12, 13 e 14 pode-se verificar a análise do parágrafo anterior, aonde o RR do Motociclista aumentou muito mais do que dos demais UVs, ou seja, em todos, os anos analisados o motociclista teve seu risco aumentado. Apesar disso, é claro que houve períodos do crescimento do RR tanto do pedestre como do ciclista, porém houve reduções, o que não aconteceu para o motociclista.

\subsection{Uso do Transporte Público Urbano}

O cenário de estudo é um polo regional com uma economia bastante dinâmica; ao longo dos anos, a população aumenta e a economia se diversifica. Isso faz com que o perfil dos usuários se modifique. A Tabela 15 mostra a evolução dos dados do Transporte Público Urbano em Caxias do Sul.

Tabela 15 - Dados do Tranporte Público Urbano em Caxias do Sul (fonte: Prefeitura de Caxias do Sul e IBGE)

\begin{tabular}{ccccccc}
\hline $\begin{array}{c}\text { Revisão } \\
\text { Tarifária }\end{array}$ & IPKe & $\begin{array}{c}\text { Pass.Equiv } \\
\text { /Mês }\end{array}$ & $\begin{array}{c}\text { Pass.Totais } \\
\text { /Mês }\end{array}$ & Frota & Tarifa & População \\
\hline $\mathbf{2 0 0 3}$ & 2,4985 & 3.838 .512 & 4.172 .375 & 258 & $\mathrm{R} \$ 1,40$ & $376.970^{*}$ \\
\hline $\mathbf{2 0 0 4}$ & 2,1747 & 3.567 .126 & 3.987 .752 & 264 & $\mathrm{R} \$ 1,60$ & - \\
\hline $\mathbf{2 0 0 6}$ & 2,1448 & 3.611 .427 & 4.079 .954 & 266 & $\mathrm{R} \$ 1,80$ & - \\
\hline $\mathbf{2 0 0 7}$ & 2,1655 & 3.634 .668 & 4.127 .539 & 285 & $\mathrm{R} \$ 1,95$ & 399.038 \\
\hline $\mathbf{2 0 0 8}$ & 2,1491 & 3.715 .835 & 4.492 .246 & 313 & $\mathrm{R} \$ 2,20$ & - \\
\hline $\mathbf{2 0 1 0}$ & 2,0029 & 3.645 .138 & 4.716 .497 & 321 & $\mathrm{R} \$ 2,50$ & 435.564 \\
\hline $\mathbf{2 0 1 1}$ & 1,9299 & 3.618 .950 & 4.683 .265 & 333 & $\mathrm{R} \$ 2,70$ & - \\
\hline $\mathbf{2 0 1 2}$ & 1,8156 & 3.508 .962 & 4.589 .634 & 334 & $\mathrm{R} \$ 2,85$ & - \\
\hline $\mathbf{2 0 1 3}$ & 1,7860 & 3.428 .771 & 4.518 .996 & 338 & $\mathrm{R} \$ 2,75$ & - \\
\hline $\mathbf{2 0 1 4}$ & 1,7644 & 3.364 .931 & 4.474 .481 & 338 & $\mathrm{R} \$ 2,75$ & $499.484^{*}$ \\
\hline
\end{tabular}

*Estimativas 
De 2003 para 2014, houve o crescimento da população (em cerca de 32,5\%) e da malha urbana. Para o atendimento das comunidades mais periféricas, houve um crescente aumento de linhas de ônibus e de frota em circulação (31\%). Esse aumento não ocorreu na mesma proporção, se considerado o número de usuários. Apesar do número total ter crescido cerca de 7\% em 11 anos, o número de passageiros não pagantes subiu vertiginosamente, sendo que hoje cerca de $75 \%$ dos usuários sustentam o sistema, o que em 2003 correspondia a mais de 92\%. Mesmo com esforço do poder público por manter o valor da passagem mais atrativa, caso que ocorreu entre 2011 e 2014, o número de usuários continuou a diminuir, porém, estando a economia em alta e tendo um baixo número de desempregos, sabe-se que os usuários migraram para outros modos. Para a solução dos problemas acima e suas consequências, foi desenvolvida a metodologia TOD, a qual se preocupa em criar um ambiente capaz de atrair usuários a se fixar no entorno das instalações, garantindo a viabilidade e sustentabilidade do TPU, que oferece sustentabilidade urbana ao seu entorno.

\subsection{Uso da motocicleta}

Diante dos atrativos obtidos com o uso da motocicleta, ela se tornou uma alternativa ao transporte público de péssima qualidade. A Figura 21 mostra a evolução da frota no município de Caxias do Sul, com o intuito de identificar se há migração dos usuários do TPU para a motocicleta.

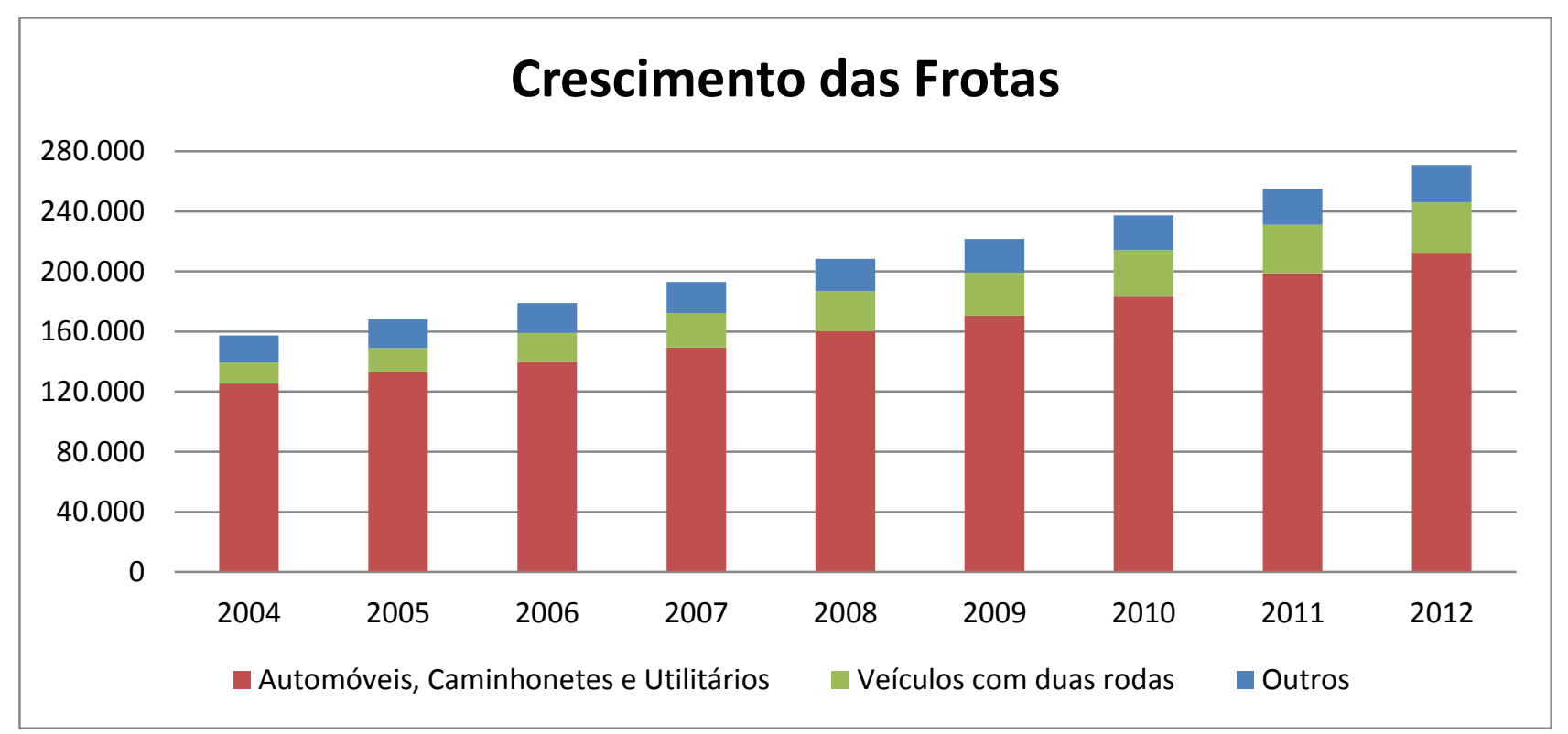

Figura 21 - Crescimento da Frota de Veículos Automotores em Caxias do Sul (fonte: DETRAN) 
Tabela 16 - Percentual da Frota por tipo de veículo

\begin{tabular}{c|c|c|c}
\hline Ano & Automóveis & $\begin{array}{c}\text { Duas } \\
\text { Rodas }\end{array}$ & Outros \\
\hline $\mathbf{2 0 0 4}$ & $79,73 \%$ & $8,85 \%$ & $11,42 \%$ \\
\hline $\mathbf{2 0 0 5}$ & $79,10 \%$ & $9,65 \%$ & $11,25 \%$ \\
\hline $\mathbf{2 0 0 6}$ & $78,11 \%$ & $10,83 \%$ & $11,06 \%$ \\
\hline $\mathbf{2 0 0 7}$ & $77,35 \%$ & $12,00 \%$ & $10,65 \%$ \\
\hline $\mathbf{2 0 0 8}$ & $76,91 \%$ & $12,71 \%$ & $10,38 \%$ \\
\hline $\mathbf{2 0 0 9}$ & $77,09 \%$ & $12,85 \%$ & $10,06 \%$ \\
\hline $\mathbf{2 0 1 0}$ & $77,47 \%$ & $12,78 \%$ & $9,75 \%$ \\
\hline $\mathbf{2 0 1 1}$ & $77,92 \%$ & $12,58 \%$ & $9,49 \%$ \\
\hline $\mathbf{2 0 1 2}$ & $78,38 \%$ & $12,37 \%$ & $9,25 \%$ \\
\hline
\end{tabular}

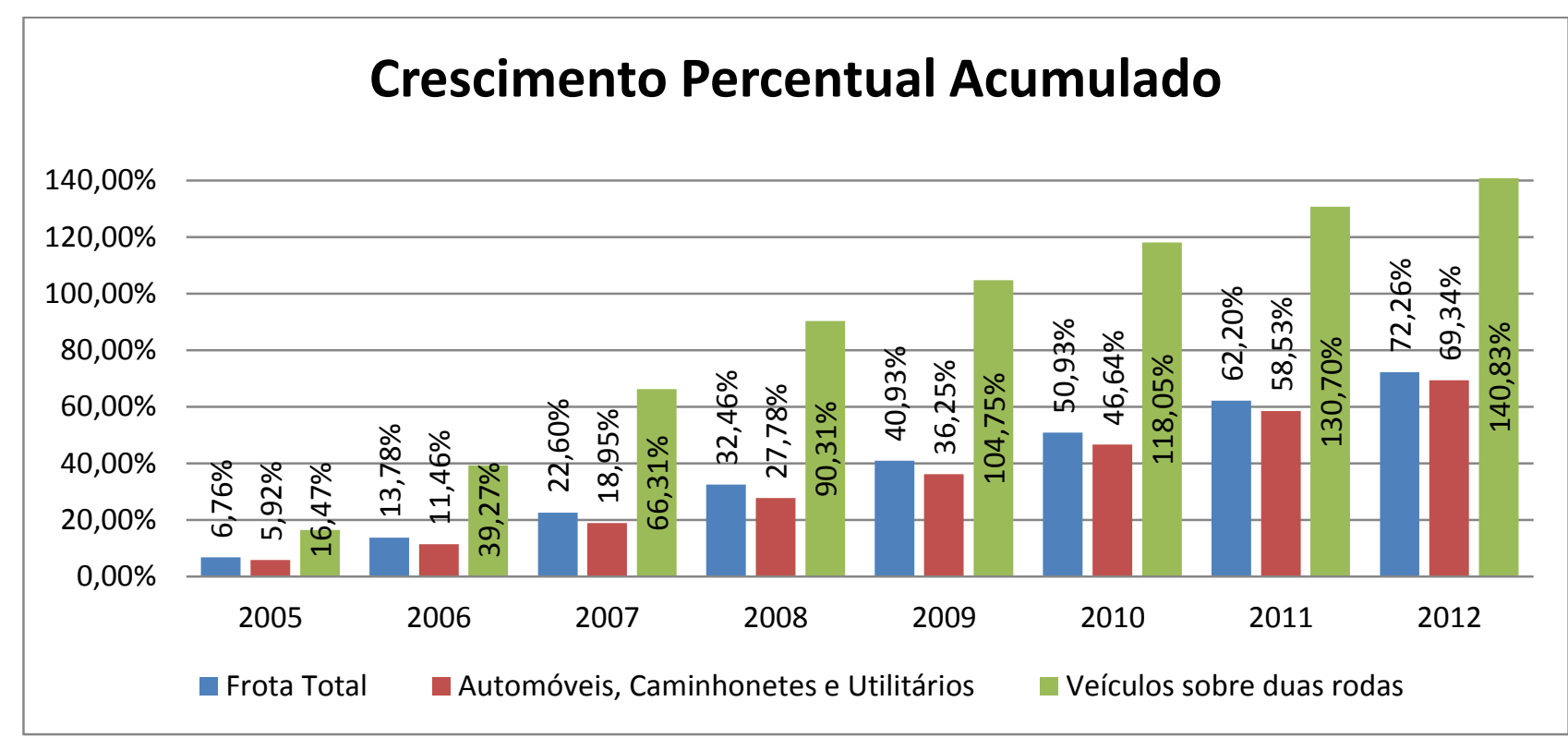

Figura 22 - Crescimento Percentual Anual Acumulado da Frota de Veículos na Cidade de Caxias do Sul

Grande parte do aumento da frota de veículos é formado por pessoas que migram do TPU para os modos individuais. Claro que esse aumento da frota não é totalmente proporcional ao aumento da exposição dos usuários, já que isso é dependente do uso, mas mostra uma tendência de que isso ocorra. Parte deste aumento se dá pela transferência de usuários do TPU para a moto, acarretando no aumento da acidentalidade devido ao risco inerente à motocicleta. A transferência para o automóvel também tem consequências sobre a acidentalidade, devido ao risco maior aos seus ocupantes e, principalmente, devido ao risco maior que infringe aos UVs. 


\subsection{Comparação do Tempo de Viagem}

Este parâmetro é, certamente, o mais importante a influenciar o processo de escolha modal. A migração dos usuários do TPU para os modos individuais, quase sempre, é resultado de uma busca por conveniência, representada na ordem por: tempo de viagem, frequência, conforto e segurança. Os congestionamentos pressionam também a transferência de um modo individual para outro; do carro para moto. Nos sistemas de transportes, de que se dispõem atualmente, há um aumento dos tempos de viagem e uma má prestação de serviços, de um modo geral. Muita coisa pode ser feita, no âmbito do ITS, pois embora exista tecnologia disponível, muitos ônibus ainda não possuem um sistema de localização em tempo real para auxiliar o usuário e, muitas vezes, acabam atrasando nos horários de pico.

Na Tabela 17 vê-se o levantamento do tempo de viagem feito para três modos motorizados, ônibus, automóvel e motocicleta. Foram utilizados os itinerários de algumas linhas do TPU do município de Caxias do Sul para o levantamento.

Tabela 17 - Comparação tempo de viagem entre ônibus, carro e motocicleta

\begin{tabular}{|c|c|c|c|c|c|c|}
\hline & & Ônibus & Carro & Moto & \multirow{2}{*}{ ônibus/carro } & \multirow{2}{*}{ ônibus/moto } \\
\hline \multicolumn{2}{|r|}{ Linha } & \multicolumn{3}{|c|}{ Tempo médio de viagem } & & \\
\hline L.04 & Cruzeiro & $00: 28$ & $00: 22$ & $00: 16$ & 1,27 & 1,8 \\
\hline L.10 & Panazzolo & $00: 22$ & 00:07 & 00:05 & 3,21 & 4,5 \\
\hline L.23 & Santa Lúcia & $00: 22$ & $00: 20$ & $00: 12$ & 1,10 & 1,7 \\
\hline \multirow{2}{*}{ L.25 } & Galópolis & $00: 25$ & 00:18 & $00: 14$ & 1,42 & 1,8 \\
\hline & & & & MEDIA & 1,26 & 1,77 \\
\hline
\end{tabular}

Na comparação do tempo de viagem do transporte coletivo versus modos individuais, das quatro linhas analisadas, uma delas apresentou uma diferença de tempo muito grande. Assim, para a composição do tempo médio na relação tempo de viagem ônibus/tempo de viagem veículos individuais, descartou-se o dado da L.10 Panazzolo.

Na comparação realizada, o transporte individual sempre se sobressai ao transporte público. Apesar da razão entre ônibus/carro não ser tão elevada, e estando dentro dos parâmetros considerados bons, muitas vezes o transporte coletivo enfrenta o problema de atrasos na partida e até "queima" de voltas. Essa falta de confiabilidade, agregada a um menor tempo de 
viagem, faz com que o usuário migre para os modos individuais. Na comparação ônibus/moto, a diferença de tempo é maior ainda, devido à característica da motocicleta em "furar" o congestionamento, ela apresenta o maior benefício em se tratando de tempo de viagem.

A variável tempo é uma das que mais impacta na escolha do modo de transporte, pois como diz o ditado popular: "tempo é dinheiro"; gastar mais tempo no trânsito significa menos tempo trabalhando, ou menos tempo com a família.

Diante os resultados obtidos, segue, na Tabela 18, um quadro resumo de todos indicadores listados na seção anterior com os resultados obtidos.

Tabela 18 - Resumo do Resultado dos Indicadores

\begin{tabular}{llcl}
\hline \multicolumn{2}{c}{ Grupo } & Indicador & Resultado \\
\hline I & Segurança & 1 & Aumento do Risco Relativo do UV \\
II & Motorizados & 2 & Diminuição do uso do TPU \\
& 3 & Aumento do Uso da Motoclita \\
II Comparação & 4 & Viagens de TPU são em média 26\% mais lentas que de \\
& & Tempo \\
Viagem & de & &
\end{tabular}

\subsection{Esforço do poder público para diminuir a acidentalidade}

Diante da diminuição do uso do TPU, e visando sempre a diminuição da acidentalidade, o poder público de Caxias do Sul desenvolve ações nas áreas da engenharia, esforço legal e educação para que essas situações sejam amenizadas. Seguem algumas medidas tomadas nos últimos anos. 


\section{Na área da Engenharia:}

- Análise e melhoria de pontos críticos: começou numa iniciativa do governo federal, em 2004, que consistia em treinar técnicos, nos principais centros urbanos, para que levassem esse conhecimento para suas regiões.

- Projetos para a criação de linhas troncais vinculadas a estações de transbordo, para melhorar o trânsito de ônibus na área central: bem como melhorar a frequência no bairro, diminuindo o tempo de espera do usuário e aumentando a distância percorrida pagando uma passagem. Projetos iniciaram em 2004, porém foram alterados e seu início ocorreu apenas em 2009, estando em fase de execução.

- O Plano de Mobilidade Urbana em fase de elaboração do termo de referência para realizar a licitação o mais breve possível.

- Legislação de Estudo de Impacto de Trânsito, desde 2007: essa medida visa analisar novos polos geradores de trânsito e definir ações para amenizar os impactos negativos em decorrência do aumento do tráfego no local.

\section{Na área do Esforço Legal:}

- Desde a criação da Lei Seca (2011), a Secretaria Municipal de Trânsito, Transportes e Mobilidade (SMTTM) atua em realização de blitz na noite, com frequência, para fiscalizar o uso de álcool entre os condutores. Em três anos do programa já foram abordados 64.207 veículos e, entre outras infrações, foram feitas 3.964 autuações de embriaguez.

\section{Na área da Educação:}

- Dentro da SMTTM, existe uma diretoria chamada escola de trânsito. Esta diretoria desenvolve programas de educação para jovens e adultos visando a melhoria da segurança no trânsito. Existem programas que iniciam nas séries iniciais, com realização de palestras, oficinas, e treinamentos nas escolas. Este programa tem o intuito de ensinar, desde cedo, as crianças a se portarem no trânsito como pedestres e 
ciclistas, e a aprenderem regras de trânsito que disseminam em casa com suas famílias. Existem também programas de auxílio às pessoas com traumas de direção. 


\section{CONCLUSÕES E RECOMENDAÇÕES}

Em virtude da melhora financeira de muitas famílias, a migração do transporte público para transporte individual ocorre de maneira natural, tendo em vista a qualidade ruim do serviço de transporte público e as comodidades do transporte particular. Nos últimos anos, essa migração tem ocorrido com maior frequência devido à facilidades de crédito e financiamentos e à desqualificação contínua do transporte público. Porém, esse aumento no uso do transporte particular foi muito maior do que a infraestrutura necessária para se ter um deslocamento satisfatório, e sempre será, pois o automóvel demanda espaço de forma irracional. Essa falta de infraestrutura tem causado o aumento de congestionamentos, diminuindo a velocidade média de deslocamento e causando a piora do transporte público, quando não há via exclusiva para o mesmo. O péssimo serviço de transporte público fez com que muitos usuários migrassem para a motocicleta, que possui benefícios equivalentes ao automóvel, mas, além disso, "dribla" os congestionamentos. Esse aumento no número de motocicletas gerou o aumento em acidentes, e geralmente o ferido é usuário deste modo, isto quando não envolve modos suaves. Analisando os dados de óbitos em Caxias do Sul, vê-se que, ao longo dos anos, existe uma curva ascendente de óbitos com motociclistas. Essa tendência é preocupante, pois nos afasta da meta da década da segurança no trânsito, bem como aumenta os custos públicos devido a internações, anos perdidos, pensões, socorro, entre outros.

Diante da mudança de paradigma, havia uma expectativa de melhoria na condição do UV, em relação ao UNV, em decorrência dos investimentos em engenharia, esforço legal e educação por parte do poder público. Em análise da condição do UV por meio da razão de prevalências, vê-se que esse grupo não teve a preocupação que os UNV receberam, visto que em todo o período analisado a prevalência do UV cresceu em relação ao UNV. A análise separada por grupo mostra que, para os UNVs, houve uma melhora na segurança, pois menos óbitos ocorreram. Parte disso se deve aos avanços tecnológicos, mas também é substancial a influência dos congestionamentos, que diminuem a velocidade de deslocamento e consequentemente a gravidade dos acidentes.

Já no caso do pedestre, especificamente, quando a via está congestionada, muitas vezes o pedestre atravessa a rua sobre a faixa de segurança, os automóveis param na faixa de retenção, e uma moto surgindo de trás não para e atinge o mesmo; o costume de não ficar preso em congestionamentos e filas acaba induzindo a esse tipo de acidente. 
A escolha da ferramenta TABNET do bando de dados Datasus se mostrou de análise fácil e rápida, porém o banco de dados coleta as ocorrências do município como um todo. Assim, não difere o local do acidente. Este trabalho avalia a acidentalidade urbana e pode haver uma distorção nos dados devido à falta da informação do verdadeiro local da ocorrência. As tentativas pela busca de outros dados apenas na área urbana foram exaustivas, e os órgãos de polícia ou de saúde alegaram não possuir os dados requeridos ou não poder disponibilizar os dados por serem sigilosos

A diminuição do IPKe no TPU é decorrência da migração dos usuários para outros modos de transporte. O aumento da frota, tanto de motocicletas como de automóveis, representa um aumento do uso destes modos, mesmo que o aumento da exposição não seja proporcional. O crescimento da população e a redução dos passageiros do TPU reflete essa realidade. Nos últimos anos, a transferência de usuários ocorre em grande parte para a motocicleta, impactando a segurança viária, aumentando assim os gastos públicos. Apesar de, na escola de trânsito do município, ter programas de educação voltados para o trânsito, não se verificou nenhum programa com foco na motocicleta.

Tendo em vista a mudança de paradigma, na qual o UV é o agente mais importante do sistema, viu-se um descaso com o mesmo. Esse descaso gera menor mobilidade, pois limita o usuário aos modos com mais proteção exterior e esses modos não estão ao alcance de todos. Sendo assim, o transporte se torna privilégio de alguns.

Essa tendência do uso da motocicleta, quando comparada com outras cidades do mundo, permite verificar que esse fenômeno do uso da motocicleta não é algo local, mas sim global. Os veículos de duas rodas, em geral, proporcionam mobilidade com custo baixo e um bom ganho de tempo, isso devido à eficiência desse modo em enfrentar congestionamentos, assim o usuário opta pela migração diante a ineficiência do poder público em melhorar o TPU.

Por fim, a análise do tempo de viagem ajudou a entender essa migração do usuário do TPU para os modos individuais. Mesmo sendo um conjunto de fatores que determinam a migração, como por exemplo, status e conforto, o tempo de viagem é um fator que influencia muito a decisão do usuário atualmente. Assim, proporcionar prioridades ao TPU e diminuir o tempo de viagem é uma diretriz fundamental para atrair mais usuários, diminuir a exposição e, 
consequentemente, melhorar a segurança.

A continuação do trabalho se dá pela continuação da busca em outros órgãos, tentando filtrar acidentes urbanos e rurais. Além disso, uma análise mais micro do entorno das linhas de TPU pode demonstrar a preocupação que o poder público tem em proporcionar acesso e segurança aos usuários de modos suaves, avaliando, assim, passeios públicos e ciclovias. Apesar de ter sido verificado um aumento maior da frota de motocicletas que a de automóveis, para se ter uma noção real do aumento do uso destes modos é necessário realizar contagens de tráfego e comparar com contagens antigas, assim poderá se comparar a mudança da exposição da motocicleta.

A grande constatação desta pesquisa é que ainda não é percebida, no cenário estudado, uma mudança de paradigma, como pode ser percebido ao longo das conclusões. Apesar da mudança na legislação, a mudança na mentalidade das pessoas demora a acontecer e a valorização dos modos suaves e do transporte coletivo, por parte dos cidadãos, tende a aparecer após um período de conscientização. Os investimentos atuais continuam a privilegiar claramente os modos motorizados e as formas tradicionais de pensar o problema da mobilidade urbana. Este fato, embora não seja uma limitação do trabalho ou da abordagem proposta, deve estimular pesquisas que esclareçam e promovam uma troca de paradigma real. 


\section{BIBLIOGRAFIA}

\section{AMERICAN ASSOCIATION OF STATE HIGHWAY AND TRANSPORTATION \\ OFFICIALS. HSM - Hightway Safety Manual. Washington, USA. 2010.}

ANTP. A Democracia da Desculpa. Newsletter Mobilidade e Conjuntura, v. 105, agosto de 2015.

ANTP. Série Cadernos Técnicos - Sistemas Inteligentes de Transportes. [S.1.]: [s.n.], v. 8, 2012. Disponivel em: <http://www.antp.org.br>. Acesso em: 23 Julho 2014.

ANTP; SPTRANS. Premissas para um plano de mobilidade urbana. São Paulo: [s.n.], 2012 .

ARRINGTON, G. B. Light Rail and the American City State-of-the-Practice for TransitOriented Development. 9th National Light Rail Transit Conference. [S.l.]: [s.n.]. 2012.

ASSUNÇÃO, M. A. Indicadores de Mobilidade Urbana Sustentável para a cidade de Uberlândia MG. 149 f. Dissertação de Mestrado do Curso de Engenharia Civil Universidade Federal de Uberlândia. Uberlândia. Brasil. 2012.

BASTOS, J. T. Geografia da Mortalidade no Trânsito no Brasil. 2011. 150 f. Dissertação de Mestrado do Curso de Engenharia de Transportes - Universidade de São Paulo, São Carlos, Brasil.

BASTOS, J. T. Um estudo dos acidentes de trânsito baseado na relação entre ocorrências e determinantes com ênfase na participação da motocicleta. 2008. Trabalho de Conclusão do Curso de Engenharia Civil Empresarial - Universidade Federal do Rio Grande, Rio Grande, Brasil.

BASTOS, J. T., Análise estratégica da segurança viária no Brasil: pesquisa de índices e indicadores. Tese de Doutorado do Curso de Engenharia de Transportes - Universidade de São Paulo, São Carlos, Brasil.

BRASIL. Código Brasileiro de Trânsito. Lei no 9.503, de 23 de setembro de 1997.

BRASIL. Diretrizes da Política Nacional de Mobilidade Urbana. Lei No 12.587, De 3 De Janeiro De 2012.

CHEN, C.; SKABARDONIS, A.; VARAIYA, P. Travel Time Reability As A Measure Of Service. 82nd Annual Meeting Transportation Reaserch Board, Washington, D.C., janeiro, 2003.

ELVIK, R. (1993). The effects on accidents of compulsory use of daytime running lights for cars in Norway, Accident Analysis and Prevention, 25, p. 685-694.

ELVIK, R. (1996). A meta-analysis of studies concerning the safety effects of daytime running lights on cars, Accident Analysis and Prevention, 28, p. 383-398.

ELVIK, R., VAA, T., HOYE, A. E SORENSEN, M. (2009). The handbook of road safety 
measures, Bingley, Emerald.

ELVIK, R; ERKE, A. e Christensen, P. (2009) Elementary units of exposure, Transportation Reaserch Record, 2103, p. 25-31.

EMBARQ. Recommendations for integrating safety into the planning, design, and operation of major bus routes. TRAFFIC SAFETY ON BUS PRIORITY SYSTEMS, JANEIRO 2015. ISSN ISBN: 978-1-56973-830-6.

EUROFORUM. Draft paper state of the Art of research and development in the field of urban mobility. The European Research Forum of Urban Mobility, 2007. Disponivel em: $<$ http://www.emta.com/IMG/pdf/SoA_FinalDraft_160207_FINAL.pdf $>$. Acesso em: 09 maio 2014.

EVANS, L. Traffic safety and the driver. Ed. Van Nostrand Reinhold. New York. 404, p. 1991.

EVANS, L. Traffic Safety. Science Serving Society, 2004. p. 444.

FERRAZ, A. C. P. et al. Segurança Viária. São Carlos, SP: Suprema, 2012.

FERRAZ, A. C. P.; TORRES, I. G. E. Transporte Público Urbano. 2ª ed. São Carlos: RiMa, 2004.

FERREIRA, F. A. et al. Investigação de Acidentes de Trânsito com Vítimas Fatais na

Cidade do Rio Grande. X Mostra de Produção Universitária. Rio Grande: [s.n.]. 2011.

FRIDSTROM, L., IFVER, J., INGEBRIGTSEN, S., KULMALA, R. E THOMSEN, L. K. (1995) Measuring the contribution of randomness, exposure, weather, and daylight to the variation in road accident counts, Accident Analysis and Prevention, 27, p. 1-20.

GEHL, J. Cidade Para Pessoas. [S.1.]: [s.n.], 2012.

GOODCHILD, M.F. Citizens as sensors: the world of volunteered geography. GeoJournal 69 (4): 211-221. doi: 10.1007/s10708-007-9111-y, 2007.

GOVERnO BRASILEIRO, [Online], Ministério da Saúde: DATASUS, Disponível em: http://www2.datasus.gov.br/DATASUS/index.php. [Acessado em abril de 2014].

GTZ, S. I.-C. Cycling-inclisive policy development: a Handbook. Utrecht: [s.n.], 2009. JACOBS, J. Morte e Vida de Grandes Cidades. 3 ${ }^{\text {a }}$. ed. [S.1.]: WMF Martins Fontes, 1961.

HAUER, E. Can one estimate the value of life or is it better to be dead than stuck in traffic? Transpn. Res - A. vol. 28a. No 2. p. 109 - 118. 1994.

Highway Capacity Manual - HCM 2010, Transportation Research Board, National Research Council, Washington, D. C., 2010.

INSTITUTE, V. T. P. VTPI. VTPI. Disponivel em: <http://www.vtpi.org>. Acesso em: 2015. 
ITDP. Manual de BRT - Bus Rapid Transit - Guia de Planejamento. [S.1.]: [s.n.], 2008.

IBGE. Infográfico: Evolução da populacional e pirâmide etária. Disponível em: $<$ http://cidades.ibge.gov.br/painel/populacao.php?lang=\&codmun=430510\&search=riogrande-do-sul|caxias-do-sul|infogr\%E1ficos:-evolu\%E7\%E3o-populacional-e-pir\%E2mideet $\%$ E1ria $>$. Acessado em $1^{\circ}$ de fevereiro de 2015.

JACOBS, J. Morte e Vida de Grandes Cidades. 3a . ed. [S.1.]: WMF Martins Fontes, 1961.

KING, M. J., WOOD, J. M., LACHEREZ, P. F. E MARSZALEK, R. P. (2010) Optimism about safety and group-serving interpretations of safety among pedestrians and cycling in relation to road use in general and under low light conditions, Accident analysis and Prevention, p. 154-159.

MACHADO, L. Índice de Mobilidade Sustentável para avaliar a qualidade de vida urbana. Estudo de caso: Região Metropolitana de Porto Alegra -RMPA. 2010. $173 \mathrm{f}$. Dissertação de Mestrado do Curso de Planejamento Urbano - Universidade Federal do Rio Grande do Sul. Porto Alegre. Brasil

MEDRONHO, R. A. Epidemiologia. Editora Atheneu. São Paulo-SP, 2007.

MIETTINEN, O. S. Theoretical epidemiology. 1985. 359 f. Wiley, New York, USA.

MINISTÉRIO DAS CIDADES. Manuel de BRT (Bus Rapid Transit): Guia de Planejamento. Secretaria Nacional de Transportes e da Mobilidade Urbana. 2008. Brasília, Brasil.

MINISTÉRIO DAS CIDADES. PlanMob Caderno de referências para Elaboração de Planos de Mobilidade Urbana. Secretaria Nacional de Transportes e da Mobilidade Urbana. 2007. Brasília, Brasil.

MINISTÉRIO DAS CIDADES. Plano Nacional de Redução de Acidentes e Segurança Viária 2011-2020. Brasília, p. 23. 2010.

NILSSON, G. Traffic Safety Dimensions and the Power Model to Describe the Effect os Speed on Safety. Tese de Doutorado. 2004. Lund Institute os Tecnology. Suécia.

OLIVEIRA, A. M. et al. O impacto do crescimento da frota no risco relativo no trânsito em uma cidade de porte médio. XVI ENAPET. [S.1.]: [s.n.]. 2011.

OLIVEIRA, A. M. Avaliação do risco relativo enfrentado pelos usuários suscetíveis do sistema de trânsito em um ambiente em transformação: caso Município de Rio Grande. EE-FURG. Rio Grande - RS. 2013.

OTTE, D.; JÄNSCH, M.; HAASPER, C. Injury protection and accident causation parameters for vulnerable road users based on German In-Depth Accident Study GIDAS. Accident Analysis \& Prevention, Hanover, v. 44, p. 149-153, Janeiro de 2012.

PRATO, C. G.; GITELMAN, V.; BEKHOR, S. Mapping patterns of pedestrian fatal accidents 
in Israel. Accident Analysis \& Prevention, v. 44, p. 56-62, Janeiro 2012.

PREFEITURA MUNICIPAL DE CAXIAS DO SUL. Plano de Diretor Municipal. Caxias do Sul. Brasil.

RICHARDSON, A. J. Some Evidence of Travelers with Zero Value of Time. Transportation Research Record, v. 1857, p. 107-113, jan 2003. ISSN 03-2588.

ROMÃO, M. N.; DE CAMPOS, C. I. Análise comparativa dos bancos de dados disponíveis no Brasil sobre vítimas fatais em acidentes de trânsito. $18^{\circ}$ Concresso Brasileiro de Transportes e Trânsito. Rio de Janeiro: [s.n.]. 2011. p. 8.

SILVEIRA, I. M. et al. Avaliação da mobilidade sustentável baseada no risco relativo sobre o usuário vulnerável. $6^{\circ}$ CONGRESSO LUSO-BRASILEIRO PARA PLANEAMENTO URBANO, REGIONAL, INTEGRADO E SUSTENTÁVELL. Lisboa: [s.n.]. 2014.

TRINDADE, R. E. Jr. Procedimento para o acompanhamento de vítimas de acidentes de trânsito. Dissertação de Mestrado. COPPE-UFRJ. 1988.

VALENTE, A. M., NOVAES, A. G., PASSAGLIA, E., VIEIRA, H. Gerenciamento De Fretes E Frotas. $3^{\text {a }}$ Ed., São Paulo: Cengage Learning, 2016.

VIEIRA, H. Avaliação de medidas de contenção de acidentes: uma abordagem multidisciplinar. Tese de doutorado. PPEP-UFSC. Florianópolis-SC. 1999

VIEIRA, H., BASTOS, J. T., CAMARGO, K. R. E VALENTE, A. M. (2009) Um estudo do uso de motocicletas no município do Rio Grande (RS): aspectos gerais e acidentológicos, $\mathbf{X V}$ CLATPU - Congresso Latino-americano de Transporte Público e Urbano. Buenos Aires, 2009.

VIEIRA, H., GOLDNER, L. G., VALENTE, A. M., BASTOS J. T. E CAMARGO, K. R. (2008) A expansão do uso de motocicletas em cenários do sul do Brasil: uma abordagem analítico-retrospectiva, XXII Congresso da ANPET - Associação Nacional de Pesquisa e Ensino de Transportes. Fortaleza - CE.

VIEIRA, H. et al. Um estudo do uso de motocicletas no município de Rio Grande (RS): aspectos gerais e acidentológicos. XIV CLAPTU - Cogresso Latino-americano de Transporte Público e Urbano. Rio de Janeiro: [s.n.]. 2007.

VIEIRA, H. et al. Avaliação da mobilidade urbana a luz do novo paradigma: um estudo da prevalência de agravos entre usuarios vulneráveis e não vulneráveis. XVIII Congreso Latinoamericano de transporte público. Rosário: [s.n.]. 2014.

VTPI. Victoria Transport Policy Institute, 2013. Disponivel em: 〈http://www.vtpi.org/>. Acesso em: 14 agosto 2015.

WEI, V. F.; LOVEGROVE, G. Sustainable road safety: a new neighbourhood road pattern that saves VRU lives. Accident Analysis \& Prevention, v. 44, p. 140-148, Janeiro 2012. 
ZAMBON, F; HASSELBER, M. Socioeconomic differences and motorcycle injuries: Age at risk and Injury severity among Young drivers. Accident Analysis and Prevention, v. 38, p 1183-1189, 2006. 